\title{
AANTEEKENINGEN BIJ HET AGASTYAPARWA.
}

\author{
DOOR
}

Frof. Dr. J. GONDA.

In aansluiting op de meer samenvattende beschouwingen van de Inleiding bespreken de 2 e Aanteekeningen een aantal bijzonderheden uit den inhoud van het werk. In de eerste plaats zijn vele passages en uitdrukkingen met Voor-Indische parallellen vergeleken. De citaten uit Sanskrit werken zijn niet steeds vertaald; dit scheen mij niet noodzakelijk, daar zij die deze taal in het geheel niet verstaan tot de lectuur van het Agastyaparwa wel niet zullen overgaan. Er is evenwel zorg gedragen tevens de voor niet-philologen wenschelijke toelichting zoo beknopt mogelijk te geven, meestal slechts door middel van verwijzingen naar betrekkelijk gemakkelijk bereikbare publicaties; van Sanskrit teksten zijn, als het kon, de meest toegankelijke bij voorkeur geciteerd. Bij een aantal passages hadden de aanteekeningen tot korte verhandelingen kunnen uitdijen; ook daar heb ik mij beperkt; het lijkt mij evenwel zeer gewenscht, dat het door onzen tekst geboden materiaal met stof, ontleend aan andere, Voor-Indische en Javaansche, bronnen, in afzonderlijke artikelen worde verwerkt.

\section{Mei '33.}

p. 343-1. Het werk vangt aan met een strophe van 68 syllaben, d.i. $4 \times 17$ (atyaști), welke niet in het Oud-Javaansch is vertaald en grootendeels zeer corrupt is. Ik heb daarom van voorstellen tot emendatie, in een geval als dit, zoolang, althans mij, de strophe niet van elders bekend is, een gewaagde onderneming, afgezien.

Jagadguru, h.1. Çiva. Men lette ook op Bhairava, even verder.

Drḍhasyu, de zoon van Agastya en Lopāmudrā, komt in de Indische purāna-literatuur slechts zelden voor. Elders heet hij Idhmavāha. Van beide namen bestaan varianten: Dṛ̣hāsya, Dṛ̣hayus, Dṛ̣hadyumna; Vidhmavāha, Indrabāhu. Zie Pargiter, Anc. Ind. hist. trad., p. 239. Vgl. ook O.-J. Bmḍ. Pur., p. 80, 16; zie mijn aant. Over Lopāmudrā zie de Inl., p. 344. Zie ook Bāṇa, Kād. p. 43 (N.S.). 
-8. hana sira, etc.; deze eerste regels zijn opgenomen door Dr. Poerbatjaraka, Agastya in den Archipel, pp. 39 vlg. Dit citaat bevat eenige slordigheden, afgezien ervan dat het slechts op één handschrift berust (p. 39, n. 3). In het Sanskrit-citaat lijkt mij slechts ${ }^{\circ}$ prabhāva (ook ${ }^{\circ}$ prabhava is mogelijk) zin te geven. Of Poerbatjaraka gelijk heeft met z'n lezing tumonton (tumunto in den tekst?) betwijfel ik.

$\mathrm{Al}$ is het denkbaar, dat hier van A. gezegd zou worden, dat hij den weg van de zon wilde aanschouwen, men verwacht toch een woord voor toegankelijk maken.

-12. Yavadvipaikay ${ }^{\circ}$. Poerbatjaraka interpreteert het overgeleverde met: yavadwipeka (sic) yogiçcwara, en vertaalt: „hij (Agastya) was de eenige heer der yogins van het eiland Java". Waarschijnlijk heeft hij dus an Skt. cka (niet Jav. $i k a$ ) gedacht. Ook mij lijkt dit de goede opvatting; echter zou ik ekayogīcvara als compositum willen nemen: ,,voortreffelijke, eenige, voornaamste yogiçvara”, vgl. uitdrukkingen als : ekavira ,eenige held”, b.v. Mbh. 4, 1912; ekanata, ,,voornaamste tooneelspeler”, ckacakravartin, ,,eenig alleenheerscher”, ekadhanurdhara (P.W. I, 1070 vlgg.). Een $e$ der hs. mag als -aiworden opgevat.

-13. makakṣctra, (over de spelling kṣyetra in hss. vgl. Wulff, Wirāțaparwa, pp. 127 ; 200). Kșetra; over de beteekenis vgl. Vogel, Bijdr. Kon. Inst., 74, p. 203, n. 1; Poerbatjaraka, Agastya, pp. 40; 69; Bosch, T. B. G., 67, p. 469 , ,die de kṣetra uitmaakt van het geheele eiland Java".

sira ta makatwanak nira lezen de handschriften; Dr. Poerbatjaraka (voor zijn emendatie-poging zie het crit. app.) vertaalt: die geëerd werd (conjectuur) door zijn kinderen. Dit meervoud lijkt mij wegens het onmiddellijk volgende sira ta matakwan, waarmee toch slechts Dṛhhasyu bedoeld is, die verder alleen optreedt als ondervrager, onjuist. Bovendien is ons het nageslacht van Agastya niet bijzonder duidelijk. In het Mbh. 3, 8577 vlgg. wordt de geschiedenis van A. en Lopāmudrā verhaald: zij wil een zoon, en wel één zoon hebben; vgl. vs. 8637; Agastya willigt haar wensch in en begeeft zich naar het woud. Na zeven jaren brengt ze een zoon voort: Dṛ̣hasyu, even verder Idhmavāha geheeten, omdat hij brandstof voor het offervuur (idhman) naar het huis van z'n vader bracht. Dezelfde persoon heet hier dus Dṛ̣hasyu en Idhmavāha. Afgezien van de varianten, die van beide namen voorkomen (zie boven), blijkt echter uit een plaats als Bmọ. Pur. 1, 32, 119: Agastyo 'yo Dṛ̣̂hāyuç ca Vidhmavāhas tathaiva ca, duidelijk, dat D. en V. (=I.) twee verschillende 
personen zijn; dit ook elders, zie Pargiter, t.a.p., die D. als vader van I. beschouwt, omdat de laatste wel Dārḍhacyuta heet en Dṛ̣̂hacyuta $=$ Dṛ̣hasyı zal zijn. Vgl. ook O.-J. Bmḍ. Pur., p. 80, 16: D., I., Dyumna; zie de aant., p. 260. - Dr. W. Germann, de uitgever van Ziegenbalg's Genealogie der malabarischen Götter, Madras, 1867, teekent op p. 229 aan: Beider (n.l. van Ag. en Lop.) Sohn ist Sagaren; is dit een andere traditie?

-16. Brahmānda en wat zich daarbij aansluit, vgl. Bmḍ. Pur., p. 55, 17 vlgg., en de aanteekeningen daarbij. Zie ook de Inleiding tot het Agastyaparwa.

1. 344-2. Kälägni; beschrijvingen van den pralaya vindt men b.v. Viṣnu Pur. 1, 3, 22 vlgg., en in een aantal andere teksten; vgl. W. Jahn, Das Saurapurānam, Habilitationsschrift Zürich, 1909, p. 84, n. 2. Kālägni, meermalen in Oud-Jav. teksten voorkomend en meestal weergegeven met ,het vuur van den Doodsgod, verdelgend vuur", is een geweldig monsterachtige vuur-gestalte, die bij den pralaya optreedt en alles verzengt en verbrandt. Het Vãyu Pur. geeft, 30, 122 vlgg., een bij Wilson-Hall, Vishṇu Purāṇa, I, pp. 128 vlg. vertaalde beschrijving van een op Kālāgni gelijkend monster. Vaak vinden we de voorstelling, dat Çiva zelf als Kālāgni optreedt; zie b.v. Viṣnu Pur. 6, 3, 24 tatah Kālāgnirudro 'sau bhūtvā sarvaharo Harị̣ | Çeșaniçvāsasaṃhhūtạ̣ pātālāni babhasty adhạ̣ ||. Zie ook Jahn, t.a.p., p. 174, s.v. Elders is hij een afzonderlijk wezen, door Rudra's en miljoenen groepgoden omstuwd, luisterend naar Çiva's bevelen; zoo b.v. Saura Pur., Adhy. 57.

-4. Sadāçiz' a, een ook in het Oud-Jav. wel voorkomende (K. B. W. III, 158) benaming van Çiva. Vgl. 'n citaat uit de Korawāçrama bij Pigeaud, T. P., p. 41, en Goris, Bijdr. O.-J. Bal. Theol., passim (vgl. p. 167). De Çaiva-Siddhānta leert: Heer van ontstaan en vergaan der wereld is de hoogste God, Çiva. Ten tijde van het ontstaan der wereld laat hij zijn Çakti in werking treden en zich in vijven verdeelen, Çiva, Çakti, Icchāçakti, Kriyāçakti, Jñānaçakti. Deze zoo ontvouwde Çakti laat hij dan inwerken op de eeuwig voorhanden oerstof, de Māyā, waarin de wereld als kiem aanwezig is. Door Çiva en Çakti krijgt de oerstof leven; door Icchāçakti wil Çiva dat de wereld zich uit de oerstof ontwikkelt, enz. Uit de verbinding van Çakti en Māyā ontstaan de vijf Çuddha-tattva's, waarvan de eerste, Nāda = Klank, en de tweede, Vindu = Vorm, zich verbinden, tengevolge van de werking van de Icchāçakti; daarbij ontstaat de derde Ç.-t., n.1. Sādākșya (Tam. Sātākkiam, vgl. Schomerus, t.a.p., p. 442, 
s.v.), de natuurkracht van het ontstaan, deze dient als standplaats en lichaam van Sadāçiva. Sadāçiva is een van de negen gestalten, die Çiva aanneemt, manifestaties door welke hij werkt (Çiva, Çakti, Nāda, Vindu, Sadāçiva, Maheçvara, Rudra, Viṣnu, Brahmā). De eerste is Çiva als de intelligentie, die het lot der zielen en den weg van hun verlossing kent, Çakti is de energie, krachtens welke hij de zielen verlossen kan (daarom laat hij Çakti uit zich uitgaan en in werking treden). In Nāda- en Vindu-gedaante geeft hij de oerstof de mogelijkheid der ontwikkeling. In de gedaante van Çadāçiva wil hij de verlossing der zielen en door middel van de uit Mãyā ontstaande producten werkt hij aan deze verlossing. Dit is het vijfde van Çiva's vijf hoofdwerken, het werk der Genade of der Verlichting, door de Icchāçakti verricht. Vgl. H. W. Schomerus, Der ÇaivaSiddhānta, eine Mystik Indiens, Leipzig, 1912, pp. 148; 74. Elders wijkt de voorstelling hiervan af. Zoo b.v. bij Shrīyukta Baradā Kānta Majumdār, in de Introduction op A. Avalon's Principles of Tantra, II (Londen, 1916), p. XXXI : In ieder van zeven kosmische machtscentra (Loka's) staat aan het hoofd een heer met een vrouwelijk gedachte „Macht”, in de eerste, Satyam, de hoogste heer, Paraçiva met Adyāçakti, enz.; in de derde, Janah, Sadāçiva, genoemd Ardhanarīçvara, met Mahāgaurī. In Tantra's is er herhaaldelijk sprake van Sadāçiva, soms (b.v. in het Mahānirvāṇa Tantra) is hij, in een tweegesprek met Devī, de verteller.

Ook in Purāṇa's is wel sprake van Sadāçiva, b.v. Bhāg. Pur. 8, 7, 19, bij het te voorschijn komen van het vergif Hālāhala: bhītāh prajā dudruvur ..... ārakṣyamāṇāh çaraṇạ̣ Sadāçivam, waar Burnouf vertaalt : ,auprès du Dieu toujours heureux”. In het PadmaPur. treedt deze figuur zelfs als verteller van een onderdeel op (,through a machinery borrowed from the Tantras”, Wilson-Hall, Vishṇu Pur., I, p. XXXII). De naam is desnoods te vertalen met „,de steeds gunstig gezinde, - weldoende” (,the Ever-Auspicious”, Avalon, bij Mahānirv. T., vert., 1, 14; Goris, Bijdrage, p. 28: „Altijdtegenwoordige Çiwa",?).

nirātmakasaiabhäwa, ,zonder individueele existentie”.

-5. sakala-niṣkala; s. $(\times$ n. $)=$ materieel. Zie ook Goris, Bijdrage, p. 92, n. 1. Vgl. b.v. ook Mbh. 13, 16, 8 (= =13, 1044) niṣkalạ̣ sakalạ̣ Brahma nirgunam gụnagocaram.

Çarzua, vgl. ook Bmụ. Pur., p. 56, 16, e.a.

-6. caturbhüta, de puranische leer is: 5 bhüta's, elementen: de hier genoemde en het water, āpah. Zie ook O.-J. Bmọ. Pur., p. 55, 17. 
De Boeddhisten nemen vier mahābhūta aan : aarde, water, vuur, wind.

De volgorde is hier: de grove elementen, het ei, Brahmã en Viṣnu. Dan ontstaan door B.'s toedoen de Prajāpati's, Sanaka enz. en Vyāsa(!), daarna de brahmarși's, Manu's en pitaraḥ; afwijkend dus van het O.-J. Bmọ. Pur., p. 54, 27 vlgg. (in 't kort: Acta Or. 11, 223 vlg.).

-12. Sanaka enz., Bmọ. Pur. p. 55, 26, vlgg., met de aant. Men vergelijke beide passages!

-19. tatah, vgl. b.v. Bmọ. Pur. 1, 5, 74 ; 1, 9, 22 ; Linga Pur. 70, 186, waar (Li. Pur.) prānāa Brahmā 'sṛjad Dakṣam cakṣurbhyām ca Marīcinam | Bhṛgus tu hṛdayāj jajñe ṛ̣iḥ salilajanmanạ ||. Zie ook Vā. Pur. 9, 92 mānasaç ca Rucir nāma vijñeyo Brahmaṇah sutah | prāṇāt svād asṛjad Dakṣaṇ cakṣurbhyāṇ ca Marīcinam. Vgl. de aant. bij Bmọ. Pur. p. 57, 11 en de geheele passage.

-24. ahamkāra ${ }^{\circ}$; opmerkelijk is, dat Nilalohita in dit verband genoemd wordt; men vergelijke Vāyu Pur. 9, 95: abhimānātmakạ̣ bhadrạ̣ nirmame Nilalohitam; waarnaast reeds in het Bmọ. Pur. 1, 9, 23 : $\mathrm{abh}^{\circ}$ Rudram nirmame nilalohitam.

-29. Atri, het Vā. Pur. gaat verder: çiraso 'ngirasạ̣ caiva çrotrād Atrim tathaiva ca | Pulastyạ̣ ca tathodānād vyānāc ca Pulahạ̣ punạ̣ | samānajạ̣ Vaçișțhạ̣ tu, apānān nirmame Kratum.

345-4. Nahan. De brahmarși's of prajāpati's zijn hier dus: Dakṣa, Marīi, Ruci, Nìlalohita, Bhṛu, Atri, Angira, Pulaha, Kratu, Wasiștha, tien in getal; het Bmọ. Pur. geeft 9 (p. 56, 8, en Aant.) : Pulastya, aldaar genoemd, ontbreekt hier; Ruci (cf. Skt. Bmọ. Pur. 1, 9, 20; 21; Vā. Pur. 9, 92) en Nỉlalohita (Skt. Bmọ. Pur. 1, 9, 23; Vā. Pur. 9, 95) komen daar niet voor (vgl. p. 58, 17!); voor N. vgl. echter Rudra, Bmḍ. Pur. p. 57, 13, waarbij verg. Skt. Bmḍ. Pur. 1, 9, 23. Genoemde Skt. teksten hebben echter niet steeds dezelfde opvatting. Zie Pargiter, Anc. Ind. hist. trad., p. 185, met n. 1. - Anigira komt hier dus uit 't hoofd, afwijkend van Bmọ. Pur. p. 57, 14 (çirasah, Skt. Bmọ.- en Vā. Pur.), Pulaha uit den prāṇa bāyu, anders dan Bmọ. Pur. p. 57, 15.

-5. pañcaprāna. hier eigenaardig gebruikt. De prāṇa's zijn meestal 5 in getal: prāṇa, apāna, samāna, vyāna, udāna (lichaamswindstroomingen; Lebenshauche); zoo b.v. in 't Bmḍ. Pur.; hier zijn er slechts drie genoemd (vgl. K. B. W. IV, 291); kan dit er op wijzen, dat er twee zijn uitgevallen (Pulastya uit den udāna) en in de war geraakt (Dakșa en Pulaha)? Of is bedoeld ,,de vijf zintuigen?". Over de vijf prāṇa's Caland, Z. D. M. G. 55, p. 261 vlg.; Garbe, Sāṃkhya- 
Phil."2 p. 318 en daar genoemde literatuur, Tuxen, Yoga, p. 86; e.a. bv. Jolly, Medizin, p. 40. - Zie ook Kats, Sang hy. Kam., p. 168.

-6. Caturdaça-Manu: zeer korte overgang! Bij deze passage vgl. Bmḍ. Pur. p. 113, 1 sqq. De namen zijn voor een deel gemakkelijk te herkennen; de latere hebben geleden: pañca-Sāwarṇi heeten 8-12, Bmọ. Pur. p. 113, 12. Swārocima kan een reeds ,,voor-Javaansche” fout zijn (Wuiff, Wirăta-parwa, p. 50). Tawasa: vgl. Bmḍ. Pur., bij p. 113, 5. Recaka < Raivata, een zeer veelvuldige fout; derhalve verbeterd. Waiwaswata is (vgl. r. 11) verbeterd, ofschoon men steeds aan Dewa $^{\circ}$ heeft kunnen denken (voor $w>$ d, b.v. Wirāțap., p. 86, 17). Rohita is ook Hariv. 468 de naam van den negenden Manu, Dakṣa-Sāvarṇi. Lohita's zijn een klasse goden onder den twaalfden Manu; zie Viṣnu Pur. 3, 2, 33. Over de verdere namen: de aant. bij Bṃ̣. Pur. p. 113, 12; Wilson, bij Vi. Pur., in Wilson-Hall, III, p. 25. De namen $P$. en $S$. ken ik niet van elders.

-16. caturyugāni ; is caturyugāni hier op te vatten als ,die vier Weltalter in sich schliessend"? (vgl. Raghuvamça, 10, 23). Over de lengte van een manvantaram enz. mijn aant. bij Bmḍ. Pur. p. 58, 1. Verwisseling van -e en -aṇ b.v. Wirāțap., pp. 24, 27; 56, 9; van k(kh) en n: Wulff, Wirătap., p. 178.

-22. pira kari anak. Over de kinderen van Dakșa heb ik in de Inleiding gesproken; men zie aldaar, pp. 356 vlgg. Hier nog eenige bijzonderheden.

-27. Prajāpati: elders Dharma.

Onder de namen van de kinderen dezer 13 dochters zijn enkele, die afwijken: Dhṛti met Wedhṛti, welke naam mij in dit verband onbekend is. Vaidhṛti of -a is in het Bhāg. Pur., 8, 13, 25, de naam van Indra in den elfden Manvantara, elders (ibid., 8, 1, 29) de naam van een klasse goden, kinderen van Vidhrti. - Kuntimān, elders Lobha of Lābha, is mij verder niet bekend. - De namen van de kinderen van Kriyā zijn gelijk aan de in Vāyu Pur. 10, 34 genoemde. - Voor Pramiti hebben andere teksten Apramāda, b.v. Bmḍ. Pur. p. 59, 2; zie de aant. Ofschoon Pramiti voorkomt (in ander verband, b.v. Vā. Pur. 98, 110), zou men hier Pramati kunnen veronderstellen. - Weçaya, elders, b.v. Skt. Bmụ. Pur. 1, 9, 61, Vyavasāya, waarvan onze vorm een verbastering kan zijn. - Soma, elders Kṣema, waarsch. verknoeid ( $\mathrm{kṣ}>\mathrm{s}$ zeer veelvuldig, e $>0$ ). Çuta zal uit Sukha verknoeid zijn, Yaça(h) is elders de dochter van Kirti; ook het Oud-Jav. Bmọ. Pur. wijkt af (p. 59, 4). De mededeeling over de zoons van Kïrti is eveneens eigenaardig. 
p. 346-16. kalinanya. De volgende namen (voor de volgorde: aant. bij Bmọ. Pur. p. 58, 22) : Smuti < Smṛti ; Parā ontbreekt elders. Swaya staat voor Svāhā.

-20. kuměmit antiganya: mij niet van elders bekende uitdrukking.

-22. Dakșena, de lezing is zuiver gissing.

-23. bhațāra, niet mogelijk te beslissen of $\mathrm{x}$ of $\mathrm{y}$ de juiste lezing heeft ; vgl. Bmạ. Pur. pp. 59; 60 passim.

-24. Sahasra-rudra, Bmḍ. Pur. p. 59, 26.

Khyāti met man en nakroost, Bmḍ. Pur. p. 60, 17 sqq. Ook hier een afwijkende naam voor Çrī's tweede kind: Açwa; soms wordt Açwa als zoon van Dakṣa genoemd (zie Wilson-Hall, Vi. P. I, 103). Het is echter zeer wel mogelijk, dat de verdere kinderen van Çrī „kuda ya wih” (Bmọ. Pur., p. 60, 23), ,divyacārinahạ | ye vahanti vimānāni devānāṃı” (Vā. Pur. 28, 3), hieronder verborgen zijn.

-29. Pundarika à enz., Bmḍ. Pur. p. 60, 31 sqq. Over Mārkanḍeya is onze tekst uitvoeriger. Wukir Damalun, zie K. B. W. II, 520; Pigeaud, T. P. p. 214 (citaat); vgl. ook p. 347, s.v.

1).347-3. Dhūmrānū, Bmọ. Pur. 60, 29 Dhūmrā (de uitgang -ānī vaak bij vrouwennamen, zie b.v. Whitney, Skt. Gr., $§ 1223$ b); er komen varianten voor; zie aant. ald. Vedaçiras ook in Skt. teksten, Oud-Jav. Bmọ. Pur. wijkt af.

-5. nihan, hier van het voorafgaande.

-6. Sambhūti, etc.: Bmḍ. Pur. p. 61, 7. - Krmi etc., elders vier namen, zie de aant. ald. r. 8; Krmi herinnert aan Krsți, Acinti aan Apaciti (Vã. Pur. 28, 9c). Ook Pazuaça (hss. F H) is eigenaardig; bedoeld is Parvaça; het woord is, daar vele varianten voorkomen, niet veranderd; zie ad Bmọ. Pur. p. 61, 11.

-9. Suddhanwuā voor Sudhāmā. Parwaçā zal de vrouw van Pawaça zijn (in Skt. teksten is Parvaçā de vrouw van Parvaça, zie Bmọ. Pur. 1, 11, 15 e.a.). Wellicht is er in onzen tekst iets verloren gegaan, n.l. sà̉ Paźą̧a makastrī voor den naam van de tweede vrouw. Bij de namen van de kinderen vgl. ibid. 1, 11, 16: sutau | Yajurdhāmam ca - Stambhakāçyapam; vgl. echter Oud-Jav. Bmọ. Pur. p. 61, 13.

-13. Siñ̄bālì en $K u h u$, elders zes kinderen, doch geen toelichting; Kuhu naast Kuhū (b.v. Vā. Pur. 28, 15).

-17. Prīti, vgl. Bmḍ. Pur. p. 61, 26; daar wsl. Datoni en nog twee zoons Dewabāhu en Hatimāna, die hier dochters zijn ; bij den laatsten naam b.v. Vā. Pur. 28, 23 svasā yavīyasī teșām Sadvatĩ nāma viçrutā.

-20. Sujainghā. In 't Vā. Pur, en Skt. Bmụ. Pưr. (28, $24: 1,11,29)$ 
Sujainghī. - Rāma doodide inderdaad Subāhu (vgl. b.y. Rām. 1, 19; 30; Viṣnu Pur. 4, 4, 42; p. 316 bij Wilson-Hall, III).

-23. Kșamā (verbeterd; zie crit. app.), Bmḍ. Pur. p. 62, 1. Ambariwān, ald. p. 114, 4; vgl. bij p. 62, 2. De derde naam staat in de hss. y + B voor Sahiṣnu. - Elders meer over deze familie. - Parā wordt hier niet genoemrl. Sannati, enz. Bmḍ. Pur. p. 62, 9. Over de Vālakhilya's is ook 't Skt. Bmọ. Pur., 1, 11, 37, uitvoeriger: Arunasyāgrato yānti parivārya Divākaram; 't Oud-Jav. Bmọ. Pur. niet; zie p. 62, 10 en de aant. De eene zuster heet ook Bmḍ. Pur., 1, 11, 38, Satyavati ; de andere naam wijkt af.

-30. Anasūyā, Bmọ. Pur. p. 61, 22. Pañcâkalmașa zal te lezen zijn; niet als eigennaam van één persoon op te vatten: vgl. Bmọ. Pur. 1, 11, 22 ; Vā. Pur. 28, 18: Anasūyā vijajñe vai pañcātreyān akalmașān; andere teksten spreken van: jajñe putrān akalmașān (vgl. Kirfel, P. P., p. 42, 6). - Bij Satyadewa is in hs. A aangeteekend: Satyanetra; zoo ook Bmc̣. Pur., p. 61, 23 en in Skt. teksten. Voor den tweeden naam elders Hawya. Rawisuta slaat op Çanaiçcara, de planeet Saturnus, een zoon van den Zonnegod, Buddha op het dan als Çākya gelezene Sakya. De vijfde zoon, Soma, ontbreekt, hoogstwaarschijnlijk uitgevallen.

p. 348-5. $\bar{U} r j \bar{a}$, Bmḷ. Pur. p. 62, 13. Eenige der namen van de 7 zoons zijn verbasterd, doch, behalve Patra (elders Anaya, Anagha, Pavana e.a.), te herkennen.

-7. Cukra in overeenstemming met Viṣnu Pur. 1, 10, 14; vgl. ad Bmọ. Pur. p. 62, 14. Ndatan is onmisbaar.

Het meisje heet elders Punḍarīkā, Bmḍ. Pur. p. 62, 14 en Skt. teksten, b.v. Vā. Pur. 28, 34. Het oudste kind heet hier dus reeds ,,de achtste"!

-10. Sw $w h \bar{a}$, niet in het Bmḍ. Pur., waar Agni overgeslagen wordt (p. 62, 21). Zie echter Vā. Pur. 29, 1 sqq.; Skt. Bmọ. Pur. 1, 12, 1 sqq.: tasmāt (sc. Agneh) Svāhā, vyajāyata | Pāvakam Pavamānaṃ ca, Çucir agniç ca yah smṛtah | nirmathyah Pavamānas tu, vaidyutah Pāvakah smṛtah | Çucih sauras tu vijñeyah Svāhāputrās tu te trayah |. - Swāhāa, de bekende offerroep. Hawyazuāhana, Skt. Bmḍ. Pur. 1, 12, 4; Vã. Pur. 29, 4 Pavamānātmajaç caiva Kavyavāhana ucyate | Pāvakị̣ (Pāvakāt Vā.) Saharakṣas tu Havyavāhah Çuceh sutạ̣ | devānāṃ Havyavāho 'gniḥ, piț̣̂nām Kavyavāhanah | Saharakṣo 'surānām tu. - Saharakṣa > (sañ) Harakṣya. Onze tekst neemt Hawyawāhana als zoon van Pawamāna, doch ook als vuur der goden. Een der beide H.'s zal echter uit Kawyawāhana zijn ontstaan, doch welke, is on- 
zeker. Uit ${ }^{\circ}$ anak Kawyazuăhana, eerst met de $k$ één maal geschreven, later met $-k h$ - kan de foutieve lezing zijn ontstaan. Vgl. nog Taitt. Sạ̣h. 2, 5, 8, 6 trayo vā agnayo havyavāhano devānāṃ kavyavāhanaḥ pitṛnāṃ saharakṣā asurānām. Vgl. ook A. A. Macdonell, Vedic. Myth. (Grundriss), p. 97. - In het Skt. Bmḍ.- en Vāyu Pur. volgt thans het Agnivamçavarṇanam, een beschrijving van het geslacht van Agni. Andere Skt. teksten zijn hier echter belangrijk korter; bijzonderheden in mijn aant. op Bmḍ. Pur. p. 62, 21.

-20. Swadhā. Ook in het Bmọ. Pur. volgt nu de vermelding van haar kroost bij de Pitaras, echter zonder dat zij genoemd wordt. Rtu wordt daar niet vermeld; de kinderen worden daar en in de Skt. teksten anders genoemd (Bmḍ. Pur. p. 62, 23; zie ook de aant.).

-23. mastrī. Deze plaats stemt ten deele overeen met Skt. Bmḍ. Pur. 2, 2, 5; Brahma Pur. 3, 5; Vāyu Pur. 65, 128; Viṣnu Pur. 1, 15, 89 e.a.; zie Kirfel, P. P. p. 156, 6. Dakṣa, de Prajāpati werd n.l. later herboren als zoon van de Pracetas (Bmọ. Pur. p. 62, 13). Men zie over deze verdubbeling van de figuur van Dakșa, Wilson, Vishṇu Pur. II, p. 9, noot. Deze „,tweede” Dakṣa kreeg van Brahmā het bevel nakroost te verwekken en nam daartoe tenslotte een echtgenoote (b.v. Viṣnu Pur. 1, 15, 85 sqq.; Wilson-Hall, II, p. 12), geciteerd volgens Kirfel, t.a.p.: Asiknīm āvahat patnīṇ Vỉraṇasya prajāpateh | sutām sutapasā yuktām mahatīṇ lokadhāriṇīm. Het aantal zoons dat hij verwekt loopt in het Viṣnu Pur. e.a. in de duizenden; vgl. Kirfel, P. P., p. 156, 7 enz. Daarna verwekte hij dochters, die hij aan verschillende echtgenooten gaf, 10 aan Dharma enz.

Asiktiki, d.w.z. Asiknī der Skt. teksten; zie de Inl., p. 357.

De namen van de dochters luiden Vā. Pur. 66, 1; Skt. Bmḍ. Pur. 2, 3, 1; Viṣnu Pur. 1, 15, 105 e.a.: Arundhatī, Vasu, Yāmī, Lambā, Bhānu, Marutvatī, Sạ̣kalpā, Muhūrtā, Sādhyā, Viçvā (enkele geringe var.). Voor Yāmī staat dus Jāmili, een mij verder niet bekende vorm; voor dezen naam heeft echter het Çiva Pur. (Dharmasaṃ.), 54, 16 Jāmi, het Skt. Bmụ. Pur. Jāmā. Ook de volgorde wijkt af.

-28. saì Jāmili, enz. Men merke op, dat het hier volgende in het OudJav. Bmọ. Pur. ontbreekt. Nawawiti staat voor Nāgavīthī, de benaming van een sterregroep op den Uttaramārga (Kirfel, Kosmogr. p. 140). Men vgl. Skt. Bmọ. Pur. 2, 3, 33; Vā. Pur. 66, 34 ; Brahma Pur. 3, 32 e.a.

Wintai zenzenr (vgl. Bmḍ. Pur. 148, 23), de Melkweg.

-30. Marutzuān; in Skt. teksten, b.v. Viṣnu Pur. 1, 15, 109 wordt ge- 
leerd: pṛthivivișayạ̣ sarvam Arundhatyām vyajāyata, ,the divisions of the earth were born of A." (Wilson). De Marutvantah zijn zoons van Marutvatī, b.v. Viṣnu Pur. 1, 15, 107 ; Bmụ. Pur. 2, 3, 32 e.a.

Wiçzữ is elders de moeder der Viçvedeva's (-devatā's), vgl. b.v. Brahma Pur. 3, 30; Viṣnu Pur. 1, 15, 106. Men vgl. ook een uitvoeriger versie, b.v. Vã. Pur. 66, 31; (vgl. Bmọ. Pur. 2, 3, 30) Viçvedevās tu Viçvāyāṃ jajñire daça (geen constant aantal) viçrutāh | Kratur Dakṣaḷ Çravaḷ Satyạ̣ Kālạ̣ Kāmo Dhunis tathā | Kuruvān Prabhavāṇç caiva Rocamānaç ca te daça. - Onze tekst geeft 8 namen, een meer voorkomend aantal (vgl. Wilson-Hall, III, p. 179), behalve Dakșa echter verschillende namen). De namen van onzen tekst hebben vrij verregaande overeenkomst met die van 't Vã. Pur.; voor Dhuni heeft het Skt. Bmḍ. Pur. 2, 3, 30 zelfs Muni. Toch worden ze ook hier „daça-Wiçwa” genoemd; er zullen dus 2 namen uitgevallen zijn. Kratu is gelezen, daar -rě- zeer vaak i.p.v. ra staat in de hss.; vgl. b.v. Bmọ. Pur. p. 56, 9; 57, 16; 62, 9!

p. 349-3. Wasu; de Vasu's, een klasse van 8 godheden, personificaties van natuurverschijnselen, gevolg van Indra, zijn de kinderen van Vasu. Men vergelijke Bmọ. Pur. 2, 3, 20; Vișnu Pur. 1, 15, 111 (WilsonHall, II, p. 23). In onzen tekst is Anala (vuur) voor Anila (wind) uitgevallen. Voorts Prabhāta voor Prabhāsa (dageraad), een merkwaardiger wijze ook elders (in Vijñāneçvara's Mitākṣarā, 142, 1, een in Z.-Indië in de XIe E. ontstaan werk) voorkomende fout; zie ook Bmḍ. Pur. 2, 3, 21. - De hier volgende uitweiding over de kinderen van de Vasu's komt ook elders in dit verband voor.

-6. Dhara (sic) heeft elders 5 kinderen (Viṣnu Pur. 1, 15, 113 vlg., e.a., Kirfel's 1e groep), in 't Skt. Bmḍ. drie. Vgl. ald. 2, 3, 22 Dharasya putro Draviṇo Hutahavyo Rajas tathā. Het Vāyu Pur. althans de Bibl. Ind.-ed. $(2,5,21)$ luidt anders. - Kāla is Dhruva's zoon (Skt. Bmọ. Pur., t.a.p., e.a.). Soma heeft hier 4, elders (Skt Bmḍ. Pur. 2, 3, 23; Vā. Pur. 66, 22) 5 kinderen: Varcas, Budha, Dhara of Dhāra, Urmī of Ürmi, Kalila of Kalilas. Men zie de verknoeiïng. De le gr. v. Kirfel noemt slechts één naam. - De kinderen van Āpah zijn meer in overeenstemming met Kirfel's 1e gr.: Vaitanḍya, Çrama, Çānta of Çrānta, Muni of Dhvani (Muni, meest gelijkend op onzen tekst, b.v. Brahma Pur. 3, 37). Eén naam is hier uitgevallen; Vā. Pur. en Skt. Bmọ. Pur. wijken af.

-10. Kumāra wel, mèt andere Agni-zonen, Priyabrata niet in de verwante Skt. teksten. - De vrouw van Anila is daar Çivā (Bmḍ. Pur. 2, 3, 25: Anilasya Çivā bhāryā); kinderen Manojava, slechts Agni 
Pur. 18, 38 en Çiva Pur. (Dharmas.) 54, 24 Purojava $^{1}$ ) en Avijñātagati (Bmọ. Avijñāna ${ }^{\circ}$ ). — Dala, elders Devala. Viçvakarman ook elders. - De volgorde als de Bmḍ.-Vā.-groep.

-14. Sādhyā heeft tot kinderen de 12 Sādhya's (zie mijn Bmọ. Pur., p. 253), in de Bmḍ.-Vā.-groep opgesomd: de met de hier genoemde overeenkomende zes zijn: Citti, Haya, Haṃsa, Nārāyaṇa, Vibhu, Prabhava. Vijf der overige vormen één regel, die mogelijk in het origineel uitgevallen is; Naya (bij Haya) is wsl. uitgevallen.

-16. Marutzuati : is de moeder der Marutvant's (Bmọ. Pur 2, 3, 32 e.a.), die niet bij name genoemd worden: het Vā. Pur. leest (Kirfel. P. P. 176, 34) Marutah. Vgl. Hopkins, Epic Myth. pp. 169 vlg.

-17. Muhūrtã is de moeder der Muhūrta's, personificaties van tijdsduur. De tekst is hier onvolledig, de Muhürta's en de naam van Bhānu, de moeder der Bhānu's, zonnegodheden, zijn uitgevallen. Ghoṣa, bij Jahn, Saurap., p. 72, plur., elders, b.v. Viṣnu Pur. 1, 15, 108; Brahma Pur. 2, 3, 32, sing.

-21. nakșatra: vgl. de Inleiding, p. 361. Literatuur over de nakșatra's bij Kirfel, Die Kosmographie der Inder, p. 34; in den Archipel, vgl. D. van Hinloopen Labberton, Geillustreerd Handboek van Insulinde, Amsterdam 1910, pp. 40 vlgg., geciteerd bij Alfred Maass, Sternkunde und Sterndeuterei im malaiischen Archipel, T. B. G., 64 (1924), pp. 163 vlgg., waar men ook verdere bijzonderheden vindt ${ }^{2}$ ). Een overzicht van de nakșatra's met aantal hunner sterren en gedaante (zie de Inleiding) bij Kirfel, t.a.p., p. 138 vlgg.

-22. Açwinī, bij Kirfel, Kosm., p. 139, no. 27 ; daarna 28, dan 1 (Kṛttikāh), enz.; no. 4 heet Ārdrā (vgl. Bmc̣. Pur., p. 174, 20; 21), no. 5 Punarvasu (veelal dualis), no. 7 Açleșāh (de verandering ç $>\mathrm{k}$ is merkwaardig), no. 14 Viçākhā in een paar teksten (Garuḍaen Matsya Purāna), meestal in den dualis: Viçākhe, no. 15 Anurādhā (bh en $\mathrm{n}$ worden vaker verward), no. 16 Jyeșthā; no. 19 en 20, Uttarāṣāụhā en Abhijit, ontbreken (Abhijit is echter in de groepeering van $3 \times 3 \times 3-$ zie de Inleiding - niet opgenomen), evenzoo 22 en 23, Çravișțāh of Dhaniṣthā en Çatabhiṣaj, 24 heet Pūrvabhādrapadā (zie b.v. Wilson-Hall, Vishṇu-Pur. II, p. 268) of Pürvaproșthapade, no. 25 en 26 zijn van plaats verwisseld (weer: -padā).

-28. lima: volgens anderen: 1, elders ook 5 (vgl. Kirfel, Kosm. p. 138,

1) Na Purojawa heeft hs. $\mathrm{H}$ : saka ri strī nira san Açiwa, een toevoeging van een afschrijver; na den volgenden naam: anak ira waneh, eveneens.

2) Vergelijk vooral Pigeaud, T. B. G. 65, p. 282 vlgg.; zie Inleiding. 
en n. 4). Hier ratha, bij Kirfel çakața; in cle nakșatra-lijst bij van Hinloopen Labberton (zie T. B. G. 64, 164) en ook elders (Maass, T. B. G. 64 , tgr. p. 168) is sprake van een sterrebeeld padati suwun, ,leege wagen", in Friederich's opgave (zie Maass, t.a.p., no. 10) van padati çūnya ,id.”, volgens Maass is dit de Kleine Beer; Rohiṇi is (Kirfel, o.c., p. 36) $\alpha, \vartheta, \gamma, \delta, \varepsilon$ Tauri.

-29. paras-paras, in de Skt. teksten heeft dit sterrebeeld den vorm van een kșura, scheermes.

p. 350-1. wuk damaluin: de tekst springt over van no. 3 op no. 6; in de Skt. teksten gelijkt Puṣya op een pijl (çara, bāṇa). Op eenige astrologische kalenders (Maass, o.c., p. 166; tgr. p. 168, no. 15) komt Sidamalun voor, bij Friederich: Celen, wild zwijn; volgens Maass is Venus bedoeld; vgl. ook Maass, T. B. G. 64, p. 441; bij Kirfel, o.c., p. 36 is Puṣya of Tișya $\vartheta, \delta, \gamma$ Cancri. Over wuk damalun (Dam.) vgl. K. B. W. II, 520; Pigeaud, T. P. Bladwijzer en boven p. 387.

-2. liman, hier zonder naam, of bij het volgende te nemen?; no. 19 Uttarāṣậ̣hā heeft den vorm van een olifant. Gaja (gadjah) komt bij Friederich en elders voor (Maass, o.c., tgr. p. 168, no. 2; vlg. p. 164), bij Maass:= Stier en Plejaden; Uttarāsāạhā is $\sigma, \zeta$ Sagittarii. Vgl. beneden bij Jyeșthā.

ii těnah; Ardrā gelijkt in de Sanskrit teksten (no. 4 bij Kirfel, o.c., p. 138) op een edelsteen.

-3. akșara; Bharaṇi (no. 28) gelijkt in de Sanskrit teksten op een moederschoot (yoni); Açvinī (no. 27) op een paardekop (turagamukha, açva); het Paard (kuda, bij Friederich, elders djaran, Maass, tgr. p. 168, no. 11; p. 164, no. 3) komt in den Archipel voor; Maass identificeert het niet; Açvinī (zóó Matsya Pur., elders Açvayujau) is $\beta, \gamma$ Arietis. Steekt in de lezing van hs. $\mathrm{B}$ (vgl. F H) soms caturanga, vierdeelig leger, een soort schaakspel?

-5. parahu; Punarvasu (no. 5) gelijkt in de Skt. teksten op een grha (huis), hier op een soort schip (of een sirih-presenteerbakje, lañcan ?). Bij Maass, tgr. p. 168, no. 28 is sprake van prawu pĕgat, Banawah pasah, gebroken schip (= Argo), vgl. p. 164, no. 13, alsook van een jon sarat, volgeladen schip, op één astrologische kalender prahu zonder meer geheeten (= de Groote Beer). Punarvasu wordt geidentificeerd met $\beta, \alpha$ Geminorum. Het aantal sterren is in de Sanskrit teksten 2 of 4 .

-7. Maghā (zoo Matsya Pur.; elders plur.), no. 8 heeft in de Skt. bronnen 5 of 6 sterren en den vorm van een çālā (huis) of van een ākāra; het wordt geïlentificeerd met $a, \eta, \gamma, \zeta, \mu, \varepsilon$ Leonis. 
Bij Maass, p. 164, no. 4 is sprake van gubug pencen, het scheeve huisje (= het Zuiderkruis), elders lumbun, rijstschuur. Hier is dus wel niets meer te zien dan een toevallige gedeeltelijke overeenstemming van een door Hindoes en Archipel-bewoners ergens aan den hemel geziene gedaante van een sterregroep. De gedaante die onze tekst noemt ken ik niet van elders.

-8. Hasta (hand) is de vorm van het gelijknamige maanhuis no. 11; met 5 sterren in de Skt. teksten.

-10. salah ukur; Viçākhā (no. 14; 2 of 4 sterren in de Skt. bronnen) gelijkt op een dhiṣnyatorana, ,Tor einer Weltgegend?” (Kirfel, p. 139) of op een torana, ,boog, poort, eerepoort” zonder meer (dhișnya kan o.a. zijn: wat slechts met den geest kan worden waargenomen; woonplaats, huis, verblijfplaats; sterrebeeld). Bij Friederich vinden we salah ukur (zie Maass, tgr. p. 168, no. 122: „Unzufriedenheit und fortdauernder Streit mit Menschen"?), ook bij Van Hinloopen Labberton, bij Maass, t.a.p. en p. 164, 5 ,verkehrt ausgemessen”. Onze tekst geeft met wanun ${ }^{2} a n$ salah-ukur een volledigere en m.i. de oorspronkelijke benaming. Of dezelfde sterren bedoeld zijn en er tusschen torana en wanun²an verband bestaat, kan ik niet uitmaken, Maass geeft geen identificatie; Viçākhe zijn $\iota, \gamma, \beta, \alpha$ Librae.

-11. Citrā (no. 12) en Svāti (no. 13) gelijken op een parel of lamp en op een pravāla, koraal of parel.

-12. Uttaraphalguni (no. 10) heeft in de Skt. teksten 2 of 5 sterren en gelijkt daar op een rustbed, paryanka; de volgende (no. 9) heeft daar 2 sterren en gelijkt op een çayana, paryanka, eveneens dus op een rustbed (wel te zamen met de vorige). [Zie addenda].

-13. hĕ $u$ uk, zie K. B. W. I, 160.

-15. Amurādhā (no. 15) gelijkt op 'n offergave (bali) of op een boog, poort (torana; vgl. boven en Kirfel, p. 139) en heeft 3 of 4 sterren in de Skt. teksten.

-17. Jyesthā, (no. 16, met 1 of 3 sterren) heeft in de Skt. bronnen de gedaante van een ring (satkundala). Boven hebben we reeds een liman ontmoet. Jyeșthā is te identificeeren met $\alpha, \sigma, \tau$ Scorpionis.

-18. saíkal tikĕl, gebroken steel van 'n bijl, ook in de opgave uit Klungklung (Maass, o.c., p. 164, no. 25), en in eenige astrologische kalenders (Maass, o.c., tgr. p. 168, no. 21) ; volgens Maass te identificeeren met ,, , x, R, v scorpii”. Mūla, no. 17 in de Skt. opgaven, heeft daar 7, 9 of 11 sterren en gelijkt op een stap van 'n woedenden leeuw (kruddhakeçarivikrama) of 'n wijnpalm (tāla); dit nakșatra

D1. 92. 
is $\lambda, v, \varkappa, \iota, \vartheta, \eta, \zeta, \mu, \varepsilon$ Scorpionis. Hier dus een zekere overeenstemming in sterren!

-19. Pūrvāṣădhā gelijkt in de Skt. opgaven op een çayã (bed) en heeft er 2 of 4 sterren.

-20. Çatabhisa, Çatabhișaj van de Skt. teksten, heeft daar 1 of 100 sterren en den vorm van een vrtta, kring. De beide volgende hebben aldaar ieder 2 sterren en gelijken resp. op een tweelingenpaar of een (rust)bed (dit wel samen).

-22. pujuh ataruin; vgl. bij Van Hinl. Labb. (Maass, o.c., p. 164, no. 27) pujuh tarun, ,die Kampfwachtel”, elders eveneens (zie Maass, o.c., p. 168 , no. 34) ; ze worden daar gelijk gesteld met , $\mu$ und $\zeta$ scorpii”. Vgl. Wilkinson, Mal.-Engl. Dict., II, 4 puyoh berlaga. Revatī, met 1 of 32 sterren is in de Skt. bronnen no. 26 en heeft daar den vorm van een tamboerijn (muraja); ze is $\zeta$ Piscium.

-24. Cravana heeft in de Skt. teksten denzelfden vorm of ook die van drie voetstappen (trivikrama); aldaar no. 21 met 3 sterren. - Als laatste wordt hier nog de boven overgeslagen Dhanisțha vermeld; in de Skt. bronnen is haar vorm een mrdanga, 'n soort trommel; ze heeft 4 of 5 sterren. - De lijst vertoont dus vele verschillen zoowel met de opgaven en beschrijvingen der nakșatra's in de Sanskrit geschriften, als met wat we bij Maass, t.a.p. vinden. Er bestaat echter, zooals reeds in de Inleiding opgemerkt, nog meer variatie.

-27. Suranadī; over wintan wuwur zie boven. Suranadī, Devanadī e.a. zijn namen voor den Ganges, die van den hemel neerkomt. Vgl. OudJav. Bmọ. Pur. p. 147, 28 vlgg., -voor wintan wuwur p. 148, 23.

Voordat de tekst op de dochters van Dakṣa terugkomt, deelt hij ons in een uitvoerig intermezzo allerlei andere bijzonderheden mee.

p.351-4. kena, een dergelijke vraag stelt Yudhișthira aan Bhīṣma, Mbh. 13, 111, 2 (5398) : kena vṛttena rājendra vartamānā narā bhuvi | prāpnuvanty uttamạ̣ svargạ̣ kathạ̣ ca narakạ̣ nụpa.

-10. kāyikah̆ (zie ook beneden), vgl. Mānavadharmaçāstra, 12, 3 çubhāçubhaphalaṇ karma manovāgdehasambhavam | karmajā gatayo ṇ̛̣nām uttamādhamamadhyamāh.

-11. svargasopāna, vgl. Hariv. 14521.

-15. sāmagrī ; Skt. samagra, volledig, compleet, geheel; neutr. alles; hiervan: sāmagrī, totaliteit, volledigheid van alles wat ergens aanwezig dient te zijn; alsook sāmagrya, idem; K. B. W. III, 351 en Juynboll, Wdl. 592 te corrigeeren.

-22. çarīrajaih, deze çloka stemt volkomen overeen met 't Mānavadhar- 
maçāstra, 12, 9. Uitgebreid Yājñ. 3, 134-136; met eenigszins andere woorden Yājñ. 3, 131. Vgl. ook Manu, 12, 5-8. De omschrịving wordt eenigszins anders gegeven, bij de mānasa-zonden b.v. (Manu, 12, 5) : paradravyeșv abhidhyānam manasānișthacintanam | vitathābhiniveçaç ca trividhạ karma mānasam. - Deze trits komt vaak voor; in 't epos b.v. Mbh. 18, 303 kāyikam vācikam caiva manasā samupārjitam; in het Mahānirv. T., 3, 75: men kan den hoogsten Heer op deze 3 wijzen vereeren; enz. Voorts Viṣnu Pur. 3, 12, 45 e.a. mleccha, bij Manu, vgl. hier in 't citaat, antyajātitā. Mleccha's zijn „,barbaren”; in de Sanskrit literatuur worden ze herhaaldelijk genoemd met ketters, verachte volksstammen, uitgeworpen çūdra's. Zie ook Kern, V. G. 8, 93; K. B. W. IV, 585. De naam is, als caṇdāla, nog op Bali bekend; vgl. Korn, Adatrecht van Bali², p. 168.

p. 352-5. eman, vgl. p. 391, 5; bet. verwant met die van Soend. heman?

-10. dharmaçilam; blindheid als gevolg van zonden in een vorige existentie, b.v. ook Manu 11, 52 (in eenige hss.) : dīpahartā bhaved andhah, ook Viṣnu-smrti, 45, 20 wegens stelen van 'n lamp; 45, 19 wegens dooden van 'n koe (vgl. nog 45, 32); Gar. Pur. Sār. 5, 8, wie een boek steelt.

-11. Mahāraurava is een vaak genoemde hel (schildering Mārk. Pur. 12, 3-9; van gloeiend koper; geboeid wordt de booswicht daarin een prooi van kraaien, wolven, muskieten, gieren, enz., $1000 \times 10000$ jaar; zie ook Brahma Pur. 215, 99: een vlammenzee), waar volgens Bhāg. Pur. 5, 26, 12 e.a. iemand gestraft wordt, die slechts op eigen behoud bedacht is en zich niet om anderen bekommert, volgens Agni Pur. 203, 8, iemand, die zich aan brandschatting bezondigt, evenzoo Br. Pur. 215, 99, waar ook moordenaars van vrouwen, kinderen en grijsaards.

-21. hana ujar: stomheid, bij Manu 11, 51 e.a.: maukyam vāgapahãrakah, wsl. iemand die zonder vergunning den Veda leert, plagiaatpleger van den Veda, bij Viṣnu 45, 15 ook iemand die een god of brahmaan beschimpt; vgl. 45, 33; Gar. Pur. Sār. 5, 8 een valsche getuige.

-25. rasendriya, vgl. het glossarium. Zie de aant. bij p. 375, 21. In tegenstelling met p. 399 (d1. 90) niet corrupt te achten.

-28. çravanīyam; dooven, bij Manu $(11,53)$ en Viṣnu $(45,33)$ in het algemeen genoemd; Gar. Pur. Sār. 5, 9 wegens hooren naar onwaarheid.

p. 353-1. hitāwasāna; men kan dit opvatten als Skt. hita + avasāna, einde; doch het is m.i. minstens even waarschijnlijk aan hita $+v \bar{a} s a n \bar{a}$ te 
denken. „Ein jeder Vorgang prägt eine entsprechende Spur ein in den Boden des Denkorgans, und diese Spur verharrt da als ein Keim im Ackergrund oder als eine Disposition für die künftige Reproduktion dieses Vorganges... Diese Dispositionen... bilden bei ihrer unendlichen Menge ein sehr wesentliches Attribut des Denkorgans". Dit denkorgaan blijft echter ,der nährende Boden, das verknüpfende, einheitgebende Band, das Substrat, zu welchem sämtliche Dispositionen nur Attribute sind". Zie Paul Markus, Yoga-Philosophie, pp. 36 vlgg.; vgl. Garbe, Sāṃkhya Phil.2, pp. 331 vlgg.; Tuxen, Yoga, pp. 114 vlgg. Deze door den geest ontvangen en daarin als dispositie blijvende voorstellingen heeten $v \bar{a} s a n \bar{a}$.

-8. yo dharmam; gebrekkigheid, lamheid, bij Viṣnu 45, 14 (açvāpahārakah panguh) en Manu, 11, 51 straf voor paardedieven; Gar. Pur. Sār. 5, 9 voor hem die een brahmaan of koe met den voet stoot.

-18. dauçcarmyam, vgl. Manu 11, 49: dauçcarmyam gurutalpagah (sc. prāpnoti). Vgl. Viṣnu 45, 6 (g-o duçcarmā); Yàjiñ. 3, 209, ook Agni Pur. 370, 32 (duçcarmā g-ah) ; Gar. Pur. Sār. 5, 4 (evenzoo). Het schenden van het bed zijns leeraars is een der 5 groote zonden (brahmanenmoord, surā-drinken, diefstal van het goud van een brahmaan, echtbreuk met de vrouw van den guru en connectie met schuldigen daaraan), volgens Manu 11, 54 (vgl. 9, 235); Viṣnu 35, 1 e.a. (zie Bühler, S. B. E. 25, 441). Bij de opsomming der hellestraffen en derg. worden schuldigen daaraan dan ook steeds genoemd (b.v. Viṣnu Pur. 2, 6, 10; Wilson-Hall, II, 216; Bmḍ. Pur. 4, 2, 155; Vã. Pur. 101, 153 e.a.); ook wereldlijke straffen zijn er op gesteld (Manu 9, 237: gurutalpe bhagah kāryah, een vulva worde hem op 't voorhoofd ingebrand; vgl. b.v. Baudhāyanadh. ç. 1, 18, 18; Viṣnu 5, 7); in een volgende existentie wordt een dergelijke zondaar b.v. een zwijn voor 5 jaren, daarna 'n wolf voor 10 jaar, 'n kat voor 5 jaren enz. enz. (Mbh. 13, 111, $76=5474$ vlgg.), of 100 malen gras, kruipplanten, rauw-vleesch-etende dieren enz. (Manu 12,58 ); ook boetedoening (b.v. op 'n verhit ijzeren bed liggen, 'n rood-gloeiend vrouwenbeeld omarmen, ,,door den dood wordt hij dar rein”, e.a., Manu, 11, 103 vlgg., vgl. Bühler, S. B. E. 25, 451 vlg.; vgl. b.v. ook Mbh. 12, 36, 20). - Vaak dus duçcarma, wsl. een ziekte, waarbij de huid verhardt (bijz. Abegg, Pretakalpa, p. 83), elders (Padma Pur. 4, 48, 55) mūtrakṛcchra, (aan) strangurie (lijdend). - Men lette hier op het toegevoegde anak nin guru.

-23. agamyāganana, volgens Manu 11, 58; 170 e.a. is de vleeschelijke vereeniging met vrouwen, behoorende tot de agamyā's (zooals zusters 
van dezelfde moeder, vrouwen van zoons of van vrienden, ongehuwde meisjes, vrouwen van de laagste klassen) ongeoorloofd; volgens Manu, t.a.p., e.a. is overtreding gelijk te stellen met gurutalpa; zoo b.v. ook volgens het Garuḍa Pur. (a. 105) in een zonden-opsomming; veelal wordt dat misdrijf echter afzonderlijk opgegeven. Door dergelijke verbintenissen ontstaat kastenmenging (Mbh. 13, 2580). Als verzoening wordt b.v. vermeld: gedurende zes maanden een nat kleed dragen en op 'n bed van asch liggen (Mbh. 12, $1275=35,35$ ). Vgl. ook Kürma Pur., Utt. bh. 33, begin, waar allerlei gevallen onderscheiden worden; v. Negelein, Tr. Jagaddeva, p. 118. Vreeselijke hellestraffen staan er op: Br. Pur. 22, 12 vlg., zie ook Viṣnu Pur. 2, 6, 13, Wilson-Hall, II, p. 216; Br. Pur. 214.

Wat de ziekten en kwalen in een volgende existentie betreft: het Padma Pur. 4, 48, 55 vlgg. onderscheidt gevallen: na verkeer met eigen dochter: raktakușthah prajāyate, na verkeer met zuster: pitakușthah, met broers-vrouw : gulmakușthah, bij svāmigamyādigamana : dadrumaṇdala, bij viçvastabhāryāgamana: gajacarma, voorts in andere gevallen: dakṣinānge vraṇī, vāmānge vraṇavān, kațau kușthah. Zooals men ziet, veelal kuștha, waaronder ,gemeinsam eine sehr gefährliche, die schwersten Entstellungen hervorrufende Hautkrankheit, der sog. schwarze Aussatz" (Jolly, Med. § 68) verstaan wordt: echter ook ruimer ,huidziekten”. In Gar. Pur. Sār. 5, 4 wordt bepaald: agamyāgamanāt șanḍho, door omgang met een vrouw met wie uitoefening van den bijslaap verboden is wordt men impotent, 'n hermaphrodiet.

-25. kaçaktin winryanya, vlg. $\mathrm{y}$ is te vergelijken met Bmọ. Pur. p. 55, 27 (zie de aant., p. 236). Wat in den tekst te lezen?

-26. pantikrama wordt door Juynboll, Wdl., 338; 326 met „,volgorde' vertaald. Wirātap. p. 91: de Pānḍawa's, gebaad en mooi gekleed, komen bij den koning der Matsya's binnen, masila mapariktikrama, malunguh atata ri palunguhan in ratu sāmanta, correspondeerend met adhy. 65 (Utg.), begin. Voorts ibid. p. 13: haywâwěrö denin kawallabhan, tan ginakĕnâsin sakahyun san prabhu, tan songwanungwana lawan kelik nira, atutâtuturen pantikrama, etc. Vgl. Mbh. 4, 4, 23 (Uttg.) nāsyāniștāni seveta nāhitaị̣ saha sạ̣viçet svasthānān na vikampeta sa rājavasatị vaset || dakșiṇaṃ vātha vāmạ̣ vā pārçvam āsīta paṇ̣itah, etc.

Skt. pankti is rij, groep, vereeniging, gezelschap, ,company”. „Iemand, die de beteekenis van den Veda kent..., iemand die 1000 (koeien) geeft, een honderd-jarige zijn brāhmaṇāh panktipāvanāh, 
brahmanen die een gezelschap reinigen, wijden". Van belang voor onze plaats is b.v. Mbh. 13, 90, 5 vlgg. (= 4274 vlgg.), waar een lange opsomming gegeven wordt van brahmanen, die een of andere zonde begaan hebben en daardoor panktidūsāh zijn geworden, d.w.z. personen, die een gezelschap verontreinigen; dientengevolge moeten ze bij een çrāddha (doodengave, -maaltijd) worden geweerd, evenals honden (ibid. $22=4290$ ). Onder deze personen zijn o.a. embryodooders, teringlijders, giftmengers, dieven, enz., maar ook echtbrekers en zij, die het bed van hun guru schenden. Men verg. b.v. ook Bmḍ. Pur. 2, 15, 40; 41; 55 : pankktidūṣakāḥ. Zij zijn apāñkteyāh, of zooals Manu, 3, 169; 176 e.a.; 11, 200, het zegt: apāniktyāḥ; Manu, 3, 151 vlg., verklaart in 'n dergelijke opsomming o.a. lieden die durbala zijn hiertoe (durbala: duçcarmā, Kull.), als ook zij die met 'n outcast door huwelijk of anderszins verbonden zijn, en ook een çvitrin ( : çvetakușthayuktah, lijjend aan witte melaatschheid, Kull., 161), dus ook de categorieën van onze passage (zie Vā. Pur. 78, 72; Bmạ. Pur. 3, 15, 53 vlgg.). In Gar. Pur. Sār. 5, 7 is sprake van een panktibhedaka; de Eng. vert. van Wood en Subrahmanyam (geciteerd bij Abegg, Pretakalpa, p. 84) verklaart: ,who breaks the mealrow (this refers to the custom among Brahmins of sitting in a row at meals, and rising together. Whoever gives different food to one than to another is said to break the row also)". We hebben dus voor pankti de beteekenisovergang: rij > groep personen die in 'n rij aanzitten. Zoo begrijpen we de vertaling van M. N. Dutt van bovengenoemde Mbh.-plaatsen: ,who pollute the line”, ,that should be excluded from the line". Dit laatste gaat dan over tot ,who is unworthy to sit in the company" (Bühler, S. B. E. 25, 107), of ,nicht würdig einer geachteten Gesellschaft anzugehören, mit andern geachteten Personen an Etwas Theil zu nehmen" (P. W. I, 299); pañktidūṣa tot ,ein Schaden für die Gesellschaft” (P. W. IV, 354). Voor panktikrama $>$ Jav. ook pantikrama, dat ik slechts uit Jav. teksten ken, komen we dus tot een beteekenis: ,de wijze van doen, van optreden, de bestaande gebruiken in een (in de rij aangezeten) gezelschap” $>$,in een achtenswaardig gezelschap, onder lieden van standing, gepast gedrag”. Zie echter ook Rangga Lawe, 1, 107.

-27. çlestan; reeds van der Tuuk, K. B. W. III, 255, vroeg zich af of hier niet aan Skt. çleșman, kleverige stof, slijm te denken is, wat goed in het verband zou passen. Misschien uit ${ }^{\circ}$ clișta? of een quasiSanskrit vorming?

-28. piçunah ; aldus bij Manu 11, 50; vgl. Viṣnu-Smı̣ti; 45, 7 (pūti- 
nāsah piçunah), Agni Pur. 370, 34 ( $\mathrm{p}^{\circ}$ pūtināsikah ; anders Padma P. 4, 48, 44: kāsaçvāsavān, hoestend en hijgend.

Pitinasyam is de naam van een neusziekte, de lijders hebben een stinkenden adem ( $p \bar{u} t i=$ bedorven, rot, stinkend) uit mond en neus : Jolly, Med. p. 116.

F. 354-2 pūtivaktrah, Manu, 11, 50 vervolgt: sūcakah pūtivaktratām; vgl. Vișnu 45, 8. Bij Yājñavalkya, 3, 211 (202) en elders, b.v. Agni Pur. 370, 34: pūtivaktras tu sūcakah. Een sūcakah is een aanbrenger, verrader, aanklager, delator. De tekst is wel zeer afgeweken van de lezing die ik vermoed, áls deze er gestaan heeft (ook de Jav. tekst geeft niet geheel en al sücaka weer). Galavedanāh noemt Var. Pur. 203, 16.

-5. pitrkopād. Over koorts, enz. Jolly, Med. pp. 70 vlgg. Verscheidene teksten noemen echter als zonde: twist te hebben met $z$ 'n vader (Mbh. 13, 90, 4277), haat tegen z'n vader (Br. Pur. 22, 14; Viṣnu Pur. 2, 6, 14), verlaten van den vader (Yājñ. 3, 237; Vịṇu 37, 6; Manu 11, 59; vgl. 8, 389); zie voorts plaatsen als Manu 8, 275; 3,$157 ; 159$. Ook de moeder wordt veelal genoemd.

unmatah, in dezen vorm afwijkend. Een overeenkomstige mededeeling heb ik bij Viṣnu niet aangetroffen, bij Manu 11, 51 is een varia lectio: vātāngah pāradārikah (Kull.), vgl. Bühler, S. B. E. 25, 440, n., Bühler vat op: ,an adulterer (will have) swellings (in his limbs)". Moet men hier denken aan vātula, vātūla, $1^{0}$ winderig, $2^{0}$ unmatta, gek, waanzinnig? Onder vātavyādhi, ,windziekte”, worden rheumatische ziekten, nerveuze kwalen, verlammingen, krampen, verstaan: Jolly, Med. pp. 118 vlgg.; veroorzaakt door den wind in het lichaam. Volgens Manu 12, 60 worden deze overtreders herboren als brahmarākșasa's (: bhūtaviçeșah Kull.; vgl. b.v. Mbh. 9, 43, 21). Evenzoo elders, b.v. Yājñ. 3, 212 (zie echter 3, 136), bijna gelijk daaraan Agni Pur. 370, 35; Gar. Pur. Sār. 5, 37. Een eunuch wordt hij Mārk. 15, 37 vlg.; een wolf Brahma Pur. 217, 66.

-9. bhatțāra Manu, vgl. de Inleiding, p. 378.

-15. pāndutvam, ,unter dem Namen pāndu, pānduroga, pāndvāmaya, „krankhafte Blässe” werden verschiedene in Indien besonders häıfige krankhafte Veränderungen der Hautfarbe zusammengefasst, wie auch das vedische hariman vielleicht nicht ausschliesslich auf die „Gelbsucht" zu beziehen ist", Jolly, Med., p. 86, alwaar een uitvoerige beschrijving.

-19. agĕlěm amorakĕn ; 'n miçraka is een (koren)menger, d.w.z. iemand die slecht graan door het goede mengt. Manu 11, 50: ātirekyam. 
tu miçrakah, dus een andere kwaal (zie ben.), vgl. ook Viṣnu 45, 10: miçracoro 'tiriktāingah, vgl. Yājñ. 3, 211. In het Balineesch schrift worden $h$ en $t$, alsook $n$ en $k$ nog al eens verwisseld; zie Wulff, Wirātap., resp. p. 174 en p. 178.

-21. dhānyacauro 'ngahīnatvam, ,een graandief : mankement aan leden” leert Manu 11, 50; vgl. hierbij Viṣnu 45, 9; echter Agni Pur. 370, 34 dhānyạ̣ hṛtvā 'tiriktāngaḥ (vgl. ibid. 36: mukharo dhānyahārakạ̣).

-24. adaw'a, hier schijnt het citaat te zijn verloren gegaan. Hier boven zagen we, dat een miçraka in verscheidene teksten te groote ledematen zou krijgen; elders 'n graandief. Onze tekst wijkt hiervan af. Uitvoerige, gespecificeerde opgaven omtrent diefstal b.v. Manu, 12, 61 vlgg. (olie, 63) ; Vișnu, 44 (olie, 23) ; Padma Pur. 4, 48, 49 vlgg.; Agni Pur. 370, 34 ; Gar. Pur. Sār. 5, 11, met onderlinge verschillen.

-31. Mahāniraya; niraya beteekent ,hel”; Feer, L'enfer indien, I, Journ. asiatique, 1892, 187, constateert, dat de Boeddhistische teksten bij voorkeur niraya, de Brahmanistische naraka bezigen. Mahāniraya is de zevende, ijzeren, vlammende hel die de oudere Boeddhistische opvattingen over de hellewereld kennen (Kirfel, Kosmogr. d. Ind., pp. 199 vlg.). Intusschen is de benaming ook elders te vinden; vg1. Yãjñ. 3, 222, waarbij op te merken valt, dat in de drie teksten, die mèt Yājñ. hier ongeveer dezelfde opsomming van 21 hellen hebben, hoewel de volgorde en de vormen der namen onderling eenigszins varieeren, n.l. Manu, 4, 88 vlgg.; Viṣnu, 43, vlgg., Agni Pur. 370, 20 vlgg., op de overeenkomstige plaats van Mahāraurava, de in onzen tekst reeds vroeger genoemde hel; sprake is (zie ook: Kirfel, o.c., p. 152). Voorts Mahāniraya: Gar. Pur. Sār. 3, 62.

p. 355-1. ätizuāhika-çarīra is ook elders het lichaam, waarin de ziel terstond na den dood wordt weggevoerd. De Sāṃkhya-philosophie leert, dat de dertien organen, die niet als het grof-materieele lichaam vergankelijk zijn, de ziel op haar tocht door de existenties begeleiden; ze vormen met de vijf fijne elementen een innerlijk lichaam, linga, lingaçarìra, ,karakteriseerend lichaam (dit lichaam bepaalt n.1. het wezen en karakter van het individu)", sūkșmaçarīra, fijn lichaam, of ātivāhika-çarīra, ,het overvoerende lichaam”. Vgl. Garbe, Sāṃkhya-phil. ${ }^{2}$, pp. 327 vlgg. $\mathrm{Na}$ in dit lichaam overgevoerd te zijn, krijgt de gestorvene een bhogadeha, vergeldingslichaam volgens plaatsen als Agni Pur. 368, 13 pretadeham samutsrjya bhogadeham prapadyate | bhogadehāv ubhau proktāv açubhaçubhasaṃjñikau (waar overigens de voorstelling gegeven van àtivāhikaçarīra anders is dan 
zoo juist gezegd). Hier worden dus twee bhogadeha's onderscheiden, in het eene geniet men de vruchten van z'n goede daden, dit wordt ook elders, b.v. Gar. Pur. Sār. 9, 48, divyadeha, ,goddelijk lichaam” genoemd; dit is de engere beteekenis van bhogadeha. Op vele andere plaatsen wordt ook een yātanadeha, ,pijnigingslichaam” genoemd; uit vergelijking van b.v. Gar. Pur. Utt. Kh. 8, 38 vlg. met Gar. Pur. Sār. 2, 82 vlg. blijkt, dat dit een uit het karma van den gestorvene ontstaan lichaampje ter grootte van een duim is; het is vāyuh, khecarah (lucht, luchtachtig en door de lucht gaande); in dit lichaam lijden de zondaars na hun dood de pijnen van de hel. Het in onzen tekst hiervoor staande tucchita (de hss. hebben tucita), leeg, nietig, ken ik niet van elders. Van een oorsprong uit het karma van het vroegere lichaam spreekt b.v. ook Mārk. Pur. 10, 63. Overigens vindt men genoemde woorden niet overal geheel eender gebezigd; de kwestie is echter niet in 't kort uiteen te zetten. Enkele bijzonderheden: Abegg, Pretakalpa, pp. 38; 57; 113.

-14. Dharma $=$ Yama, de rechter der dooden; zoo vaak.

-16. pipilika, over wedergeboorte als dier b.v. Manu, 12, 62 vlgg.; Viṣnu, 44, 14 vlgg.

-20. tapa, yajña, kìrti. Het voorafgaande citaat heb ik (nog?) niet kunnen identificeeren. Offeren is een vereischte voor verlossing (Manu, 6, 36; e.a.), askese (b.v. Manu 6, 75; 85; vgl. 12, 84 vlgg.). Offers, askese, schenkingen, geloften noemt b.v. het Saura Pur., 1, 10; vgl. 20. Het Gar. Pur. Sār. 15, 92 vlgg. noemt tapas, yoga en dergelijke wegen tot de verlossing: tapoyogādayo mokṣamārgāh santi (92) ; vgl. ook 94 : yajñādayo hi saddharmāç cittaçodhanakārakāḥ.

Over de beteekenis van kìrti hoop ik elders te handelen. De Skt. teksten gebruiken andere termen, b.v. Manu 12, 31: dharmakriyā ( : dānādidharmānuṣthāna Kull.). Zie ook Vogel, B. K. I., 1906, 344.

-23. indriyanigraha, b.v. Manu, 12, 31.

-24. daçendriya, zie beneden; Goris, Bijdr., pp. 66 vlgg.; 118. agnihotra, vgl. Pet. Wdb., s.v. - Çizeāgni, zie ben. winch mať̌mahan; vgl. b.v. Saura Pur. a. 43, beg., a. 44 beg.: het stichten van 'n tempel bewerkt o.a. verlossing. Het sieren met bloemen van ringmuren, paviljoenen, torens, poorten brengt groote verdienste; vgl. 10, 21 (gave van land enz. aan armen).

-27. lěwoih, vgl. plaatsen als Yãjñ. 1, 199: beter dan Vedastudie kriyā (godsd. handelingen), beter dan dat het kennen van den adhyātma, hoogste geest; Manu, 12, 85. 
prawrtti, werkzaamheid, tgr. nizurtti, het afzien van (handelen); vaak tegenover elkaar gesteld. Vgl. Manu, 12, 85 vlgg.

p. 356-1. yajña lima, vgl. b.v. Āçvalāyana Gṛhyasūtra, 5, 3, 1, 2; zie Jolly, Recht und Sitte (Grundr.), § 57. Manu 3, 81: svādhyāyenārcayetarṣin homair devān yathāvidhi | piț̣̂n çrāddhaiç ca nụ̂n annair bhūtāni balikarmaṇā. Vgl. ook 4, 21; Baudh. 2, 111 vlgg.; Viṣnuu 59, 20 vlgg.; Yājñ. 1, 102 e.a. Straffen tegen overtreding (nalatigheid) : Brahma Pur. 215, 111; Bhāg. Pur. 5, a. 26; Manu 3, 70 vlgg.

-3. taila, tila, sesam-plant, -korrel; taila, sesam-olie, olie in het algemeen, ook wierook. Zie ook K. B. W. II, 691. Tekst in orde? Over het gebruik van sesam enz. - bij çräddha's - b.v. teksten als Manu, 3, 210; 234; 235; 255; 267; Vișnu Pur., III, p. 116 bij Wilson-Hall; echter ook b.v. Mahānirvāṇa T., 6, 160, „de Iștadevatā aanroepend,... offerend met een mengsel van ghee, sesamzaad, honig en bloemen"; vgl. Avalon, p. 307, n. 2.

Çizuāgni, vgl. Bmḍ. Pur. 121, 1; 4 (aant. p. 286) ; Wirāțap. p. 13; Kid. Harșa-Wijaya, 6, 88a; 92a; Babad Bla-Batuh, 2, 37 e.a.

-5. kapūjān, vgl. Manu 3, 70; 96 vlgg. e.a.

-6. Çizeaçräddha, over çrāddha's, b.v. Manu, passim (vooral 3, 122 vlgg.).

-9. bhütayajũa, vgl. b.v. Manu, 3, 70; 74; 80 e.a.; Viṣnu, 59, 27; e.a.

De nu volgende passage levert eenige moeilijkheden op. De woorden of namen laten zich niet met volkomen zekerheid verklaren. 'n Bhūtayajña is een offer voor de bhüta's, eigenlijk ieder schepsel, in 't algemeen, maar vaak gedacht als een soort geesten, spoken, kwade daemonen. Men vergelijke Vișnu Pur. bij Wilson-Hall, III, p. 118; Hopkins, Epic Myth. § 16: The Bhūtas ... are indistinct to the epic poets, who have not yet arranged the genealogy of spirits so as to make the Bhūts derive from Krodhā... They are not yet clearly ghosts. In modern times Bhìts are identified with Pretas, the concept including imps, ghosts, and goblins".

Men lette hierbij op 'n mededeeling als Çatap. Br. 11, 5, 6, 2 yad balim karoni sa bhītayajñah. Een balikarman is het brengen van 'n bali-offer, waaronder men verstaat iedere eeregave, die niet valt onder het eigenlijke offer, gebracht aan goden, goddelijke wezens, enz. Men zie b.v. de beschrijvingen bij Manu 3, 87-94; Viṣnu, 67, 4-22 (vgl. de aant. van Jolly, S. B. E., 7, pp. 211 vlg.). Met wat van den maaltijd overblijft worde 'n bali-offer gebracht (Viṣnu 67, 4); allerlei goden, daemonen en ,.personificaties" voor wie deze gaven bestemd zijn worden opgesomd. Aan dergelijke plaatsen denkende zou 
men ook hier kunnen verwachten een zoodanige opsomming te vinden. $\mathrm{Nu}$ komt Tuwuhaḍa ook elders voor: in een door Kern uitgegeven in een inscriptie voorkomend vervloekingsformulier (V. G. VI, 294; vgl. Brandes, Pararaton ${ }^{2}$, pp. 112 vlgg.) in een lange reeks namen van goden, personificaties, heilige plaatsen, enz.; Kern vertaalt (p. 296) met ,geest van Tuwuhaḍa” (kamun hyan T.) ; zekerheid, dat een berg bedoeld is, heeft hij niet (p. 307); Pigeaud (T. P., p. $254, n$.) acht het mogelijk, dat het 'n naam van 'n heilige plaats is, waarvan de bovenmenschelijke bewoners aangeroepen worden. $\mathrm{Pa}$ munggwan (dus -ng-) staat daar even eerder (san hyan P.). In dit formulier komen echter allerlei personificaties voor: de windstreken, elementen, zintuigen, tan-mātra's, zooals trouwens wel vaker. Het valt te betwijfelen, of b.v. bij het noemen van de tan-mātra's nog veel begrip van de eigenlijke beteekenis aanwezig geacht moet worden. Dergelijke opsommingen maken op mij den indruk vele namen te bevatten uit oudere geschriften en traditie, waarvan de juiste beteekenis is gaan vervagen. Het zou dus mogelijk zijn, dat ook Tuwuhạ̣a e.a. in het formulier oorspronkelijk in teksten thuis behoorden, waar ze, in 'n ander verband zeer wel zin gaven, zonder daarom de naam van 'n heilige plaats te zijn. Het meest voor de hand ligt het, aan een plaats in 'n tekst, die den indruk wekt uit het Sanskrit vertaald te zijn voor de vaststelling van de eigenlijke beteekenis van het woord of de woorden de voorkeur te geven, i.c. dus aan het Agastyaparwa. Sain hyai staan er hier niet bij. Kunḍa zou men misschien mogen vergelijken met Viṣnu 67, 6: de balioffergaven moeten (o.a.) aan weerszijden van het vuur worden geworpen (vgl. 67, 7); Wulan mogelijk met Manu, 3, 87; Viṣnu, 67, 18, waar ook Soma in de hulde betrokken wordt. Zou men nu in de beide andere woorden eveneens Javaansche aequivalenten mogen zien van in de genoemde smṛti-passages bedoelde wezens? De mogelijkheid van interpolatie is echter niet uit te sluiten. De $e k \bar{a} d a c ̧ a-$ dewatā zijn als regel de Rudra's, wind- en stormgodheden; ook 'n benaming voor de grootvaders, vgl. b.v. Manu, 3, 284 Vasūn vadanti tu piṭ̣n Rudrāṃ̣ç caiva pitāmahān | prapitāmahāṃs tathādityāñ chrutir eșā sanātanī. - De Rudra's worden ook wel beschouwd als dienaren van Çiva. Soms, zie Mbh. 12, 13043 (= 12, 342, 33) Rudro roṣātmako jāto daçānyān so 'ș̣jat svayam | ekādaçaite Rudrān tu vikārāḥ puruṣāh smṛtāh, gelden ze als modificaties van Rudra.

aweh amainan, zie boven. Vgl. b.v. Viṣṇu 67, 28 atithipūjane ca parạ̣ phalam adhitișthet, door gasten te eeren verwerft hij de hoog- 
ste belooning; 30 anāçitam atithim gṛhe na vāsayet; 32 : hierdoor verwerft hij den hemel, enz.; Manu 3, 94 vlgg. Bij karaman (over 't woord zie Jonker, Oud-Jav. Wetb., $\S \S 17,66$; p. 169) verg. men de aardige passage Viṣnı Pur. 3, 11, 56 tato godohamātrạ̣ vai kālaṇ tiṣthed gụhāngaṇe | atithigrahaṇārthāya, ,dan moet hij in zijn hof, op z'n erf, vertoeven gedurende den tijd die noodig is om een koe te melken (12 minuten) om de komst van een gast af te wachten" (Wilson-Hall III, pp. 120 vlgg.).

-18. ratu, bij 't volgende gedeelte beschik ik over weinig parallellen (zie de Inl.). Koning worden tengevolge van goede en juiste handelingen in een vorige existentie : vgl. Mārk. Pur. 10, 91 vlgg.: rājñām anyeșāñ ca mahātmanāṃ | jāyante ca kule. Zie ook 'n verhaal als van Sudyumna (Jahn, Saurap., p. 6; vgl. daar ook p. 125). Wedergeboorte van deugdzamen b.v. Br. Pur. a. 218.

-29. caru, offergerecht, met spreuken gewijd; waarvan rijst en melk of water enz. bestanddeelen zijn. Vgl. b.v. Appast. çr. sū. 8, 9, 11 vlgg.

p. 357-13. yajñakärya ${ }^{\circ}$, herinnert eenigszins aan Mbh. 12, 1217 svadharmasya parityāgạ̣ paradharmasya ca kriyā.

-17. kālpika, waarschijnlijk $\sim$ Skt. kālpaka = kālpa, een kurkumasoort; vgl. Goris, Bijdr. pp. 34 vlg. Het gebruik van safraan ontmoeten we meermalen; zie b.v. Gar. Pur. Sār. 8, 6, waar reukwerken, bloemen, safraan, tulasī (ocimum)-bloesem, lampen, spijzen, enz. tezamen genoemd worden, id. 10, 77, sandelpoeder met safraan. Zie b.v. ook Monier Williams, Brāhmanism and Hindūism, p. 91.

candana, eveneens vaak. Zie ook Goris, Bijdr., p. 35. Viṣnu 66, 2 : men geve geen ander reukwerk dan sandel etc.

-24. kaniștha - cnz., vrij vaak; vgl. b.v. Sang h. Kam., a 34, b 36.

p. 358-1. wiçz'a.jit, een offer, waarbij men 1000 koeien of zijn geheele bezit als offerloon schenkt; vgl. b.v. Jaim. br. 2, 192, Āpast. çr. sū., 22, 1, 6 b vlgg. Zie ook Kullūka op Manu 11, 1. Zie b.v. Manu, 11, 74; Mbh. 13, 4943.

-3. Sagara, enz.; beroemcle koningen uit de oudheid, voorvaderen van Rāma (vgl. b.v. Rām. 1, s. 70); over hun daden b.v. Dowson, A classical dictionary, s.s. v.v.

-6. phala, kìrti; religieuze verdienste, genot, profijt, verlossing zijn de belooningen voor hem, die een tempel bouwt. Saura Pur. 43, beg.: vgl. ook 44 beg.). Onze plaats is veel uitvoeriger.

-20. kunai, over deugden en juist gedrag van vrouwen lichten verscheidene teksten ons in; vgl. Mbh. 13, 123, 7 vlgg. (= 13, 5864 vlgg.); Manu 5, 149 vlgg. (zie ook 9, 30); Mahānirv. Tantra, 8, 102 vlgg.; 
over wedergeboorten bij ondeugden vgl. men ook Gar. Pur. Sār. 5, 26 vlgg. Vele bijzonderheden bij J. J. Meyer, Das Weib im altindischen Epos, vgl. Inhaltsübersicht en Register.

p. 359-21. kěmban tan yogya; dergelijke opsommingen van bloemen, welke men niet, en ook van bloemen, welke men wel den god moet aanbieden of bij andere gewijde gelegenheden bezigen, vinden we vaker. Vgl. b.v. Viṣnu, 66, waar 5 verbiedt: bloemen met een viezen geur, 6 bloemen zonder geur, 7 die aan dcornige planten groeien (behalve, leert 8, witte en zoet-geurende). Ook Mbh. 13, 98, 19 vlgg. (= 4696 vlgg.), een uitvoerig overzicht; $32(=4709)$ luidt: bloemen die op kerkhoven en crematoria groeien worden niet bij 'n huwelijk en derg. aangewend. Men vergelijke ook Rām. 2, 25, 28, en andere plaatsen. Zie ook Saura Pur. 65, 40 vlgg.; van zelf of door toedoen van luizen afgevallen bloemen, door anderen afgeslagen bloemen dient men in 't algemeen te vermijden. Versche, onbeschadigde, berg- en woudbloemen, vrij van ongedierte hebben de voorkeur. Hiervóór een passage over wel- of niet toelaten van bepaalde planten; zie ook Agni Pur. 202, 12 vlgg.; a. 247.

-25. sāttwika, eig. ,door sattva (een der drie guna's, zie p. 433 in deze aanteekeningen) beheerscht, daarmee in verband staande". Sattva uit zich als deugd, gemoedsrust, zelfbeheersching, vriendelijkheid en derg. Vandaar zijn verschillende vertalingen mogelijk.

p. 360-7. vijāti, vijātīya, tot een verschillende klasse, stand behoorend. Canḍāla's behooren tot de laagste en meest verachte menschen, die de Hindoe kent; de ,wetboeken” kennen ze als zoons van çūdra's met brahmaansche vrouwen (zie b.v. Viṣnu, 16, 6; Manu, 10, 12). Domba's zijn eveneens lieden van lage kaste, muzikanten en derg.

-20. Mahārūpi; Mahārūpa is een naam van Çiva; vgl. b.v. Mbh. 13, 1148 Mahārūpo Mahākāyo Vṛ̣arūpo Mahāyaçāḥ; 13, 1239.

p. 361-9. kunain tot en met pinanan, geciteerd in K. B. W. I, 529 als fragment uit het Wrihaspatitattwa.

-13. dantadhävana, een godsdienstige handeling, het „reinigen der tanden" alsook het daarvoor gebruikte houtje, waarvan nog al eens sprake is in de Voor-Indische literatuur. Vgl. J. J. Meyer, Ueber das Wesen der altindischen Rechtsschriften, pp. 197 vlg.; 275. Zich de tanden reinigen, de oogen zalven, z'n gevoeg doen, baden en de goden vereeren doe men slechts in den ochtend, leert Manu 4, 152; Viṣnu, a. 61. - Zie ook Monier-Williams, Brāhmanism and Hindūism ${ }^{4}$, p. 376.

-17. apan kapūjān; yoginī's zijn vrouwlijke wezens, met bovennatuur- 
lijke macht begaafd, in het gevolg van Çiva en Durgā. Yoginī's en dākini's zijn ,the perpetrators of all mischief” (Wilson, Essays, II, 33). In bhatrinç̧a zal wel dvātriṃçat, 32 , steken. De hier voorkomende uitdrukking voor hyan nin huntu is mij van elders niet bekend; ik vermoed echter, dat ze wel terug te vinden zal zijn.

p. 362-8. nihan cihna; vgl. b.v. Mārk. Pur. 10, 93 vlg.; Gar. Pur. Sār. 14, 84 vlg.; van schoone gestalte, rijk, alwetend, met alle çāstra's bekend is zoo'n mensch.

-14. Nihan tânak. Het hier volgende staat evenmin in het Oud-Jav. Bmọ.-Pur. Het aantal der dochters van Dakșa, die aan Kaçyapa tot echtgenooten werden gegeven bedraagt doorgaans 13. Men vergelijke b.v. Viṣnu Pur. 1, 15, 125 vlg.: Aditir Ditir Danuh Kālā Arișțā Surasā tathā| Surabhir Vinatā caiva Tāmrā Krodhavaçā Irā | Kadrur Muniç ca. Men vgl. hierbij Brahma Pur. 3, 51 vlg.; Harivamça 169 vlg.; Linga Pur. 63, 22 vlg.; Matsya Pur. 6, 1, vlg.; zie ook Mārk. Pur. 104, 4: Dakṣasya tanayā brahman tasya bhāryās trayodaça. Merkwaardig is nu, dat Vā. Pur. 66, $54(2,5,54)$ en Bmọ. Pur. 2, 3, 55 spreken van 14 dochters: yās tu çeșās tadā kanyāḥ pratijagrāha Kaçyapaḥ | caturdaça mahābhāgāh. Men zie verder de Inleiding, pp. $357 \mathrm{vlgg}$. Over de afzonderlijke namen, die eenige variatie vertoonen in de verschillende teksten: Wilson-Hall, Vishnu Pur., II, p. 26. Prawā, Wilson t.a.p.: ,the Vāyu has Pravā, in place of Arishțā", in de ed. v. d. Bibl. Ind. echter: Kālā Arișțā (noot: Dāvā A.), zoo ook Kirfel, P. P. 178, 58, - Anāyuṣā, het Skt. Bmọ. Pur. Anāyu, elders, b.v. 2, 6, 30 Anāyușā, Vāyu Pur. noot: Arișțā Nāyuṣas tatheti (sic) ; zie ook Wilson, t.a.p. Khaçā niet in het Vā. Pur., wel Bmọ. Pur. en andere teksten, echter niet steeds op deze plaats. Kadrū staat elders na Irā. Krodhā heet elders Krodhavaçā, doch Mārk. Pur. 104, 7 heeft ook den korteren naam, die in andere teksten elders ook voorkomt.

-21. Aditi, heeft kanya misschien oorspronkelijk in den tekst gestaan? (zie crit. app.). Vgl. b.v. Viṣnu Pur. 1, 15, 130: Adityā Dakṣakanyayā. Kaçyapa had bij deze vrouwen nakroost, de Aditya's, daemonen, nāga's, vogels, enz. - Vgl. b.v. Viṣnu Pur. 1, 15, 131 (Wilson-Hall, II, p. 27). De Āditya's waren in lateren tijd 12 in getal en zonnegoden. De meeste der hier opgegeven namen vindt men ook elders: Haryamā is Aryaman, Baruna: Varuna; de volgende is in Skt. Bmḍ.- en Vã. Pur., die in tegenstelling met andere teksten dezelfde volgorde hebben als ons werk, resp. 2, 3, 67 en 66, 66, Aṃça, een naam die b.v. Garuḍa Pur. 6, 42, Linga Pur. 63, 25, als 
Amçuman optreedt; ook de naam Çakra, Viṣnu Pur. 1, 15, 131 e.a., vertoont er gelijkenis mee. De volgende is elders Bhaga. Parjanya is in deze opsomming eigen aan den Bmḍ.-Vā.-tekst (Kirfel, P. P. 179, 71), of schoon hij ook Harivamça, 594 e.a. als Āditya genoemd wordt.

-23. Wizuaswān, de tegenwoordige Manu, Vaivasvata, Yama en Yamī zijn kinderen van de zon en Samjñā. De zon als Vivasvat behoort alzoo in het Vaivasvata-manvantara. Vgl. b.v. Viṣnu Pur. 3, a. 2, begin (Wilson-Hall, III, p. 20).

-31. drdhasneham, mij niet van elders bekend. Men vergelijke het critisch apparaat. Aditi wordt vaak te zamen genoemd met bevrijdende, schulddelgende godenfiguren, ook zij zelf heeft deze eigenschappen: ze is een bevrijdster uit benardheid, een heerscheres over ongedeerdheid (vgl. Oldenberg, Rel. des Veda, pp. 202 vlgg.); welwillendheid en moederlijkheid zijn karaktertrekken van haar (vgl. Macdonell, Vedic Myth. § 41; Hopkins, Epic Myth. § 37).

p. 363-3. dewatā, vgl. Manu 5, 154: ,zelfs een slechtaardig echtgenoot, die geen deugden bezit, moet door een trouwe vrouw als een god vereerd worden". Vgl. ook Mbh. 13, 146, 6.

-18. Diti, vgl. b.v. Viṣnu Pur. 1, 15, 140; zie Wilson-Hall, II, p. 30; Skt. Bmḍ. Pur. 2, 5, 3; Vā. Pur. 67, 49 e.a. De reuzen en daemonen Daitya's zijn de afstammelingen van Diti. Hiranyakaçipu is bekend wegens z'n strijd tegen Viṣnu, dien z'n zoon Prahlāda vereerde; de god doodde hem als Narasiṃha (vierde avatāra).

-22. Simhikā, vgl. b.v. Skt. Bmḍ. Pur. 2, 5, 12; Viṣnu Pur. 1, 15, 141 e.a.; vlg. Bmụ.: Siṃhikā tasya cânujā | Rāhoh sā jananī devï Vipracitteh parigrahah. - Rāhu is de daitya, aan wiens toedoen men zonsverduisteringen toeschrijft. - Vipracitti is een zoon van Kaçyapa en Danu, derhalve een der Dānava's, reuzen, vijanden der goden.

-24. Hiranyakaçipu: Hiranyakaçipoh putrāç catvārạ - | Prahrā(var. -hlā-)dah pūrvajah teșām Anuhrā(als voren)das tathaiva ca || Saṃhrādaç caiva Hrādaç ca, Vā. Pur. 67, 70; Bmọ. Pur. 2, 5, 33 (waar tathāparas i.p.v. tathaiva ca).

-27. Wirocana, vgl. Vā. Pur. 67, 76 Virocanas tu Prāhrādih pañca tasyātmajāh smṛtāh | Gaveșṭī Kālanemiç ca Jambho Bāṣkala eva ca | Çambhụ șașțho 'nujas teșām, smṛtạ̣̄ Prahrādasūnavah. Prahlāda geldt algemeen als de vader van Virocana.

Men merke op, dat de Voor-Indische Purāna-teksten hier uiteengaan; de eerste groep heeft: Virocanaç ca Prāhrādir, Balir jajñe Virocanăt (Vi. Pur. 1, 21, 1 e.a.; Kirfel, P. P. 165, 70), groep Ia (Bmḍ.-Vā.) zie boven, groep II (Matsya Pur. 6, 9 e.a.; P. P. 215, 
9) : Prahlādaputra Āyuṣmāñ Çibir Bāṣkala eva ca | Virocanaç caturthaç ca. Ook het Agastyaparwa heeft een andere lezing; vgl. vooral r. 27 waar Hrāla onjuist is; zie echter ook p. 366, r. 29 en 30. - Merkwaardigerwijze spreekt onze tekst van 7 zoons. (H) ndug Basur is geen figuur uit de Voor-Ind. mythologie; de tekst brengt hem met Java in verband, dat hij gekweld, geteisterd zou hebben. Ik voel mij hier herinnerd aan de figuur in de Soendasche Wawatjan Soelandjana (ed. C. M. Pleyte, 1907; inhoudsoverzicht bij K. A. H. Hidding, Nji Pohatji Sangjang Sri, Diss. Leiden, 1929, pp. 9-18; vgl. ald., p. 5). Hier is Boedoeg basóe een dier met hondekop en hondegedaante, als kind aangenomen (met Kala boewat) door den dierenvorst Sapi goemarang, die een langdurigen en hardnekkigen strijd voerde met Soelandjana c.s., zoon van Dewa Wěnang, daar hij de rijst, die pas aan de menschen was geschonken en groote welvaart veroorzaakte met alle geweld wilde vernietigen, waarbij Boedoeg Basoe hem trouw ter zijde stond. In de Oud-Soendasche kroniek Tjarita Parahyangan wordt dezelfde figuur genoemd (zie Pleyte, De legende van den Loetoeng Kasaroeng, Verh. Bat. Gen., 58, III, p. XIX); doch daar luidt zijn naam Sang Oedoebasoe. In onzen tekst is H. B. kleinzoon (stond er oorspr. $k a k a$, hoe anders pitu te verklaren?) van Kālanemi, wiens optreden in de Voor-Indische traditie overeenkomst vertoont met dat van H. B. in de bovengenoemde rijstmythe. Men vindt het verhaal Viṣnu Pur. 5, 1, 12 vlgg. : de Aarde begeeft zich naar den Meru en beklaagt zich in een godenvergadering er over, dat Kālanemi en vele andere daemonen de menschenwereld teisteren; niet in staat zich zelf van dezen overlast te ontdoen, komt ze om hulp vragen. De invoeging van de figuur van $\mathrm{H}$. B. op juist deze plaats behoeft ons dus niet te bevreemden.

In de Oud-Jav. literatuur komt voor Wuḍugbasu (vgl. Soend. Boedoeg Basoe!), n.1. in het Korawāçrama (bij Pigeaud, T. P., p. 331, waar er een godheid mee bedoeld wordt, die met Bhațāara Kāla het wezen van den Kaurava Duryodhana zou vormen. Voorts verg. men: Pigeaud, T. P., p. 290 (uit het Dewaçāsana) Wudug-asu, e.a. („Honde-schurft”). - In Goris' hs. : Udug Basul.

-30. Balirāja, d.i. Bali, die het gezag over de drie werelden verworven had, doch dat over hemel en aarde weer verloor: Viṣnu als dwerg vroeg hem zooveel grond als hij in drie stappen kon overschrijden; in twee stappen doorschreed de god hemel en aarde (Vāmanaavatāra). Oindat Bali echter steeds goed en deugdzaam was geweest, 
liet hij hem de onderaardsche wereld; hij is dan ook vorst in de Pātāla. Zie Bhāg. Pur. 8, 15-23.

p. 364-3. daitya satus, vgl. Skt. Bmḍ. Pur. 2, 5, 41; Vã. Pur. 67, 82 : Baleh putraçatạ jajñe; het voorafgaande ontbreekt in deze beide teksten. - Pradhāna: ald. resp. vs. $42 ; 83$ teșām pradhānāç catvāro vikrāntāh sumahābalāh. De andere tekstgroepen van Kirfel zijn veel beknopter (P. P. 165, 70; 215, 10) Baleh putraçatạ̣ tv āsīd Bānajyeștham etc.

-5. Bāna-rodra ${ }^{\circ}$. Het volgende niet in Bmḍ.-Vā. e.a. Waarschijnlijk is rodratantrârādh ${ }^{\circ}$ in z'n geheel citaat; slechts het tweede schijnt in het Oud-Jav. te zijn weergegeven.

Volgens b.v. Saura Pur. 30, 5 vlgg. kreeg Bāṇa als belooning voor z'n Çiva-vereering het gānapatya (Schaarführerschaft). Nandīçwara $=$ Nandi, leider van het gevolg van Çiva.

-9. Kumbhanābha, overeenstemming met den Bmḍ.-Vā.-tekst (vgl. Kirfel, P. P. 197, 37) : Kumbhanābho Gardabhākṣah Kukṣir ityevamādayah.

-11. Çakuñ̄ Pūtanā caiva kanye dve (Bmạ.-Vā., resp. vs. 43, 84). Het volgende ontbreekt daar; vgl. Viṣnu Pur. 5, 5, 6 vlgg., in de vertaling van Wilson, IV, p. 276. Pūtanā zoogde 's nachts kinderen, tengevolge waarvan ze stierven; zoo nu ook den jongen Kṛșna, die echter zoo hard zoog, dat P. omkwam. Dit geschiedde te Gokula (vs. 7), even verder Vraja (vs. 11) genoemd, de verblijfplaats van den koeherder Nanda, bij wien Krṣna opgroeide; onze tekst leest dus Govraja, welk woord b.v. Hariv. 3509 e.a.

-13. Prahlāda, de vereerder van Viṣnu, was vijandig gezind aan Indra. Viṣnu Pur. 1, 20, 34, valt hem, na koning der daitya's geworden te zijn, de uiteindelijke verlossing ten deel; Saura Pur. 30, 11 wordt hij yogin. Mbh. 12, 98, 49 noemt Indra hem op onder degenen die hij gedood heeft.

Diti wilde weer 'n zoon die Indra zou dooden; Kaçyapa stond haar dit, onder voorwaarde van 100-jarige zwangerschap, toe. Indra, dit wetende, kwam in het laatste jaar en deelde het kind in haar schoot in zevenen. Het kind schreeuwde; daarna spleet hij de 7 deelen nog eens in zevenen. Zoo ontstonden de 49 Maruts, Stormgoden. Zie b.v. Viṣnu Pur. 1, 21, 29 sqq. en uitvoeriger b.v. Skt. Bmḍ. Pur. 2, 5, 45 sqq.; Vã. Pur. 67, 85 sqq. - Puramdara in dit verband slechts in het Vā. Pur. (vs. 102); de naam wordt daar niet verklaard. Gewoonlijk wordt hij opgevat als „Burchtenvernietiger”. - Indraantaka, in de Skt. teksten anders uitgedrukt (Indravadhārthāya, b.v. D1. 92. 
Viṣnı̣ı Pur. 1, 21 31; Çakrahantāram, b.v. Vā. Pur. 67, 89 enz.). natgata, zie Bijdr. Kon. Inst., 88, pp. 462 vlgg.

pura (zie boven); pur en pura beteekenen behalve ,burcht, stad” ook ,lichaam”. - Onze tekst geeft het verhaal in 't kort weer.

-25. anainis ta sira; in de genoemde Skt. teksten is het de garbha, tot wien Indra zegt: mā rodīh (vd. het woord Marut). Het citaat paçyann enz. heb ik daar dan ook niet gevonden.

p. 365-2. brahmahaty $\bar{a}$, het dooden van een brahmaan is een doodszonde; zie b.v. Manu 9, 235: brahmahā ca surāpaç ca steyī ca gurutalpagaḥ ete sarve pṛthag jñeyā mahāpātakino narāḥ $\|$; vgl. 11, 55.

-4. bliunnahan of bhrūnaghna is een embryo-dooder. Het misdrijf, bhrūnahatyā wordt in Skt. teksten zeer zwaar gerekend en met brahmanenmoord, waarvoor de uitdrukking wel gebezigd wordt, gelijkgesteld; men vgl. b.v. Vās. dh. ç. 20, 23. Voor bijzonderheden: J. J. Meyer, Das Weib im altind. Epos, p. 278. Het volgende citaat wekt herinneringen aan Manu 11, 87 : hatvā garbham avijñātam etad eva vratạ̣ caret (n.1. als voor brahmahatyā) | rājanyavaiçyau cejānāv ātreyīm eva ca striyam. Vgl. voorts Viṣnu 36, 1; Yājñ. 3, 251; Vās. 20, 34; A past. 1, 9, 24, 6 vlgg. Daar is sprake van het dooden van 'n embryo, van 'n offerenden kṣatriya of vaiçya, van 'n Brahmaansche zwangere vrouw, van 'n menstrueerende of een die zich juist na tijdelijke onreinheid gereinigd heeft (ātreyī), en Āpast. 1, 9, 24, 24 ook van een guru. - Zeer merkwaardig is het hier de koe met genoemde personen op één lijn te zien gesteld, daar de geciteerde parallellen deze hier niet vermelden. Zooals men weet is de ,heiligheid”, de onschendbàarheid van de koe bij de Indiërs in den loop der eeuwen toegenomen. In den oudsten tijd had men eerbied voor het dier. De oudere Dharmaçāstra's stellen het dooden van 'n koe met dat van 'n çūdra gelijk, latere met dat van 'n vaiçya; bijzonderheden bij J. J. Meyer, Wesen altind. Rechtsschr. pp. 45-47. In lateren tijd, vooral bij de Visnuiten, is de absolute onschendbaarheid van de koe regel geworden: het dooden van 'n koe is geworden tot een vreeselijke misdaad, slechts door den dood van den dader te zoenen. Men zie b.v. M. A. Muusses, Koecultus bij de Hindoes, Diss. Utrecht, 1920, passim; Glasenapp, Hinduismus, pp. 67 vlgg., Dubois-Beauchamp, Hindu Manners, p. 194. Voor de dateering van onzen tekst kunnen we dit gegeven niet gebruiken. We leeren er weliswaar dit uit, dat hij (d.w.z. z'n Sanskrit voorbeeld) jonger is dan genoemde smrti-teksten, doch dit zegt weinig. Ook Mbh. 13, 74, 4 (= 3609) staat : ,hij die 'n koe... doodt... (himsyād) ... gaat 
naar de hel (majjati) voor zooveel jaren als de koe haren heeft".

-8. kalinanya, de explicatie van het vers woord voor woord, op ,primitieve" wijze.

-12. ācārya: de guru, geestelijke leidsman, van wien verder in dit geschrift nog sprake is. Pañcakama ${ }^{\circ}$, zooals de hss. geven is foutief. Op p. 396; 399 is sprake van pañcakarma (vgl. ook K. B. W. IV, 288a; 875b). Pañcakarma zijn de vijf karmāṇi, ceremoniën, sacramenten (saṃskāra), die de initiatie (dỉkșā) vormen; ook elders, vgl. b.v. Schrader, Pāñcarātrā, p. 112. Men zal wel niet te denken hebben aan pañcakrama, de vijf krama's, de vijf stadia ,(les) cinq états successifs dont le dernier terme est la possesșion complète et définitive des samādhis de l'anuttarayoga". Vgl. De La Vallée Poussin, Pañcakrama, p. XI (waarover Winternitz, Gesch. d. ind. Litt. II, p. 275).

-18. Çatakratu (,honderdvoudige geestkracht hebbend”) = Indra.

-19. mamintakasih enz.; onze tekst knoopt hier - anders dan de vergeleken parallellen - aan de geschiedenis van Indra, Diti en de Maruts die van Indra's brahmahatyā (schuld van het dooden van een brahmaan) aan, welbekend uit het verhaal van het dooden van Vṛtra (die den Veda kende en wiens dood brahmahatyā veroorzaakt) door dezen god. Het oude verhaal (zie beneden) leert, dat Indra, nadat hij Vrrtra gedood had (vgl. b.v. Hopkins, Epic Myth., § 72), bezoedeld werd met de vreeselijke zonde van brahmanenmoord; hij vluchtte toen, in angst, naar het einde der wereld, ging de wateren binnen en verborg zich. Tenslotte ontdekten de goden waar hij was, reinigden hem van zonde door een paardenoffer, waarna hij weer heerscher van den hemel werd (vgl. Mbh. 5, a. 10 vlgg.). Mbh. 12, 283, 11 vlgg. (= 10154 vlgg.) komt de brahmahatyā als een afzichtelijke, vreeselijke vrouwegestalte uit V.'s lijk; ze bleef bij Indra, die in 'n lotusstengel binnenging, en zich daarna tot Brahmā wendde om hulp; deze plaatste $1 / 4$ van de brahmahatyā in Agni (het vuur), $1 / 4$ in de boomen, kruiden en grassoorten, $1 / 4$ in de apsarasen, $1 / 4$ in de wateren. Mbh. 12, a. 344 bevat het verhaal weer anders: de goden en ṛsị's wendden zich tot Viṣnu om hulp voor Indra; de brahmahatyā werd verdeeld onder vrouwen, vuur, boomen en runderen (13217). Rām. 4, 24, 14 wordt ze verdeeld onder aarde, water, boomen, vrouwen. Vgl. ook Rām. 7, 84, 3 vlgg.; Mbh. 5, 13, 19.

-24. lawe, het verhaal van deze kaluin ken ik niet van elders.

p.366-7. kunain mukhya. Het is reeds een oude en veel-vermelde voorstelling bij de Hindoes, dat een gedeelte $(1 / 3$ of $1 / 4)$ van de schuld 
wegens brahnnanen-moord van Indra door de vrouwen overgenomen is, tengevolge waarvan deze iederen maand bloed laten vloeien; de brahmahatyā, hiermee naar buiten komend, neemt daarbij af ; „vrouwen hebben daarin een weergaloos middel tot reiniging" (dit b.v. Baudh. dh. ç. 2, 2, 4, 4: striyaḥ pavitram atulạ̣ naitā duṣyanti karhicit | māsi māsi rajo hy āsām duritāny apakarṣati). Hoe Indra, na Vrtra gedood te hebben (zie boven), zijn schuld voor een deel overdeed, wordt verteld: Taitt. Saṃh. 2, 5, 1, 2 vlgg., Çat. Br. 1, 2, 3, 2; Vāsiṣtha Dh. ç. 5, 7 (8) ; Rām. 7, 86, 16; Bhāg. Pur. 6, 9, 9. De vrouwen kregen, doordat ze Indra dezen dienst bewezen, van hem de gunst, dat ze tijdens de geschikte periode (rtu) bij hun mannen zwanger zouden worden. „Daarom ete men niet het voedsel van een vrouw gedurende haar menses, want een dergelijke vrouw heeft de gedaante van de brahmahatyā aangenomen” (b.v. Vās. 5, 7/8): tasmād rajasvalāyā annam nāçnīyād bhrūnahahatyāyā evaiṣā rūpạ̣ pratimucyāste). Dit verbod ontmoeten we dan ook herhaaldelijk, vgl. b.v. Manu 4, 208: voedsel door een moordenaar van 'n geleerden brahmaan, door een menstrueerende vrouw, door vogels of door honden aangeroerd ete een brahmaan niet; vgl. ook Viṣnu 51, 17; Yājñ. 1, 168; Gautama, 17, 10, e.a. Heeft men een vrouw in dien toestand aangeraakt, dan neme men een reinigingsbad (Manu 5, 85; Vās. 4, 37, e.a.), evengoed als na het aanraken van 'n lijk. Met haar dan den bijslaap uit te oefenen, geldt voor bijzonder gevaarlijk; op iemand, die dat doet, zal de schuld voor brahmanenmoord terstond overgaan (Meyer, Weib, p. 169; vgl. ook Manu 4, 41 e.a.). Aan het bloed kleven „,magisch gevaarlijke” eigenschappen (vgl. b.v. Kauțilīya Arthaçāstra, in Meyer's vert., p. 648, 15 vlgg.), kinderen, die dan geconcipieërd zouden worden, zullen of gebrekkig zijn, of kort leven (vgl. Jolly, Medizin, p. 50), of booswichten worden (zoo b.v. Gar. Pur. Sār. 6, 3). Verbodsbepalingen daartegen vinden we dan ook meermalen, b.v. Manu, 4, 40, vgl. 11, 174; Gaut. 9, 29. Vaak vinden we ook het spreken met zoo'n vrouw verboden: Viṣnu 71, 58; Manu, 4, 57. Vier dagen lang moet ze vermeden worden, b.v. Manu, 3, 47; Gar. Pur. Sār. 15, 7. Wat de vrouw dan zelf in acht moet nemen (b.v. niet in het water baden, op den grond slapen, geen vuur aanraken, niet lachen), b.v. Vās. Dh. ç. 5, 6 (7). Natuurlijk zijn er ook hellestraffen op overtredingen gesteld, b.v. op 't eten van spijs van dergelijke vrouwen: rajasvalānnam yo bhunkte dvijo jñānāt sakṛd yadi | rauravaṃ narakam yāti sa bhavet sadvigarhitạ (bij Hemādri, IV, p. 435). Zooals bekend heeft de maandelijksche 
periode de gedachten en fantasie van vele volkeren beziggehouden, en zelfs in modernen tijd in West-Europa zijn nog gevallen van overeenkomstig geloof bekend. Zie b.v. het verhaal, hoe door 'n samenloop van omstandigheden op een Engelsche meisjeskostschool noch de kookster, noch de directrice, noch een der leeraressen het vleesch kon bereiden, bij J. J. Meyer, Das Weib im altindischen Epos, pp. 170, n., waar ook andere bijzonderheden.

-13. larainan, zij is dus agamyā; vgl. b.v. Manu, 11, 174 met 170; de hss. interpungeeren vóór ika.

-14. strī kumiin, tegen sexueel verkeer met zoo'n vrouw b.v. Mbh. 13, 129,$2 ; 4$ (6088; 6090). Volledig ontbreken van de menstruatie en dientengevolge onvruchtbaarheid (bandhyā, șaṇịi, vgl. J. Jolly, Medizin, Grundriss. p. 67) werd gevreesd; als middel er tegen askese en tooverij (vgl. Meyer, Weib, pp. 118 vlgg. e.a.).

-18. kabayan; vgl. Aichele, Zeitschr. f. Eing. Spr. 21, 3; Djåwå, 11, 147 vlgg.; ook Bijdr. 90, 163 en daar genoemde literatuur. Nadien nog: Dr. L. M. Coster-Wijsman, Bijdr., 90, pp. 141 sqq.; een artikel van Berg Bijdr., 90, 603.

-20. Thans keeren we terug tot de Daitya-genealogieën. Widyutkeça; Vā. Pur. 67, 77: Viṣkaksena (Kirfel, P. P. 197, 31, 4: Vișvo ${ }^{\circ}$. Widyutkeșa ook Rām. 7, 4, 17. Elders 3 namen, $\mathrm{Mah}^{\circ}$ is mij verder niet bekend.

-23. Brahmajit Kṣatrajic (Vā.; Kratujic Bmọ.) caiva DevāntakaNarāntakau | Kālanemisutā hy ete, Vā. Pur. 67, 80; Bmụ. Pur. $2,5,39$.

-25. Jambu, elders Jambha, met 4 kinderen, waarvan Çatadundubhi een is (Bmḍ. Pur. 2, 5, 38).

-26. Walkāla, Virodha en 3 anderen: Vā. Pur. 67, 79.

Sambhu heeft in Skt Bmḍ. en Vā. P’ur. meer kinderen; Vã. noemt o.a. (vs. 81) Dhanuka; 68, 51 echter Dhenuka.

-31. Hräda; de hier genoemde Mayu ken ik van elders in dit verband niet. Er is wel een kimpuruṣa van dien naam; zie P. W., s.v. De teksten gaan hier uiteen: groep I heeft: Hrādaputro Hradas tathā (Kirfel, P. P. 165, 69) ; Bmḍ. Pur. 2, 5, 34 Sundo Nisundaç ca tathā Hrādaputrau --; Vā. Pur. 67, 71 Hrādo Nisundaç ca tathā Hradaputrau.

-32. Anuhrāda. Hier is verschil met de Skt. Purāṇa's en het Mahābhārata. Daar wordt gesproken van de Nivātakavaca's, 30 milj. Dānava's, die in de diepten der zee woonden; zij zijn meestal zoons van Saṃhrāda, niet van Anuhrāda. Zie b.v. Brahma Pur. 3, 90 sq. 
Saṃhrādasya tu daityasya Nivātakavacāḥ kule | samutpannāh... | tisrah koṭah sutās teṣām Mạ̣ivatyām (zie beneden) nivāsinaḥ | . . Arjunena nipātitāh. Zie ook Mbh. 3, 96, 4. Hier ziet men dus, dat niet alleen in de Oud-Jav. Arjuna-Wiwāha de Niwātakawaca's tot één reuzenkoning gemaakt zijn (vgl. Poerbatjaraka, Arj.-Wiw., overdruk, p. 3), al blijkt het hier eigenlijk slechts uit makādi, dat evenwel een meervoud, te beginnen met de N.'s, m.i. niet uitsluit.

p. 367-4. Manimāntaka: de Skt. teksten (Mbh. 3. $8543=3$, 96, 4 e.a., zie ook boven) heben Manimatī. De Arj.-Wiw., 16, 6 e.a. echter als onze tekst.

-5. Suprabhā wordt in de Purāna's en het Mbh. in dit verband niet genoemd. Vgl. wederom den Arj.-Wiw.

-6. Hrāda : volgens den Harivamça 217 was Mūka 'n zoon van Hrada; in den Har. had hij een broer Tuhunḍa; in het Bmḍ. Pur. had hij Sunda en Nisunda als broers, in het Vā. Pur. Hrāda en Nisunda; deze twee teksten noemen hem $(2,5,35 ; 67,72)$ Hrā(a)dadāyaka. Van dezen Mūka wordt in het Mbh. verteld (3, 1557 vlgg. $=3,39$, 12-14), dat hij door Arjuna, die tegelijk met Çiva in de gedaante van 'n Kirāta z'n pijl afschoot, werd gedood. Bmọ.- en Vā. Pur. noemen even zijn dood door Arjuna: Mūko vinihataç cāpi Kairāte Savyasācinā. Voorts verg. men Arj. Wiw. 7, 3 enz. - Bhațtāara: Çiwa, vgl. Mbh., t.a.p.; Arj. Wiw. 8, 8. - Over het zwijn (de naam si D. komt in den Arj. Wiw. niet voor en is niet van Voor-Indische origine) vgl. men K. B. W. II, 520. Zie voorts IV, 549; Pigeaud, T. P. p. 219 en elders (zie boven, Inleiding, p. 387, n. 2).

-9. parwa heeft hier waarschijnlijk de engere beteekenis: het prozaverhaal; mogelijk is bedoeld het Mahābhārata-boek, waarin de gebeurtenissen verhaald zijn, d.i. het derde, Vanaparva. Hierbij wellicht te vergelijken: Mededeelingen van de Kïrtya Liefrinck-Van der Tuuk, I, p. 36. Er wordt hier geen gewag gemaakt van den ArjunaWiwāha. Over eventueele dateeringsmogelijkheden op grond van deze plaats zie de Inleiding, p. 387.

-12. Sunda: den tweeden naam ken ik zoo niet van elders.

Men vgl. Harivamça 218 Mārīcah Sundaputraç ca Tāḍakāyām vyajāyata, vgl. Bmḍ. Pur. 2, 5, 35.De naam luidt in Voor-Ind. teksten als regel met -d-; de wisseling van -d- en -t- is in het Sanskrit bekend (tātaríka - tāịanika e.a.) ; in het Jav. met -t-t; zie ook K. B. W. II, 659.

-15. Rāma doodt T.; zie Skt. Rām. 1, 26, 26; O.-J. Rām. 2, 23-27; Sĕrat Rama 2, 2. 
-16. Gādhiputra, d.i. Viçvāmitra, vgl. O.-J. Rām. 1, 38. yekânak, dus: yeka ânak.

Mārīci, in Voor-Ind. en Jav. teksten doorgaans Mārīca.

-18. Janakaputrikā, Sītā, echtgenoote van Rāma, dochter van Janaka, koning van Videha. Mārīci bewoog, in 'n gedaante van 'n gouden ree, Rāma, Sìtā te verlaten; intusschen werd ze door Rāvaṇa geroofd. Vgl. Rām. 3, 43 vlgg.; Oud-Jav. Rām. 5, 38 sqq. Vā.- en Skt. Bmọ. Pur. spreken even over zijn dood: 67, 73; 2, 5, 36: Danḍake (het D.-woud) nihatah so 'tha Rāghavena balīyasā.

Pañcawadi, in den Voor-Indischen vorm Pañcavațī (vgl. Rām. 3, 13, 17; enz.) dicht bij de Godāvarī, waar Rāma zich neerlaat.

-21. Sundopasunda: Sund-Opasundau vikrāntau Nisundatanayāv ubhau, Vā. Pur. 67, 71. Het Skt. Bmḍ. Pur., 2, 5, 34, heeft, hiervan afwijkend: Sundo Nisundaç ca tathā Hrādaputrau babhūvatuh. Mbh.

1, 7621: Sunda en Upasunda zoons van Nikumbha.

Het hier volgende staat hier niet in Skt. Bmọ.- en Vā. Pur.

-26. Tilottamā, vgl. voor deze geschiedenis Mbh. 1, adhy. 211; O.-J. $\bar{A}$ dip. pp. 192 sqq. Onder de bekoring van Tilottamā, een opzettelijk tot dat doel geschapen wonderschoone vrouw, krijgen deze twee tot dusver eensgezinde broers, die de heerschappij over de drie werelden voor zich opeischen, ruzie en dooden elkaar.

de nin prajñopaya, d.w.z. geestelijke vaders.

-30. Hiranyākșa's zoons zijn 1) Ūrjara (Brahma Pur. 3, 72, noot), Utkura (Vi. Pur. 1, 21, 3; Vā. Pur. 67, 67), Ulūka (Matsya Pur. 6, 14 e.a.) ; 2) Ç.; 3) K.; 4) Mahānābha; 5) Bhūtasaṃtapana (volgorde v. d. Bmụ.-Vā.-versie). Van 4 en 5 is in onzen tekst (wsl. later, vgl. lima) één gemaakt. De toevoeging ndatan enz. staat in deze werken niet.

p. 368-3. wěka sain S.; het aantal zoons varieert, het Viṣnu Pur., 2, 21, 10 sq., Wilson-Hall, II, p. 71, noemt er 12, meestal (b.v. Brahma Pur. 3, 87 sqq.) vindt men er 13, soms, als hier, 14, b.v. Bmḍ. Pur. 2, 6, 18; Vā. Pur. 68, 18. De namen vertoonen weer eenige bijzonderheden. Uit vergelijking met Sanskrit Purāna's (zie Wilson-Hall, II, 71, doch vooral Kirfel, P. P. 168, 91; 205, 19; 216, 26) blijkt, dat een aantal namen hier en ginds (ook in de Voor-Indische bronnen vindt men een aantal onderlinge verschillen) overeenstemt. De volgende vertoonen bijzonderheden: no. 1, Ailera, correspondeert met wie?; no. $2 \sim$ Çatagāla of Çataçālya van Vā. Pur. 68, 18?; no. 3, voor Vyamça of Vyamsa; no. 4, ginds Çalya of Sala; no. 5, Baka, wiens naam het meeste gelijkt op Nala (Brahma Pur. 3, 87), 
Nabha (Harivamça 215 e.a.), Bala (Çiva Pur., Dh. s., 54, 63). Merkwaardigerwijs wordt deze Baka uitdrukkelijk geidentificeerd met den reus B. in het $\bar{A}$ diparwa, vgl. Mbh. 1, 160, 7.

-6. Cakramandala, vgl. O.-J. Addip. pp. 147; 148: Ekacakramaṇdala, Mbh. I, 6094; 6928 Ekacakrā.

No. $6-8$ overal eender, no. 9 herinnert aan Bmḍ. Pur. 2, 6, 19 Supuñjika (Vā. Pur. anders, cf. 68, 19); no. 10 is elders Harakalpa (Bmḍ.-Vā.), no. 11 Kãlanābha (in alle drie groepen Purāna’s), no. 12, ? ( $\sim$ Bhauma in Bmḍ.-Vā., de volgende is daar Kanaka); no. 13 ook Viṣnu Pur. 1, 21, 11 e.a., niet Bmọ.-Vā.; Rāhu ook in vele andere teksten: Rāhur jyeșthas tu teșām vai sūryacandrapramardanah.

-11. Prabhā: ze is in de Skt. Purāna’s de dochter van Svarbhānu, vgl. b.v. Viṣnu Pur. 1, 21, 6, Wilson-Hall, II, p. 70. Ze is daar soms ook de moeder van Nahuṣa: Hariv. 212, Vā. Pur. 68, 24 e.a. Volgens Wilson leert het Bhāg. Pur. 6, 6, 31 dat ze de vrouw was van Namuci; er staat echter (vs. 32) Svarbhānoh Suprabhāṃ kanyām uvāha Namucih kila. Elders, b.v. Viṣnu Pur. 4, 8, 1, huwde Āyus, de oudste zoon van Purūravas, de dochter van Rāhu; een zijner zoons was Nahuṣa. Zie Wilson-Hall, IV, p. 30. De hier genoemde Svarbhānu wordt echter geïlentificeerd met Rāhu, b.v. id., V, II, p. 205. Zie ook $\bar{A}$ dip. p. 73, 11: $\bar{A} y u$ makastrī sang Pradhu (sic) mânak ri sang Nahuṣa. N. was een koning, over wien het Mbh. meermalen spreekt; zie vooral $5,11-17$ : hij had groote macht en vernietigde de daçyu's, dwong echter de ṛ̣i's hem als lastdieren op den rug te dragen, ja zelfs voerde hij in plaats van Indra een tijd lang het bewind in den hemel. Daar spande hij de ṛ̣i’s uit den hemel voor z'n wagen en trad Agastya met z'n voet op diens hoofd. Dit was te erg: A. vervloekte hem; hij viel uit den hemel en werd 10000 jaren slang; door Yudhișthira werd hij tenslotte verlost (Mbh. 3, 179 sqq.).

-19. makastrī: vgl. Vāyu Pur. 93, 12 (= 2, 31, 12); Brahma Pur. 12, 1; Hariv. 1599 e.a. Nahuṣasya tu dāyādāḥ șạ̣ indropamatejasah | utpannāh pitṛkanyāyāṃ Virajāyām mahaujasah. Vgl. ook Vị̣nu Pur. 4, c. 10; Wilson-Hall, IV, pp. 45 sqq. - Yayāti's twee vrouwen (Devayānī en Çarmișthā) ook elders; vgl. de genoemde teksten eenige regels verder. - Çukra, aldaar Uçanas genoemd; de planeet Venus en z'n bestuurder. Hierna is $i$ ingevoegd: Jayantī, Indra's dochter is Çukra's vrouw; zie b.v. Vā. Pur. 97, 149 vlgg. Wrṣaparwāa: Vṛ̣aparvan der genoemde teksten. - Upādanavī is 
gewoonlijk een dochter van Vṛ̣aparvan; zie b.v. Vișnu Pur. 1, 21, 7; anders (doch niet zooals hier) b.v. Matsya Pur. 6, 21. - De naam Çarmișthā is gecorrigeerd, daar de overgang ar $>$ rě zeer veelvuldig voorkomt.

-22. Yadukula. Misschien is de tekst corrupt (lacuneus). Devayānī had een zoon Yadu; van hem stamden de Yãdava's; zóó de gewone lezing. Vrrṣni is een van de afstammelingen van Yadu. Men zie over deze figuren Pargiter, Anc. Ind. hist. trad., p. 86 vlg. en de daar genoemde teksten. - V rsṣni en Andhaka zijn twee broeders, zoons van den Yādava Sātvađa; zie Pargiter, o.c., pp. 87; 102 vlgg., vooral de tabellen op pp. 105; 107; Krṣna stamt, zooals men daar voor oogen vindt gesteld, af van Vṛ̣ṇi. Pāṇụawa, vgl. echter Pargiter, o.c., p. 294.

-24. Çacì, vgl. Brahma Pur. 3, 80 (Pulomnas tu Çacī sutā) met Vā. Pur. 68, 24 (Jayantaç ca Çacisutah).

Pulomā: Puloman der Skt. teksten. Çacī (Paulomī) was gehuwd met Indra, zoon Jayanta. Bijzonderheden bij Hopkins, Epic Myth., $\S 82$, en elders.

-28. Danu, de lijst der kinderen van Kaçyapa en Danu varieert in lengte. Vgl. Viṣnu Pur., 1, 21, 4 vlg.; Bhāg. Pur. 6, 6, 29 vlg. en andere teksten (Kirfel, P. P. 166, 74 vlgg. e.a.). Sommige teksten noemen het getal 100 (anders Mbh. 1, 2529) : b.v. Brahma Pur. 3, 73 abhavan Danuputrāç ca çatạ̣ tīvraparākramāḥ, Bmọ. Pur. 2, 6, 1; Vā. Pur. 68, 2. De oudste, voornaamste, is Vipracitti: Linga Pur. 63, 28 V. pradhāno 'bhūt teșām ; vgl. Bmḍ. Pur., t.a.p., e.a., Mbh. 1, 2529; vg1. O.-J. Ädip. p. 64, 4.

-29. Dwipajña: elders een Dvimūrdhan; het tweede deel van dezen naam is hier met den volgenden (?) gecombineerd.

-30. Ajamuka: elders Ayomukha. Daarna in 2 teksten (Garuda Pur. 6, 47 en Viṣnu Pur. 1, 21, 4) Çańkuçirah, die in enkele andere bronnen iets eerder, elders (o.a. Bmḍ.-Vã.) niet genoemd wordt; hieruit is de lezing van onzen tekst licht te verklaren. San Kura is misschien zoo ontstaan uit Çañkur (Bmọ. Pur. 2, 6, 4; Vā. Pur. $68,4)$, dus voor Çanku; niets belet ons, deze namen weder als één woord te schrijven; de bewerker zal ze niet hebben misverstaan. Mahān wellicht de Maghavān van Bmọ. Pur. 2, 6, 5; Brahma Pưr. 3, 75 e.a. Sañkukarṇa Bmụ.-Vā., Brahma Pur. e.a. De volgende zal Vipāda (Bmọ.-Vā., elders anders) zijn. Hierna in vele teksten Gaveșți; Vā. Pur. 68, 16 (andere plaats) spreekt van Gaveșțiç ca Gavākșah ; misschien op onze plaats ingedrongen? 
-31. Duloma: in enkele teksten volgt nu Dundubhi, echter gelijkt het meest op dezen naam Pulomā (Puloman), b.v. Vāyu Pur. 68, 7; Bmḍ. Pur. 2, 6, 7 ; Viṣnu Pur. 1, 21, 5. Zie ook Mbh. 1, 2530. Het merkwaardige is, dat ook het O.-J. A dip., p. 18, dezen naam P. (Mbh. I, 877) met Duloma weergeeft.

p. 369-1. kaki san $W$.; is deze W. misschien de door Matsya Pur. 195, 15 genoemde $\bar{A}$ pnuvāna, broer van Cyavana, zoon van Bhṛu en Puloman's dochter Divyāi ? Kapila, ook Bmḍ.-Vā. Padma Pur. 1, 6, 50, Brahma Pur. 3, 75 e.a. Bhamana: Vāmana van 'n aantal andere teksten. De volgende naam is behalve in F verknoeid uit Maya, de vader van Mandodarī, Rāvaṇa's voornaamste vrouw. Hij wordt ook genoemd Hariv. 203; het dichtst bij onzen tekst staat echter Bmc!. Pur. 2, 6, 5 Ayomukhas tu Maghavān Kapilo Vāmano Mayạ̣ | Mārīcir etc. De andere verwante teksten wijken hier af, verderop wordt hij echter soms wel genoemd, b.v. Vā. Pur. 2, 7, 28 (68, 28).

-3. Mầrìca: elders Mārīici. Is de volgende te identificeeren met Akṣaka, Vā. Pur. 68, 5? - Is saǹ Bahu verbasterd uit Svarbhānu, zeer vaak (b.v. Vị̣nu Pur. 1, 21, 5) vóór Vṛ̣aparvā (zóó, dus nom. -an)?; over wien boven, p. 424.

-4. Keçi : Keçin, een dānava, die in den vorm van een paard door Kṛnna gedood werd; zie b.v. Viṣnu Pur. 5, adhy. 16 (Wilson-Hail, IV, pp. 339 vlgg.). Op te merken valt, dat de bovengenoemde puranische parallelplaatsen dezen naam niet geven, wel echter het Mbh. 1,2530 .

-5. Madhurā of Mathurā, aan de Yamunā, geregeerd door Kaṃsa, den vijand van den jongen Kṛsna.

-6. Hayagrīzua, ook Hariv. 203; Vā. Pur. 68, 10; Bhāg. Pur. 6, 6, 29. Prāgjyotiṣa, vgl. Viṣnu Pur. 5, 29, 19 hatvā Murum Hayagrivaṃ... | Prāgjyotișapuraṇ... samupāgataḷ (n.1. Hariḥ). P. was een stad (en volk), waar de daemon Naraka huisde (Noord-Bengalen).

-8. Naraka of Bhauma (zoon van Bhūmi) was een vijand der goden, gedood door Viṣnu, welbekend uit het Bhomakāwya.

-11. Cambara, ook in 'n aantal andere teksten genoemd.

-12. Pradyumna was een zoon van Kṛnna en Rukmin̄i ; hij werd als zeer jong kind door Çambara geroofd en in zee geworpen; een visch verslond hem, doch deze visch werd gevangen en in Çambara's huis opengesneden; Ç's vrouw ziet het schoone knaapje en houdt het in leven. Later doodt P. Cambara. Zie Viṣnu Pur. 5, a. 27; WilsonHall, V, pp. 73 vlgg.

-13. Aniruddha, zie b.v. Hariv. 6715 . 
-14. Çarabha ; vgì. b.v. Bmọ. Pur. 2, 6, 12; Vā. Pur. 68, 12 Çarabhah Çalabhaç caiva Sūryācandramasāv ubhau. De tweede naam schijnt in onzen tekst op te treden als Bala.

-15. Wiz'asziān, zie boven, p. 415.

Twișimān, Skt. tviṣimant, energiek; glinsterend, schijnend; prachtig, enz. Hier merkwaardig gebruikt, mij niet van elders bekend.

p. 3ru-12. șaḑwarga: de șaḍwarga zijn de zes innerlijke vijanden van den mensch; ze worden niet steeds eender opgegeven. Een citaat in P. W. VII, 439 geeft: kāmaḥ krơhas tathā lobho harṣo māno manas tathā. - Vgl. ook b.v. Bhāg. Pur. 11, 18, 40: asaṃyatașạ̣vargah. - Zie voorts O.-J. Rām. 13, 52: kāmādi ṣ.; Tantu Pangg., p. 87.

-32. Anāyușāa, vgl. Bmḍ. Pur. 2, 6, 30 ; Vā. Pur. 68, 30 (de andere tekst-groepen niet); ook daar 5; Arūru Vā., Araru Bmḍ. B. en Vṛtra in Bmụ., Vãyu: B. en Janma; Wirakṣa als Vā.; de laatste naam afwijkend: Vṛṣa Bmọ., Viṣa Vā.

p. 3/1-3. Dhundhu, genoemde teksten aansluitend: Ara( $\bar{u})$ ros tanayah krūro Dhundhur...| nihatah Kuvalaçvena. Dh. leefde in een zee van zand en hinderde den wijze Uttankka in z'n overpeinzingen. Kuvalāçva doodde hem, waardoor hij zich den naam Dhundhumāra verwierf (zie b.v. Wilson-Hall, Vishṇu Pur. III, 264; zie b.v. Hariv. 671 vlgg.). - In Bmọ.-Vā. volgen thans twee zoons van Bala: Kumbhila (Vā.) of Nikumbha (Bmḍ.) en Cakravarman, dan twee van Virakṣa: Kālaka en Khara (Bmḍ.) of Vara. In onzen tekst contaminatie en verknoeid of werkelijke varianten? De vijfde zoon (de volgorde is dezelfde!) heeft daar 4 z.oons: Çrāddhahan (Vā.; Çrāddhāda Bmḍ.), Yajñahan, Brahmahan en Paçuhan (ç $>g$ is een zeer veelvuldige fout). - Kalokara: ? - Van V r tra, de laatst genoemde: jajñire çvasanād ghorād Vṛtrasyendreṇa yudhyatạ̣ | Bakā nāma samākhyātā rākṣaşāh ... | çatam tāni sahasrāṇi etc. (coll. Vā.-Bmụ. vs. 34 sq.; 35 sq.). - Samudaya: ?

-10. Citraratha enz.; Vā. 68, 37 heeft $\operatorname{Prab}(v) \bar{a}$ hy ajanayat putrān yajñe vai gãyanottamān $|\ldots|$ (39) ity eva devagandharvā(ḥ), daartusschen andere namen dan hier. Bmḍ. Pur. 2, 6, 38 heet de moeder Krodhā. - Citraratha is de koning der Gandharva's, Nārada een hunner. Tilottamā is een apsaras. Vgl. Vā. Pur. 69, 5 enz.

-11. Nārada, vgl. b.v. Vā. Pur. 69, 3; Mbh. 1, 2552; men zie b.v. ook Wilson-Hall, Vi. Pur. II, p. 285. Hij is een devagandharva, een gandharvarāja. 
-25. Ariștā bracht volgens Brahma Pur. 3, 105; Viṣnu Pur. 1, 21, 25 e.a. de gandharva's, volgens Matsya Pur. 6, 45 de kinnara's en gandharva's voort. Hāhā, Huhu, Suruci zijn gandharva's (Wilson-Hall, Vi. Pur. II, 285 vlgg.). Zie voorts Vā. Pur. 69, 46 Hạ̣so jyeșthah kaniștho 'nyo madhyamau ca Hahā Huhuh, voorts Dhiṣaṇa, Vāsiruci e.a.; Bmụ. I'ur. 2, 7, 10; 11, waar o.a. Vasuruci en (12) Suruci.

-28. Winatā, A. en G. in 'n aantal teksten, b.v. Brahma Pur. 3, 95; niet in Bmḍ.-Vā. De bekende geschiedenis van de geboorte van Garuda, het rijdier van Viṣṇu, den vijand der slangen, half-mensch en half-vogel, vindt men b.v. Mbh. 1, a. 16 vlgg.

p. 372-3. anah in, vgl. het glossarium; zeer moeilijke passage. Men verwacht: citta juga... Winatā n panah sarika. dharmapatnī, etc., of iets dergelijks. Ik heb een anakolouth aangenomen, mèt de lezing van $\mathrm{y}$. Een afschrift van een zich op Bali bevindend handschrift, mij welwillend verschaft door Dr. R. Goris, dat ik èn omdat ik het na de vaststelling van den tekst ontving èn omdat het korter is en nogal afwijkt van de andere hss., niet heb gebruikt, heeft hier: citta juga ya nimittanya. saì Winatā. makadharmapatn̄i. strī bhagawān Kaçyapa. - In het volgende levert r. 7 kahana enz. een moeilijkheid. Men zou ook kunnen denken aan: dadi ka anahamkāra, het geschiedde dan dat ze zonder a. was, zoodat ze dus zonder a. was. Sanskrit ahạ̣kāra is als phil. term in de Sāṃkhya-philosophie het principe, ,,,,vermöge dessen wir uns für handelnd und leidend usw. halten, während wir selbst, d.h. unsere Seele, davon ewig frei bleiben" (Jacobi). Die Funktion des A. ist also die Hervorbringung von Wahnvorstellungen, und zwar derjenigen Wahnvorstellungen, welche die Idee des Ich in rein materielle Dinge und Prozesse hineintragen", ", (Garbe, Die Säṇkhya-Phil.², p. 311). Zie voorts de aant. bij Bmọ. Pur., p. 258. De O.-Jav. vertaling is panaku, derhalve = subjectiveeringsorgaan. Voorts is ahamkāra: groote dunk van zich zelf, hoogmoed. Hier zou men dan dadi ka anahạ̣kāra (vgl. Skt. nirahaṇkāra) kunnen denken (overeenkomstig op r. 12 en 13): het geschiedde dus dat ze zonder trots was, zoodat ze dan zonder hoogmoed was. Vreemd is dan nihan panaku ri sira, tenzij dit: ,zoo was haar zelfbewustzijn", kan beteekenen en men de hoedanigheid uit het verband mag opmaken (over ka: Bijdr. dl. 88, p. 475). Het bovengenoemde afschrift heeft de passage aldus: alilaṅ... Winatā, praṇata matwan bhakti rin swāmi. an̉hin hana pamatĕk nin hankara ri san Winatā. dadi kahadañ-adan. ikañ buddhi-tattwa kapanguh de sañ Winatā. matannya n pakanak Garụ̣a. pamatĕk nin hankkara ri 
sañ Winatā. kadi hyan kadi triyak sañ Garuḍa. an̉hin hana lěwih kaçaktin ri san Garuḍa. lěwih sanke çaktin in hyan san Garuḍa. pamatěk ikañ pungun ri sañ Winatā. si tan pakapūrwaka samyajñāna. hetunya n kadi triyak san் Garuḍa wěkasan. apan si pungun. ya mārga nin matěmahan paçu.

-18. Kadrū, moeder der nāga's volgens verscheidene teksten; vgl. b.v. Viṣnu Pur. 1, 21, 19 vlgg. (Wilson-Hall, II, p. 74). Kapila volgens Wilson, t.a.p., n. 1 ook in het Vā. Pur. De naam van den 5en nāga: Karkoțaka, Viṣnu Pur. 1, 21, 21 e.a.

p. 373-3. yogī̧wara, vgl. ook Kats, S. h. Kam., pp. 145, vlgg.

-4. Khaçā: uitvoerig Bmḍ. Pur. 2, 7, 37 sqq.; Vā. Pur. 69, 71 sqq. Zie ook Br. Pur. 3, 105 Khasā (sic) tu yakṣarakṣāmsi; vgl. ook Wilson-Hall, Vi. Pur. II, p. 75. Over de namen van de zoons b.v. Vā. Pur. 69, 97 vlg. Yakșa en Rakṣa. De Yātu's of Yātudhāna's zijn een soort booze geesten, die als spookachtige gedaanten of als dieren verschijnen; ook wordt er van hen gezegd, dat ze vóór den zonnewagen gaan. Ze worden gelijkgesteld met de rākșasa's; rākṣasā(h) in Bmḍ. Pur. 2, 7, 90. Twaalf hunner vindt men volgens het Vāyu Pur. genoemd bij Wilson-Hall, Vishṇu Pur. II, pp. 291, 292. Ze gelden als afstammelingen van Kaçyapa en Surasā (ald., V, II, p. 252). Ze zijn kinderen van Jantudhanā in Bmọ. Pur. 2, 7, 85; 86; Vā. Pur. 69, 119 vlgg.

-7. Brahmadhanā vindt men vermeld Vā. Pur. 69, 118; Bmò. Pur. 2, 7, 84; ze heeft de Brahmadhāna's tot kinderen. - De namen van de Yātudhāna's (zie reeds boven, waar ten deele afwijkend) : Bmḍ. Pur. 2, 7, 89 vlg.; Vã. 69, 122 vlgg. Hcti en Praheti als Bmḍ. (Vā.: -tṛ i.p.v. -ti), Açru: Ugra (hieruit ontstaan, $g>c ̧$ vaak, zie b.v. O.-J. Bmḍ. Pur. p. 162, 6), dan Pauruṣeya ( $>$ p vaak, zie Wulff, Wir., p. 200), Vadha, Vidyut, Sphūrja (Bmḍ.) of (i.p.v. deze 2) Visphūrji (of -ja), daarna Vāta, Ayya (Bmḍ.) of Āpa (Vā.), die samen $>$ Wātāpa (Wātâpa) in onzen tekst; is Sḍaja < Sphūrja? Dan Wyāghra (yā $>$ e $>$ o ?), Sarpa (Vā.) of Sarya (Bmọ.).

-10. Bali; in het Bmḍ. Pur. schijnt na 2, 7, 89 een çloka te zijn uitgevallen. Het Vā. Pur. heeft 69, 124 Hetṛputras tathā Lañkur Lankor dvāv eva cātmajau | Mālyavāṃç ca Sumālī ca, derhalve afwijkend. In 't Bmḍ. Pur. vinden we een meer, in 't Vā. Pur. een minder volledige opgave van de kinderen van bovengenoemde Yàtudhāna's. Daarna gaan Bmḍ.- en Vā. en onze tekst verschillende wegen. 
-12. Kckasi: Kaikasī, een der vrouwen van Viçravas (zoon van Pulastya) en bij hem moeder van den bekenden Rävaṇa, Kumbhakarṇa, Çūrpaṇakhā en Vibhīṣaṇa. Over Viçravas' vrouwen en kinderen: Pargiter, Anc. Ind. hist. trad., p. 241 (men merke op, dat de familierelaties niet steeds gelijkluidend worden opgegeven; Kaikasī is soms de dochter van Mālin); Jahn, Saurapurāṇa, pp. 75 vlgg. (Saurap. 30, 14 vlgg.).

-14. Puspotkața (zóó Vālmīki), z'n eerste gemalin, had tot kinderen Mahodara, Prahasta, Mahāpārçva, Kumbhanakhī. Elders wordt echter ook een zoon Khara vermeld. Triçiras, elders T., Dușaṇa, Vidyujjihva; hun moeder heet Vākā. Kumbhanābha is in ander verband een bekende naam. Vidyujjihva, de echtgenoot van Çürpaṇakhā, wordt door Rāvaṇa gedood (Rām. 7, 23). Dundubhi (zoon) en Mandodarī, kinderen van Maya: Rām. 7, 12. Maya was de bouwmeester van de Asura's.

-22. Madhu en Kaițabha, twee daemonen, die door Viṣnu gedood werden. In den Harivaṇça b.v. wordt deze gebeurtenis verhaald, zie 11461 vlgg.; 11940 vlgg. e.a. Hun lichamen werden in zee geworpen en brachten een groote massa vet (medas) voort, tengevolge waarvan de aarde den naam medinī kreeg. Zie ook Mārk. Pur. 81, 49 vlgg. In het Rām. 7, 104, 6, worden de bergen van hun beenderen gemaakt. - Madhu is elders de zoon van Lola (Rām. 7, 61), weer elders is hij uit de duisternis geboren, terstond na het ontstaan van Brahmā, evenals deze dus pūrvaja; vgl. Hopkins, Epic Myth. p. 192. Lavana heerschte in Madhupura en Madhuvana (Hariv. 3061-3). Tijdens het bewind van Rāma doodde Çatrughna Lavaṇa (Rām. 7, 69), vernietigde Madhuvana en bouwde op de plaats daarvan Mathurā. Zie ook Wilson-Hall, Vi. P. III, p. 318. Madhurā = Mathurā. Tradities over Lavaṇa bij Pargiter, Anc. Ind. hist. trad., pp. 170 vlgg.

-26. Yakșa, de andere zoon van Khaçā, had een zoon Rajatanābha; uitvoerig Bmạ. Pur. 2, 7, 109 vlgg. (vgl. Vāyu Pur. 69, 138 vlgg.). - Bij het volgende: 2, 7, 119 Yakșo Rajatanābhaç ca guhyakānāṃ pitāmahạ̣. Guhyaka's zijn lagere godheden, onderdanig aan Kubera en zijn belast met het bewaken van schatten. Over Manizwarī : Bmọ. Pur. 2, 7, 119: Anuhrādasya daityasya bhadrāṃ Maṇivarām (sic) sutām | upayeme. Over de zoons: zie ook Oud-Jav. Bmḍ. Pur. p. 128, 4 vlg.; 151, 27. In het Skt. Bmḍ. Pur. vs. 220: Maṇivara en Manibhadra.

-28. tamolah. De woonplaats van de guhyaka's is volgens 't Mbh., 6. 
246 de Hemakūta. In het volgende citaat wordt echter gesproken van Alakā, de residentie van Kuvera en zijn volgelingen (Kirfel, Kosmographie, p. 59; Hopkins, Epic. Myth. p. 142-144). Hoogstwaarschijnlijk is die naam ook hier te lezen.

p. 37t-6. çîla nikain yakșa; over den aard van de yakșa's in de epen zie Hopkins, Epic. Myth., § 90 : ,the individual may be kindly, but as guardians with Rākșasas they can fight" etc. Ze worden ook punyajana genoemd, ,,goed volk”. Tan bari-bari; wsl. te verg. Tantu Pangg., p. 96, waar bari $^{2}=$ iemand, een of ander.

-17. De hss. lezen çakti, het afschrift mij verschaft door Dr. Goris çakta; zonder twijfel te lezen sakti resp. sakta, speciaal gebruikt voor het gehecht zijn aan deze wereld en hare genietingen.

-22. Mandara, een van de vier bergen in de richting van de hoofdwindstreken naast den Meru. De Mandara ligt ten O. van den Meru. Vgl. H. H. Juynboll, De mythe van den berg Mandara in de Javaansche letterkunde, Bijdr. Kon. Inst., 6, I, pp. 79-96. -- Het karnen van den Oceaan, het bekende verhaal; zie b.v. Viṣnu Pur., 1, a. 9; Wilson-Hall, p. 143 vlgg. De slang Çeșa (ook Vāsuki) heeft wel den naam Ananta, welke wordt verklaard als anantabhoga (zie Rām. $6,14,18)$. Ananta is ook wel eens onderscheiden van Çeșa; zie Hopkins, Epic. Myth. pp. 23 vlgg. Als eigennaam Anantabhoga ook in de Tantu Pangg., p. 76; vgl. ook Pigeaud, ald., p. 214. - Janārdana $=$ Vișnu. $-\mathrm{Na}$ de woorden makaya karma heeft het afschrift van Dr. Goris: ri sĕḍan nirâmutěr. In plaats van Anantabhoga leest het Bāsuki.

p. 375-1. ikin mānuṣa; meer genoemd hs. heeft hier een afwijkende passage, n.1.: ikin mānuṣa atyanta kakarṣaṇa hyun-hyun twasnya. rin mas mani. olihnya $\mathrm{n}$ anel adagan alayar. ri kapetan in mas mani. ri kasañsāran in çarīra. kunañ sañ ataki-taki bwat kawerāgyan. tan kasinitan pwa sira karakĕt rin sukawaya (1. sukhawāhya). apan taniya(?) humantasa. sakeń sańk(1.: s)ārārṇawa. kewalya kumĕlhumĕl awak nira rin kasantosan, etc.

deya, derya (zie crit. app.) zou kunnen staan voor Skt. dhairya, standvastig karakter, moed; wellicht beter van zin.

-7. kveva kāranaṇ, adv., vgl. kị̣ kāraṇam, wegens welke oorzaak, op welken grond?, b.v. Mbh. 1, 3600 C.

-10. umĕnin, het bovengenoemd hs. heeft umĕnĕ $\dot{n}$, ,de ș. zwijgen”, wat een beteren zin schijnt te geven; misschien kan echter aan O.-J. hĕnï de bet. van hĕnĕn worden toegekend, evenals Soend. hĕning $=$ stil zijn, stil leven, rust hebben kan beteekenen; vgl. Minangk. 
aniěng, I. helder, klaar; II. zuiver; III. stil, eenzaam. Men denke aan stilstaand water, dat rein is doordat de troebelmakende substanties bezinken; vgl. Mal. hĕning, doorschijnend-helder van water. In de tevredenheid en rust des gemoeds (kasantosan) ,.slaan” de șaḍwarga ,neer" en houden zich stil.

-12. antaḷkaraṇa. De Sāmkhya-philosophie leert, dat de organische wezens behalve het door de ouders verwekte, vergankelijke, grofmaterieele lichaam nog een fijn of innerlijk lichaam bezitten, dat met de ziel na den dood het grove lichaam verlaat. Dit innerlijke lichaam is de zetel en oorsprong van de psychische toestanden en functies. Het bestaat uit: buddhi, ahamkāra, manas, de tien indriya's en de vijf fijne elementen. Buddhi is het orgaan van het oordeel en besluit, ahaṇkāra ${ }^{1}$ ) : p. 428 , manas is mèt de uitwendige zintuigen (indriya's) ontsproten aan den ahamkāra en treedt als bemiddelaar op tusschen de indriya's en a. en b.; het expedieert de door de i. 's geboden objecten aan a. en b.; het is het orgaan van waarnemen, gevoelen, wenschen, enz. B., a. en $\mathrm{m}$. tezamen worden vaak als een eenheid samengevat, n.l. als het inwendige orgaan antahkarana. Volgens de Sāmkhya-phil. heeft dit de kwaliteiten vreugde, smart, begeerte enz. - In de Yoga-phil., zie bij P. Tuxen, Yoga, K $\phi$ benhavn, 1911, pp. 83, e.a. Zie ook P. Deussen, Alg. Gesch. d. Phil., I, 3, passim. Men vergelijke ook de publicatie van P. Jos. Abs, Sanātanadharma, 1923 (zie de aanteekeningen aldaar). Over Yoga-praktijk (rol van hypnose, suggestie, enz.) S. Lindquist, Die Methoden des Yoga, Diss. Upsala, 1932.

-19. samyagjūāna, wat bedoeld zal zijn met het overgeleverde, is juist, volledig inzicht (vgl. ook Sang h. Kam. a 55). Inzicht is de eisch die de Indische philosophisch-religieuze systemen stellen om de verlossing van de kwellingen van het aardsche bestaan te erlangen, al gaan ze in bijzonderheden wel eens uiteen. Het inzicht van de volkomen identiteit van ziel met Brahman eischt het Vedāntasysteem, kennis van het absolute verschil tusschen de materieele wereld en de oermaterie, waaruit ze ontstaan is, aan den eenen kant en de ziel aan den anderen de Sāṃkhya-philosophie, enz.

-20. dhyāna, enz. De yoga-praktijk kent acht bestanddeelen, „leden”,

1) Vgl. Saura Pur. 13, 6 vlgg. ,ik ben arm” of ,ik ben rijk”, ,ik ben een held", ,ik ben zwak", „ik ben dwaas”, ,ik heb groote kennis”, „ik ben mooi”, ,ik ben leelijk", ,ik ben een gever”, ,ik ben gierig”, — ,ik ben niet van adel”, , ik ben van adel", - ,'t mijne is ieder ding hiervan”, deze en dergelijke woorden en in 't algemeen iets dat den ahaṃkāra betreft. 
yogānga, n.1.: yama (zelfbedwang), niyama (verplichting tot observanties, reinigingen enz.), āsana (het innemen van verschillende lichaamshoudingen, wijzen van zitten), prānāyāma (regeling van de ademhaling), pratyāhāra (het aftrekken van de zintuigen van hun objecten), dhārañā (Sammlung; het beperken van het denken tot één plaats, b.v. top van den neus, navel, enz.), dhyāna (contemplatie), samādhi (contemplatie over slechts één object, Versenkung). Vgl. Tuxen, Yoga, p. 142; Garbe, Sāmkhya und Yoga (Grundriss), pp. 43 vlgg. Ook bij R. Schmidt, Fakire und Fakirtum... is veel hierover te vinden. Bijzonderheden in Patañjali's Yogasūtra, ed. Rājendralāla Mitra, Bibl. Ind., Calcutta, 1883, passim. Onze tekst heeft niet alle acht, doch wel een andere, tarka, wat wel een naam is voor de vijf laatstgenoemde yogānga's (reflexie, speculatie); zie Tuxen, pp. 142 vlgg.; vgl. ook Jahn, Saurapur., p. 100, n. 1.

-21. rajendriya; zooals boven reeds is opgemerkt, zijn de tien ,uitwendige zintuigen" (indriya's) mèt manas, het ,inwendige zintuig" uit den ahamkāra ontsproten. Tezamen vormen ze de elf zintuigen. De tien indriya's (vermogens) zijn van den manas afhankelijk, bepalen echter ook de werkzaamheid daarvan. Er zijn twee groepen te onderscheiden, de ,waarnemingszintuigen" (buddhīndriya) en de „daadzintuigen” (karmendriya), n.l. gezicht, gehoor, reuk, smaak, gevoel en spreken, grijpen, gaan, ontlasting hebben, nakroost voortbrengen; ze zijn te onderscheiden van de materieele organen, waarin ze gevestigd worden gedacht: het gezichtsvermogen in het oog, enz. Bij het ontstaan van de waarnemingszintuigen uit den ahaṃkāra heeft van de drie guna's sattva, bij dat van de karmendriya rajas domineerend invloed gehad. Ik herinner er aan, dat de theorie van de drie guṇa’s (,bestanddeelen”), die voor de Sāmkhya-philosophie bijzonder karakteristiek is (vgl. Garbe, o.c., pp. 272 vlgg.) leert, dat al het materieele bestaat uit drie onderscheiden stoffen, die een verschillende werkzaamheid hebben, een invloed uitoefenen, en in verschillende en aan verandering onderhevige wijzen in de materieele dingen aanwezig zijn: ze kunnen elkaar onderdrukken, ze kunnen zich paren enz. Al naar nu een dezer drie guna's (of twee hunner) ergens domineert, doet hij z'n aard en invloed min of meer zuiver blijken. De drie zijn sattva, zich uitend, wanneer het domineert, als „Licht und Leichtheit" in de wereld der objecten, als deugd, zelfbeheersching, gemoedsrust, geluk, tevredenheid enz. bij de subjecten; rajas, zich uitend als kracht en beweging bij de objecten; als smart, angst, zorg, ontevredenheid, jaloezie, haat, toorn, begeerte, hartstocht, D1. 92. 
snoodheid enz. bij de subjecten; tamas, dat zich uit als zwaarheid, starheid, duisternis in de wereld der objecten, als vrees, versaagdheid, vertwijfeling, onwetendheid, waanzin, traagheid, onreinheid, enz. bij de subjecten. Men kan dus raja(s)-indriya opvatten als die indriya's bij het tot stand komen waarvan rajas domineerde. De uitdrukking ken ik niet van elders. Het is echter een bekende voorstelling dat degeen die yoga verricht gehinderd, geremd wordt door de werking der drie guna's. Men zie b.v. Saura-Pur., a. 13, begin, waar (çl. 8) geleerd wordt: alles wat betrekking heeft op den ahamkāra bevat rajas, en ook, dat al het rajas bevattende den mensch kwelt. Men moet nu de indriya's terugtrekken, het manas er van los maken en in rust brengen. Elders vinden we de opvatting dat de indriya's, zonder beperking, tejas-achtig zijn; vgl. b.v. Vișnu Pur. 1, 2, 43 taijasānindriyāny āhur; zie ook b.v. Saura Pur. 21, 9; de indriya's zijn rajas-, d.i. tejas-houdend. - Onze tekst vergelijkt „,manah” met een olifant, Manu 2, 88 vergelijkt de indriya's met paarden: indriyāṇāṃ vicaratām viṣayeșv apahāriṣu | saṃyame yatnam ātișțhed vidvān yanteva vājinām. - Deze passage is geciteerd bij Van der Tuuk, K. B. W., IV, 755.

-22. antahhrdaya: deze term is mij niet van elders bekend.

-24. hïrabajra, adamanten hardheid vaker, b.v. Patañjali, Y. S. 3, 46. p. 376-10. yogiçuara, heer der yogins, meester onder de yogins, een b.v. in (le Sang h. Kam. veel gebezigde term.

papasah, smart enz. spruit voort uit de verbinding van ziel en materie. Men streve daarom naar volledige isoleering van deze beide. Deze isoleering heet kaivalya; Garbe, o.c., p. 386; Tuxen, o.c., p. 202 vlgg.; Deussen, Alg. Gesch. d. Phil. I, 3, pp. 541 e.a.; Farquhar, An outline of the rel. lit. of India, p. 131. Samādhi, de middelen daartoe, de magische vermogens, de isoleering van de verloste ziel zijn de vier hoofdstukken van de yoga-praktijk.

Hierop volgt een interessante beschrijving van de bovennatuurlijke vermogens die men door yoga verkrijgt, en wel zooals bij de yogapraktijk gebruikelijk, in trappen en gradatie. Hoe meer van deze vermogens, siddhi's, de yogin bereikt, hoe verder hij is voortgeschreden op den weg der perfectie. Eigenlijk doel van zijn streven zijn ze niet; ze zijn het resultaat van z'n meditaties en Versenkung, ze wijzen aan hoever zijn succes daarbij reeds is gegaan; ze verhoogen de macht van de ware kennis en zijn van belang om de isolatie van de ziel, wat hetgene is waarnaar men streve, te voltooien. Men verg. b.v. Tuxen, Yoga, pp. 178 vlgg. (Deensch); Rājendralāla 
Mitra, Patañjali Yogasūtra, Preface, pp. XXXIX, vlgg. Het Yogasysteem kent acht bovennatuurlijke vermogens, vibhūti, mahāsiddhi, aiçvarya (zie b.v. Vyāsa en Bhoja op Yogasūtra 3, 45; Tuxen, p. 183 vlg.; Mitra, pp. 157 vlgg.; Garbe, Sämkhya und Yoga, p. 46); n.1. animan, het vermogen zich uitermate klein, zoo klein als 'n atoom, onzichtbaar te maken; laghiman, het vermogen zich uitermate licht te maken, tūlapindavallaghutvaprāptih, ,zoo licht als een katoenballetje"; mahiman, de macht zich een ontzaglijke grootte te geven, añgulyagreṇa candrādisparçanaçakti, het vermogen de maan en dergelijke met den vingertop aan te raken (Bhoja, op Y. S. 3, 45); elders (Vyāsa) wordt dit vermogen prāpti genoemd (zie Tuxen, o.c., p. 183 , n. 405); prākāmya, vervulling van alle wenschen; bhūmāv unmajjati nimajjati yathodake, voegt Vyāsa er aan toe; vaçitva, heerschappij over de elementen en de natuur; içitrtva, macht over ontstaan, vernietiging en verdeeling (teșām prabhavāpyayavyūhānām iște, Vyāsa; bij Bhoja : çarīrāntaḥkaraṇeçvaratvam içitvam); yatrakāmāvasāyitva, het vermogen om naar wensch over de elementen te heerschen, welken toestand van elementen, grondstoffen, grondvormen, de yogin wenscht, dien nemen ze aan; anders bij Mitra, p. 121 „,kāmāvasāyitā, self-control, or the power of suppressing all carnal longings”, ,die Fähigkeit... sich durch den blossen Willen überallhin zu versetzen" (Garbe, Sāṃkhya und Yoga, p. 46). Er zijn bovendien nog andere vermogens te verwerven: kennis van verleden en toekomst, kennis van vroegere existenties, onderdrukken van hongeren dorst-gevoel, het betreden van een ander lichaam door de ziel, alwetendheid, enz. Ook lichaamskracht, schoonheid, en dergelijke kan de yogin verwerven; hij kan zich immuun maken tegen de vernietigende kracht van vuur, water enz. Bij enkele bijzonderheden noteer ik parallellen.

-14. dūradarçana: vgl. b.v. Mitra, o.c., Preface, p. XXXIX.

-16. jarā $w y \bar{a} d h i$, over het genezen van ziekten enz. door yoga, vgl Walter, Svātmārāma's Haṭhayogapradīpikā, Diss. München, 1893, p. XXIII.

-20. umansil, het afschrift van Dr. Goris heeft: umanisila.

-22. kadi kapuk, vgl. Bhoja bij Pat. Y. S., 3, 45 (zie boven). Zie Tuxen, o.c. p. 193: de Yogi verwerft een lichtheid, die hem in staat stelt over water te gaan, daarna over 'n spinweb, vervolgens over zonnestralen en ten slotte naar goeddunken in de ruimte te reizen. Vgl. ook Mitra, o.c., p. XL: ,he can travel with the quickness of the mind through air or through water, and go wheresoever he 
lists". Zie Lindquist, p. 179. [Thans ook Nawaruci, p. 51 P.]. -23. ahanta, genoemd af́schrift: gaganacara. nahan ta kalinanya. anhin $\tan$ wĕnan் aměn-aměnen swarga. rin bh ${ }^{\circ}$ etc. - Wandelen op het water, vgl. Kats, Sang hy. Kam., p. 176, n. 1.

-30. asțabhaga, dit schijnt hier te staan voor de acht bovengenoemde siddhi's, mahāsiddhi's, aiçvarya's. Bhaga staat meer voor aiçvarya; zie P. W. V, 170.

p. 377-3. ikan mänușa etc., passage, geciteerd in K. B. W., IV, 517. Over trikāya, enz., vgl. hetzelfde artikel in K. B. W., IV, 518.

-5. trikāya paramārtha. Over de trits kāyika, vācika, mānasika zie een andere noot, p. 403. In de Oud-Jav. literatuur ontmoeten we de uitdrukking trikāya vaker; vgl. b.v. Sang h. Kam. b 29, waar kāya, wāk en citta worden verklaard en daarna trikāya gelijkgesteld wordt met deze drie. Van belang is een citaat uit het Wratiçāsana (Juynboll, Cat., p. 202 vlgg.) in K. B. W., IV, 518: trikāya (volgt verklaring) ..., ika ta katiga pinasanakĕn manutana ṅ dharmakārya de saì paṇitita, kapwâdine makabhūmy açubhakarma, ..., ika ta pwa tha (?, kapwata Van der Tuuk) siniddhikara maprawrttya rahayu makabhūmi dharmasādhana, ya kāyika, wācika, mānasika nia ${ }^{\circ}$, ri kapagĕh nika katiga, yeka sinanguhan trikāya paramārtha nia ${ }^{\circ}$, lin saì paṇ̣̂ta, ndyânun ta karih de san sādhaka rumĕgěpa sań hyan trikãya. - Onze hss. lezen (ook het hs. van Dr. Goris) : trikaya; opgevat als trika ya paramārtha, trias die de hoogste waarheid is?

-10. bhäruana, reflexie, bepeinzing, contemplatie, het zich voor den geest brengen, voorstelling; het voor den geest brengen van een god en de reflexie over hem. Vgl. ook Sang h. Kam. a 40 en vlgg., a 62. Mijn lezing sah in deze passage is een gissing, zonder pretentie. Men vergelijke de door Kats, Sang hy. K., p. 139 geciteerde passage, die door onze plaats beïnvloed schijnt.

așta-dewatï, er zal hier niet moeten worden vergeleken met een plaats als Smarad. 39, 7 çrī Kāmeçwara padmaguhya makaçakti $\dot{n}$ așta-dewì datěn, waar van acht çakti's sprake is, zoo meermalen voorkomend; men zie b.v. Schrader, Pāñcarātra, p. 55. Met de acht godheden zullen worden bedoeld de Lokapāla's, de wereldhoeders, die in de vier hoofd- en de vier tusschenliggende windstreken gelocaliseerd gedacht worden. Als groep van 8 zijn ze na-episch. Ze bestaan uit de hoogste godheden, behalve Brahmā, Çiva, Viṣnu; de opgaven loopen nog al eens uiteen, de toewijzing van een vaste plaats aan ieder is later dan de opsomming der namen. Indra in 't Oosten, Yama in 't Z., Varuna in 't W., Kubera in 't N., Soma in 't N. O., 
Agni in het Z. O., Sürya in het Z. W., Vāyu in het N. W. is wel de meest bekende voorstelling. Ze worden ook bij Manu, 5, 96 (zonder hun standplaatsen) opgesomd; van belang voor onze plaats is echter een voorschrift als Manu 8, 23 dharmāsanam adhișthāya...। pranamya Lokapālebhyah kāryadarçanam ārabhet. - Men vergelijke voorts H. Meinhard, Beiträge zur Kenntnis des Çivaismus u.s.w., Diss. Bonn, 1928, pp. 23 vlgg.; Goris, Bijdr. pp. 126 vlg. Zie ook Bmḍ. Pur. p. 88, 1. - Achttallen van goden komen meer voor, vgl. b.v. de 8 Bhairava's e.a. (Wilson, Essays, II, p. 33).

-19. Krodhavą̧ā. Men vgl. Bmḍ. Pur. 2, 7, 170 vlgg.; Vā. Pur., 69, 198 vlgg. Atah çrnuta bhadram vah prajāh krodhavaçānvayāḥ | 170 | Krodhāyāḥ kanyakā jajñe dvādaçaivātmasạ̣bhavāḥ | tā bhāryā Pulahasyāsan, etc. De citaten in onzen tekst wijken ook hier volkomen af. Onze tekst geeft 10 dochters. De eerste in Bmọ.-Vā. Mrgī, 2e gelijk, 3e en 4e Haribhadrā en Irāvatī, dan $\mathrm{Bh}^{\circ}, \mathrm{K}^{\circ}$, maar Daṃṣțaā, daarna Ṛṣā (Bmọ.) of Niçā (Vā.), Tiryā, Çvetā, Saramā, Surasā (Bmụ.) of $\mathrm{Çv}^{\circ}$, Svarā, Surasā (Vā.). Dus zeer gering verschil, afgezien van het andere aantal.

-25. Pulaha als de verwekker van bhūta's, piçāca's, wilde dieren enz. ook Mbh. I, 2572 Pulahasya mṛāḥ sị̣hā vyāghrāḥ kimpuruṣās tathā, e.a.; vgl. Pargiter, Anc. Ind. hist. trad., p. 186, ook p. 243.

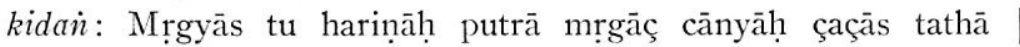
nyankkavah çarabhā ye ca ruravah prșatāç ca ye (Vā. 69, 200; zie ook Bmọ. 2, 7, 173 vlg.).

-27. Mrganandāa : mrgarājā (Vā., d.w.z. leeuwen of tijgers; ṛkṣāçva, Bmḍ.) Mrgamandāyā gavayāçvāpare tathā | mahiṣoșțravarāhāç ca khaụgagauramukhās tathā; gavaya of mahiṣa: sapi; u.: ușțra; kh.: warak; gauramrga of gaura is de bos gaurus, een soort buffel, wsl. de kubwa (: kĕbo, zie ook K. B. W., II, 370) ; zie Vā. Pur. 201; Bmḍ. 174 vlg.

-30. Harī: vervolg: Hares (Vā., Haryās Bmọ.) tu harayah putrā golāngūlatarakșavaḥ ! vānarāh kinnarāç caiva vyāghrāḥ (Vā., māyuh Bmọ.) kimpuruṣās tathā; dus paarden, de gol.-apen (=,eine Affenart mit einem Kuhschwanze und schwarzem Gesichte", Pet. Wdb.), hyaena's, apen, kinnara's, tijgers (of māyu's, de blater, bruller, loeier, 'n zeker dier; soms als appositie bij kimpuruṣa). In den Jav. tekst slechts aapsoorten en de açwawadana's; deze naam duicit soms, als Açwamukha's, een volk aan (vgl. O.-J. Bmḍ. Pur. 151, 20); dan wonen ze ten N. van den Himālaya, vgl. Matsya Pur. 120, 58; Mārk. Pur. 58, 43; soms ook worden er Kimnnara's of dergelijke 
wezens onder verstaan. In het Bmḍ. Pur. volgen nog vele dieren. p. 378-1. Madhyakata, mij verder niet bekend.

-3. Irāwatī, thans, maar uitvoeriger, in het Vā. Pur. $(69,203)$; hier in afwijking met de boven gegeven volgorde. Het Skt. Bmḍ. Pur. anders. Hier wordt nu gesproken over den vorst der olifanten, Indra's rijdier Airāvata, die volgens het gewone verhaal bij het karnen der Oceaan als eerste olifant te voorschijn is gekomen. De naam luidt meestal Airāvata, doch ook wel Airāvaṇa. Het Vã. Pur. spreekt $(69,205)$ van Airāvata, wat men afleidt van irāvant, irā, drank, lafenis, verkwikking.

-7. Çwetā; in het Vāyu Pur. volgt thans een uitvoeriger, van die welke onze tekst geeft afwijkende, beschrijving (vs. 206 vlgg.). Diggajăh (in 't tweede lid ook andere woorden voor „olifant”) zijn er 4, later 8; ze helpen de aarde dragen en beschermen de hemelstreek; de namen verschillen. Vā. Pur. 69, 207 geeft: Añjana, Supratìka, Vāmana, Padma; P. hier als Kumuda. Voor variaties zie Kirfel, Kosmographie, p. 122. Zie ook Hopkins, Epic Mythology, p. 17: „,the late grouping of the eight is not recognised in either epic, but for convenience may be given here: East, Airāvata; S. E., Puṇuarīka; S., Vāmana; S. W., Kumuda ; W., Añjana; N. W., Puṣpadanta; N., Sārvabhauma". Men zie voorts Berg, Aant. bij Kidung Sunda, pp. 143-145 (B. K. I., 1927, dl. 83).

-10. nāga kūrma; de schilápad, die bij vele volkeren in de kosmogonie een rol speelt, draagt, zooals we uit de beschrijving van het karnen van den oceaan weten, den berg Mandara op z'n rug. Vgl. b.v. Mbh. $1,16,10$ vlgg. Sukth. (=1, 1122 vlgg.), waar o.a. : ūcuç ca kūrmarājānam... surāsurāḥ | girer adhișthānam asya bhavān bhavitum arhati. Later wordt deze schildpad met Viṣnu zelf gelijkgesteld, zie b.v. Viṣṇu Pur. 1, 9, 87 : bhagavān kūrmarūpī svayạ̣ Harị̣. Hiernaast vinden we de voorstelling, dat Viṣnu als schildpad de geheele aarde op z’n rug draagt : zie b.v. Jayadeva, Gìtagov. 1, 2, 2: kṣitir ... tava tișthati prșthe ... Keçava dhṛtakacchaparūpa ... Hare. - Hier is sprake van een nāga (wel zóó te lezen). Kūrma als naam van een ,slangenkoning" vinden we Mbh. 1, 59, $40 \mathrm{~S}$. (= 1, 2549); ook is er wel sprake van 'n asura in de gedaante van 'n schildpad, b.v. Mbh. 3, 84, 121. Merkwaardig is in onzen tekst ook het voorafgaande Hari. - Het meergenoende afschrift heeft: nāga. kūrma. dhumāraṇa pṛthiwī.

-13. Kapiçā ; het kroost van Kapiçā wordt omstandig besproken: Vā. Pur. 69, 251 vlgg.; Bmọ. Pur. 2, 7, 374 vlgg. Onder haar nageslacht 
bevinden zich (Vā. vs. 253) chagalah chagalī caiva, enz. Chagala beteekent bok, $-\bar{\imath}$, geit. Deze woorden zullen in bhagala, $-\bar{\imath}$ van onzen tekst steken (verwisseling van $c$ en $b h$ ook Bmḍ. Pur. p. 148, 30); de vormen bhangala, $-\bar{\imath}$ (K. B. W., s.v.), zijn dan secundaire verdere verbasteringen.

-14. kubhānda; in een merkwaardige passage in het O.-J. Ādip., p. 29, ond., wordt geleerd: san Mrgī makanak piçāca, gaṇa bhūta kumbhāṇụa pūtana; het Sanskrit Mbh. mist de geheele passage (vgl. vs. 1072 vlgg. C.). Zie ook O.-J. Rām. 23, 6 bhūta kubhāṇ̣̣a pūtana. Pūtanā staat in het Skt. ook wel voor rākșasī. Kațapūtana wordt genoemd door Manu 12, 71: amedhyakuṇapāçi ca kṣatriyah kaṭapūtanah, een kṣatriya (die van z'n dharma is afgevallen) wordt een $\mathrm{kat}^{\circ}$, die vuiligheid en lijken eet. De commentatoren hebben ook kațha- en kūṭa-. Kullūka verklaart: kațap $^{\circ}$ : pretaviçeșah. - Kumbhāṇ̣̂a's zijn, bij de Boeddhisten, een groep van daemonische wezens (,wier scrotum potvormig is"). In Bmḍ. Pur. 2, 7, 384; Vā. Pur. 69, 259 is sprake van kựmāṇda, 'n synoniem, naar het schijnt. In de Vā. en Bmọ. Pur. volgt thans een zeer uitgebreide passage. -16. simha, vyāghra, vgl. b.v. Vā. Pur. 69, 283.

Surasā, vgl. Vā. Pur. 69, 315 Surasā 'tha vijajñe tu çatam ekam sarpānām etc.; Bmọ. Pur. 2, 7, 443.

-22. Tãmrāa vgl. Bmụ. Pur. 2, 7, 445; Vā. Pur. 69, 316, waar zes dochters worden vermeld, evenals elders. De vijf namen zijn zonder eenige afwijking van de lezing van het Vā. Pur. (vgl. ook Kirfel, P. P., p. 208, 3 noot). Het zijn vogelmoeders, Çyenī is b.v. de oermoeder van de groote roofvogels, adelaars, haviken, enz. Dhṛtarāșțī, ook Hamsapatnī, van de watervogels (dhārtarāșțra is een soort gans, volgens de lexica wit, met zwarte pooten en snavel). Uitgebreider beneden.

-26. Aruṇa; (Bmọ. 2, 7, 446) ; Vā. 69, 326: Aruṇasya bhāryā Çyenī.... Sampātị̣ ca Jaṭayum ca prasūtā pakṣisattamau. Aruṇa, Vinatā's zoon en broeder van Garuḍa (b.v. Hariv. 224; Gar. Pur. 6, 58; Brahma Pur. 3, 95; Matsya Pur. 6, 34 e.a.), is de wagenmenner van den Zonnegod, de personificatie van het morgenrood (aruna := ros-rood; de kleur van het morgenrood). Deze passage elders anders, zie Wilson-Hall, Vishṇu Pur. II, p. 73. Over Aruna en z'n rol bij 't vernietigen der slangen zie J. Charpentier, Die Suparnasage, pp. 302 vlgg. Vișadhara = giftige slang.

-29. Jațāyu, vgl. Rām. 3, s. 49 vlgg.

p. 379-1. Jamaloka, zooals ook in 't Skt. (vgl. b.v. Kirfel, Kosmogr., p. 143) 
wel voorkomt naast Janarloka, een der hoogere hemelen. Vgl. ook O.-J. Bmạ. Pur., p. 110, 24 vlgg. De opwekking tot een deugdzaam leven ontbreekt op de par.-plaats in Vā.- en Bmḍ. Pur.

-8. pramāda, het afschrift van Dr. Goris heeft hierna: dușțabuddhi. amṛta ri san buddhi sādhudharma, yatna; yatna naranya bhakti etc. in dat afschrift.

-10. kapanguhan, vgl. Sang hyang Kamah. p. 34: marapwan kita tan angel mangabhyāsa ri kapangguhan i kahyangbuddhān; p. 45: kapangguhan bharāla.

-15. Satyaloka, de hoogste hemel; vgl. Bmḍ. Pur., p. 280. - De hier volgende reeks van wedergeboorten ken ik zóó niet van elders. Dergelijke reeksen worden echter veel vaker vermeld; vgl. b.v. Mbh. 13, 111, 43 vlgg., waar 'n zondaar achtereenvolgens wordt wedergeboren als ezel, os, rākșasa, brahmaan of als worm, ezel, zwijn, haan, jakhals, hond, mensch enz.

-19. sādhana, vermoedelijk: pinaka-; vgl. Bmḍ. Pur., p. 55, 27, Aant. p. 380-1. kanya ya enz.; deze passage luidt in het afschrift van Dr. Goris als volgt: kadyanga nin asu sulakșana, somya. tan darpa. kinasihan. wwata janmanya $n$ matra. kunañ yan ya dadi asu. wirūpa. darpa. kudisĕn. asin wwañ melik iriya. mañjanma ta ya dadi kayu-kayu. wwat in panisinan. pinakatulumpakan san Dṛdḍasyu muwah. Men ziet: bekort, en bij moeilijkheden eenvoudiger, stukken overslaand.

-22. man்utsarga tattwajñāna. sinit twasnya amirěsěp. samañkana rakwa hwata janmanya; zóó Goris' afschrift. Manuyak(a?) is mij niet bekend.

-30. Sampāti, Bmọ. Pur. 2, 7, 447 heeft: Sampāter vijayāh putrā dvirāsyāh prasahāç ca ye, Vā. Pur. 69, 317 : Sampātir ajanat putram kanyām ekām tathaiva ca, Matsya Pur. 6, 35 e.a.: Sampātiputro Babhruç ca Sighragaç ca..., in Bmḍ. Pur. dus ook roofvogels.

Jaṭāyu's kinderen: kākagṛdhrāçvakarnininạ (Vā. Pur., t.a.p.), kañkagṛdhrāç ca karṇikāh (Bmḍ. 448); Matsya Pur. 6, 36 geeft: Jaṭāyuṣah karṇikāraḥ çatagāmī ca viçrutau | sāraso rajjuvālaç ca bheruṇ̣aç cāpi tatsutāḥ; zoo ook Padma Pur. (zie Kirfel, P. P., $217,36)$.

p. 381-4. Bhāsī, Krauñcī, Çukī (,,papegaai”) en Dhṛtarāștrīi zijn in Vā.en Bmọ. Pur. (resp. vs. 318; vs. 448) de vier vrouwen van den Garuḍa; Çukī ook Linga Pur. 63, 29; Matsya Pur. 6, 30 e.a.; zie ook boven. De volgorde waarin de kinderen van deze vier meegedeeld worden is in Bmd..- en Vã. Pur. Çukī, Bh., K., Dh. Het kroost van Bh. is daar (Bmḍ. 2, 7, 455; Vā. 69, 326) : bhāsā ulū- 
kāḥ kākakukkuṭāh | mayūrāh kalavinikāç ca kapotā lāvatittirāh, d.i. bhāsa's (soort roofvogels), uilen, kraaien, hanen, pauwen, musschen, duiven, kwartels en patrijzen; in eenige punten overeenstemmend met onzen tekst; het valt op dat de andere pur. teksten slechts òf bhāsa's (,kites”, „koningswauwen”, Wilson-Hall, Vishṇu Pur. II, p. 73) òf kurara's (,zee-adelaars") vermelden.

-7. Kroñcī; kinderen van Krauñcī in Vā. Pur. (327) vārdhīṇasān, „,neushoorn" (vgl. P. W. VI, 950); in Bmḍ. Pur. (vs. 456): vādhrinnāsāḥ çyenāh kurarāh sārasā bakāh etc., ,neushoorns, valken (e.d.), zeeadelaars, ardeae sibiricae, ardeae niveae", volgens het door Wilson (t.a.p.) geciteerde Vãyu Pur.: „K., the parent of curlews, herons, cranes". Elders anders.

-9. Dhrtarāṣtrī tu haṃāmç ca kalahamıāmçç ca bhāminī| cakravākāmçç ca vihagān sarvāṃç caivaudakān dvijān (Bmọ. 457, vg̣1. Vā. 328); vgl. Wilson's opgave over het Vāyu Pur. „Dh., the mother of geese, ducks, teal, and other water-fowl". Elders anders, zelfs Dh.'s naam.

-11. Çukī, hier geheel afwijkend van Bmọ. en Vā., die veel uitvoeriger zijn. Merkwaardig is echter, dat juist hier andere teksten (niet alle) dicht bij ons geschrift staan: b.v. Linga Pur. 63, 30, Matsya Pur. 6, 31 Çukī çukān ulūkāṃ̧ç ca janayām āsa dharmatah (dus: ,papegaaien en uilen”), vgl. ook Viṣnu Pur. 1, 21, 15 çukī çukān ajanayad ulūkī pratyulūkakān, e.a. Het vermoeden ligt voor de hand, dat de Vãyu- en Bmọ.-teksten, die trouwens een onderling verschil in namen hebben, hier een jongere omwerking of uitbreiding ondergaan hebben.

-17. Irā, vele teksten hebben slechts dit of ongeveer dit: Irā vṛkșalatāvallīs tṛ̣ajātīç ca sarvaçạ̣ sc. janayām āsa (Vi. Pur. 1, 21, 24; Kirfel, P. P. 170, 107), „I. bracht voort boomen, kruipplanten, slingerplanten en allerlei grassoorten”. Uitgebreider zijn Bmḍ.- en Vā. Pur., resp. vs. 459 vlgg.; 330 vlgg., die echter in details uiteengaan. Bmọ. heeft als namen Latā, Alatā, Vīrudhā, Vā. L., Vallī, V . Men kan in het Ag. p. lezen Nalā (van nala, riet) of Nālā (van nāla, holle stengel, vrl. lotusstengel).

Vergelijking van de drie teksten is interessant: Bmọ.: Latā vanaspatĩñ jajñe Puspād api phalāvahān; Vā.: L. v. j. hy apuṣpān pulinasthitān. Dan: Bmọ.: puṣpaiḥ phalagrahair vṛkșān Alatā samasūyata | gulmās tathā latāvallyas tvaksārās tṛnajātayah Vịrudhas tad apatyam hi; Vā.: yuktān puṣpaphalair vṛkṣ̂aṃ Latā vai saṃprasūyate | atha Vallī tu gulmāṃç ca tvakṣāāàs tṛ̣ajātayaḥ | Vìrudhā tadapatyāni. 
Een vanaspati is in de indeeling der Hindoes een boom, die vruchten draagt zonder in het oog vallende bloesems; een vṛkṣa een boom met zichtbare bloesems en vruchten; twaksāra eigenlijk riet, bies.

-28. odwad, vgl. N. Jav. odod, uithangen (in de lengte).

p.382-8. sambuin niin ibu: dergelijke leeringen zijn vaker aan te treffen; men zie b.v. Mbh. 12, 307, 5 vlgg. (=11332), waar asthisnāyuç ca majjā ca, beenderen, pezen en merg van den vader, tvanimāmsaçoṇitañ ceti, huid, vleesch en bloed van de moeder komen. Elders andere opsommingen. Rām. 2, 35, 28 sluit zelfs den invloed van den vader op de karaktervorming uit. Vgl. voorts J. Jolly, Medizin (Grundriss), p. 55: von der Mutter stammen Blut, Fleisch, Fett, Mark, Nabel, Herz, Leber, Milz, Nieren, Blase, Mastdarm, Bauch, After, Eingeweide, Lunge, Netzhaut, überhaupt die weichen Körperteile. Vom Vater stammen Haare und Bart, Nägel, Zähne, Knochen, Adern, Sehnen, Gefässe und Samen, überhaupt die harten Körperteile. Over embryologie in het algemeen de geheele $\S 41$, pp. 53 vlgg. Zie ook: Windisch, Buddha's Geburt u.s.w. (Abh. Phil.hist. K1. d. kön. sächs. Ges. d. Wiss. XXVI, 2; 1908), pp. 86 vlgg. en daar genoemde literatuur. Op Java: Goris, Bijdrage, p. 107, beenderen, spieren, enz., merg is het aandeel van den vader, vleesch, bloed, huid van de moeder. - I.p.v. r. 8 heeft Goris' afschrift: apan ikan çarīra sakin ibu, ikañ urip sakin bapa.

-11. Agama, vgl. de Inleiding, p. 354.

-12. auruh mara, bovengenoemd afschrift: wruh mawâwaknya, humrĕt manah sari-sari.

-15. pinrih, het afschrift van Dr. Goris : pinrih nira kāladeça, kinon ira ta mahaběti ikañ manah. - I.p.v. hinila (r. 17) : hayu.

-21. prthagjana, ook de natuurlijke mensch, die onder den invloed van de onwetendheid, begeerte enz. staat.

-27. Bhrgu. Het hier nu volgende geslacht is dat van Bhrgu; men verg. ook O.-J. Bmḍ. Pur. p. 79, 18 vlgg. en de Aant., p. 259. - Over dit geslacht: Bmọ. Pur. 2, 1, 73-100; Vā. Pur. 65, 72-96. Er bestaan van de daar gegeven voorstelling afwijkende opgaven, b.v. Matsya Pur. 195, 11-45. In het kort vindt men een overzicht bij Pargiter, Anc. Ind. hist. trad., p. 193. De tweede vrouw van Bhrgu heet gewoonlijk Paulomī en is de dochter van Puloman (b.v. Vā. Pur. 65 , 73). Het Matsya Pur. maakt Divyā een dochter van Puloman (195, 11). Over Çukra enz. Aant. op O.-J. Bmḍ. Pur., p. 259. Zie ook boven, p. 424.

p. 383-5. caturupāya: d.i. sāma, dāna, bheda en daṇ̣̂. Aardig is wat Goris' 
afschrift geeft: san wruh rin caturupaya kamandaka. - Zie ook Pargiter, pp. 194, 195, als guru, ācārya der daitya's.

-8. V rșaparvan, koning der daitya's, dānava's, asura's, de vader van de bovengenoemde Çarmișțā (vgl. pp. 424 vlg.).

-10. Çukra's kinderen, Pargiter, p. 196. Somapānapitr is m.i. ontstaan uit Somapānām $\mathrm{p}^{\circ}$. De Somapa's zijn 'n klasse van pitaras, vgl. b.v. Mārk. Pur. 96, 42; Manu 3, 198. Het Bmụ. Pur. 1, 1, 77 heeft: piț̣̣nāṃ mānasī kanyā somapānāṃ yaçasvinī | Çukrasya bhāryā Gaur nāma vijajñe caturah sutān. Nagna in genoemde teksten niet. Er zijn echter ook elders, b.v. Mbh. I, 2545, af wijkingen. Jayantī en Devaya $\bar{n} \overline{\text {, }}$, in overeenstemming met b.v. Bmọ. Pur. 2, 1, 86.

-15. Pulomī: bij haar (Paulomī) verwekte Bhṛu Cyavana. Toen zij zwanger van hem was, begeerde de daemon Puloman (hier Duloma, zie boven, p. 368, 31), haar, bij afwezigheid van Bhrgu tot echtgenoote en wilde haar meevoeren. Het kind in de moederschoot hoorde haar jammerklachten en kwam te voorschijn agnirūpa, het deed den aanrander verschroeien. Vgl. Mbh. I, 875 vlgg.; in 't Jav. Ādip. pp. $18 \mathrm{vlg}$.

-18. Sukanya à enz., in vele andere bronnen, vgl. Pargiter, p. 194, n. 8 Çaryāti was een zoon van Manu Vaivasvata. Hun kinderen zijn Apnavāna (zóó oorspronkelijk; later Āpnuvāna, Vā. 65, 90: Ātmavāna; Bmụ. 1, 1, 93: Āpravāna) en Dadhīca. „Dadhīca is hopelessly enveloped in fable" (Pargiter, p. 197). Vgl. Bmḍ. vs. 94: Sārasvatah (ook elders, b.v. Mbh. 9, 2931 vlgg.). Sarasvatyāṃ Dadhīcasyodapadyata. Widyātmika, niet in Bmọ. en Vā. op de geciteerde plaats; met v. d. Tuuk, K. B. W., s.v., -ātmaka te lezen?

-21. Recī; Bmọ. vervolgt: Ṛcī patnī... Apravānasya Nāhuṣī | tasyām Aurva ṛsir jajñe, etc. In 't Vā. Pur. (vs. 92) en elders Urva; zie Pargiter, p. 197.

-25. Wadawānala zal te lezen zijn, een uitdrukking, die ook in het Sanskrit enkele malen voor vaḍavāgni, het hellevuur ergens in de Lavaṇănnava, voorkomt. Ook Vaḍavāmukha; vgl. mijn Aant. bij O.-J. Bmd. Pur., p. 153, 5, op p. 329.

-28. ūror: ūrum (Bmḍ.; ūrū Vā.) bhittvā in de genoemde Voor-Ind. teksten. Rcīka dus gelijkgesteld met Aurva. Volgens de gewone lezing (Pargiter, p. 198) is Ṛcīka Aurva's zoon; Rcīka huwt met Satyavatī, de dochter van Gādhi, den koning van Kānyakubja (zie ook Viṣnu Pur., bij Wilson-Hall, IV, p. 16). De vergissing in onzen tekst is waarschijnlijk ontstaan doordat Rcika ook Aurva genoemd 
wordi, Aurva's vrouw niet genoemd wordt en z'n moeder Raci heet. Vgl. Pargiter, o.c., pp. 68, 198.

-30. Jamadagni, de oudste van R 's zoons; bijzonderheden: Pargiter, pp. 198 sq.

p. 384-1. Janārdana $=$ Viṣnu-Kṛ̣ṇa. Hier dezelfde avatāra.

-3. Hchaya: de Haihaya's e.a. ,belonged to the great family of the descendants of Yadu who occupied the countries of the river Chambal (d.i. de Carmanvatī, de grootste zijrivier van de Yamunā) in the north and the river Narbada in the south; but it is difficult to identify with precision the kingdoms indicated by these different names. Haihaya is often used almost as a synonym of Yãdava to denote the whole group of peoples" (Rapson, in The Cambridge History of India, I, p. 316). Zie ook de uitvoerige noot van Pargiter, ad Mārk. Pur. 58, 34 (p. 371).

-4. Arjuna Kārtavīrya (vgl. mijn O.-J. Bmọ. Pur., p. 314), de duizendarmige, had oneenigheid met Jamadagni, die door A.'s zoons gedood werd, waarop Rāma A. doodde en geweldig tegen de Haihaya's woedde.

-8. pinunyakčn, in het crit. app. is dit aan te vullen.

Kaçyapa; nadat hij de kṣatriya's verdelgd had, hield hij een offer en gaf de aarde aan Kaçyapa, Pargiter, p. 200 (waar referenties). Over 'n viçvajit-offer zie boven, p. 412. Over dit offer b.v. Brahma Pur. 213, 218 vlgg., waar o.a.: Māricāya dadau prītah Kaçyapāya vasumụharām || vāraṇāṇı turagãñ çubhrān rathāṃç ca rathināṃ varah | hiranyam akṣayạ̣ dhenūr gajendrāṃç ca mahīpatị ||

-12. Rāma. Ook hier is de tekst zooals de hss. dien geven niet duidelijk. Er wordt melding gemaakt van de in het Rām. 1, s. $74-76$ beschreven gebeurtenissen: nadat Rāma Sìtā, de prinses uit Videha, had gehuwd ontmoette hij op den terugweg Paraçu-Rāma, die hem uitdaagt zijn van Viṣnu afkomstigen boog te spannen. Rāma schiet den pijl af en vernietigt daarmee den hemel dien Paraçu-Rāma zich had verworven. Rāghazi'a = Rāma, Daçaratha's zoon. Het woord sarčngapa is vermoedelijk een verbastering van Skt. çāringa, boog, speciaal de boog van Viṣnu.

Het K. B. W. III, 107, vermeldt een , ک̧aranggapāça” als wapen van Krṣṇa; wellicht heeft dit ook hier gestaan. - Men vergelijke deze passage met het Oud-Jav. Rām., zang 2, einde, dat van Vālmīki afwijkt. Deze plaats behoeft niet te bewijzen, dat onze auteur het O.-Jav. Rām. niet gekend kan hebben, eerder heeft geschreven. Het afschrift van Dr. Goris heeft na yajña $(r, 11)$ : prihatịn pwa san 
Paraçu-Rāma. umantuk in swarga karika. mataninyan pinatra-kasihan ira. ilani<akĕna tě ?> kap çrī Rāma Dāçaratha etc.

-26. Tripurușa; wat in de Sanskrit letterkunde Trimūrti heet, de Drieeenheid van Brahmā, Viṣnu en Çiva. Elders (b.v. Bmḍ. Pur. p. 55, 6 en in de Tantu Pangg.) vinden we ook Trisamaya. Vgl. Goris, Bijdrage, pp. 56 vlg.

-29. tattwa, de leer der tattwa's, principia, grondelementen, is bij de verschillende richtingen niet steeds gelijk. De Sāṃkhya-philosophie stelde 25 principia op (pañcavimççatitattva), n.l. behalve de geestelijk gedachte ziel, 24 materieele, n.l. de Oermaterie, de drie innerlijke organen buddhi, ahaṇkāra, manas, de vijf waarnemings- en de vijf handelingszintuigen, de vijf tanmātra's (grondstoffen) en de vijf grove elementen. „Wenn als das höchste Ziel des Menschen das tattva-jñāna ,die Erkenntnis der Prinzipien” bezeichnet wird, so heisst das für den Inder zugleich ,die Erkenntnis der Wahrheit”; die beiden Bedeutungen von tattva fliessen hier vollständig zusammen". Bij andere richtingen anders, b.v. bij Schrader, Pāñcarātrā, p. 162, n. : ,the ten elements, ten senses, three-fold Inner Organ, Prakrti, Prasūti, Māyā, Kāla, Niyati, Çakti, the Puruṣa, Highest Heaven, and the Lord; but the next chapter explaining these admits that the ,highest principle", namely the Lord, is ,not a principle” or ,higher than a principle". Weer anders bij de Çaiva-Siddhānta, vgl. Schomerus, o.c., p. 444 , s.v. In de Bhuwanakoça wordt melding gemaakt van dwādaçatattwa (,tattwa rwa wĕlas”), vgl. Goris, Bijdrage, pp. 83 vlg.; n.l. Rudra, puruṣa, awyakta, buddhi, ahanikāra, pañcatanmātra, manah, ākāça, bāyu, agni, āpah, pṛthiwī; zie Goris, t.a.p. In onzen tekst weer afwijkend. I.p.v. sakein sor heeft Goris' afschrift : san keçwarya. I.p.v. anta heeft het: ,hantatatwa”.

p. 385-1. Brahmakșema, veilig en rustig verblijven bij B.

-3. muktapada, de mukta's, verlosten, zijn ook elders een groep „,hemelbewoners”, vgl. b.v. Schrader, o.c., pp. 57 vlgg.

-6. yoga di; thans volgen eenige andere namen (bij verschillende secten) van dezen muktapada, verkregen door voleindiging van inzicht in alle tattwa's. -De passage herinnert aan Sang h. Kam. b 44 vlgg.; vgl. Speyer, Z. D. M. G. 67 , p. 352 . De namen van de secten, die hier genoemd worden zijn met die uit andere gegevens verzameld en overzichtelijk gerangschikt door Goris, Bijdrage, pp. 101 vlgg. Achter yogitapakșa zet Goris :? Ook ik ken de benaming niet van elders; aan de beteekenis ,,dol”, die yogita in het Skt. heeft zal hier niet zijn te denken. Dr. Goris' afschrift heeft: yogipakșa. Paramanairātmya : 
vgl. Sang h. Kam. b 45: san hyan் adwaya mwan san hyan் adwayajñānâtah apan sira wĕkas nin winarahakĕn, ya ta matannya n san hyañ yogādi parama-nairātmya naran ira waneh de sañ Boddha; hier dus bij de Boeddhisten. Daar de volgende passage zeer vergaande overeenkomst met onze plaats vertoont kan men in yogitapakṣa een naam voor de Boeddhisten zien. Men zou zich kunnen afvragen, of de hier voorkomende naam verband houdt met de benaming van de Boeddhistische (Mahāyānistische) school der Yogācārya's; de broer van den grooten meester van deze richting, Asanga, Vasubandha, die volgens de overlevering te Nālandā gedoceerd heeft, had als volgeling o.a. den in de Sang h. Kam. (a, 40, vgl. Kats, pp. 9 vlg.) genoemden Dignāga. Zie b.v. Kern, Manual of Ind. Buddh. pp. 126 vlgg. Deze richting op Java: Krom, Hindoe-Jav. Gesch. ${ }^{2}$, pp. 118; $122 ; 152$.

-7. Bherazamārga; de Bhairawa's zijn een der Çivaïtische secten, die zich gronden op den çākta-āgama: ,5. Bhairava-Schule, die sich von der (als 4 genoemde) Vāma-Schule durch gewisse Riten und dadurch unterscheidet, dass sie an Stelle der Çakti Bhairava, eine Inkarnation Çivas, setzt” (Schomerus, o.c., p. 3). Over Bhairawa b.v. Wilson, Essays .... on the Religion of the Hindus, I, passim. Zie ook Goris, o.c., pp. 101 vlgg.; 127 vlgg.; Sang h. Kam., t.a.p.; Pigeaud, T. P., p. 356, s.v.; Krom, H. J. Gesch., p. 295 en elders (aldaar: Bhairawamārgānugamana). Anantap. als Sang h. Kam., b. 45.

yogādi- als Sang h. Kam., b. 45.

-8. Siddhānta, hier met toevoeging van Ç. en P. Zie Goris, t.a.p.; Krom, o.c., p. 400. Over de verschillende systemen, die tezamen den naam Çaiva-Siddhānta dragen: Schomerus, o.c. Deze richting neemt een derden band aan, waardoor de ziel gebonden is, n.l. het ānavamala, het grondkwaad, dat de ziel tot een atoom (anu) maakt (zie Schomerus, o.c., p. 42 en elders) in tegenstelling met die der Pāçupata's, die slechts twee boeien kennen, māyā en karma. Over de P.'s: Goris, o.c., pp. 101 vlgg.; 126.

niṣkala (zie Goris, o.c., vgl. p. 164) en parama in de Sang h. Kam., t.a.p., alwaar ook Weṣnawa; vgl. Goris, pp. 98; 101 vlgg.; zie ook Krom, o.c., p. 230.

paramaçūnya, vgl. Kats, S. h. K., p. 143.

-11. antapada, mij slechts van hier bekende term.

-14. aștabhaga, Goris' afschrift: așțaguna.

-18. sakala-niṣkala, vgl. Goris, o.c., p. 92, n.

walin etc., in Goris' afschrift: walin ta dadi tan wruha rin 
aditattwa (N. B.), dan de çloka, daarna: ikañ āditattwa, bh. B., W., $\bar{I}$., sira ta a. naran ira yāwat sira etc.

-24. yāroat sira; thans volgt een evolutie-keten van de meer naar de minder volmaakte stadia, die een ziel kan doormaken. Dat de ziel eerst in lichamen met weinig organen, planten en dieren komt, dan door verdienste enz. hooger stijgt, is een zeer verbreide opvatting. Vgl. b.v. Schomerus, o.c., pp. 264 vlgg.

p. 386-3. inuniweh yan pakasaji dharmakarana, bwat hyan, irika etc., afschrift van Dr. Goris.

-12. rimbit linnya, aldaar: rimbit rin anggĕlar maṇụalādi (of rina ang $^{\circ}$ ?). - $\mathrm{Bij}$ rimbit vgl. Arj. wiw. 22, 5 en de Mal. bet. „overladen met werk" en derg.

1.337-17. mungaha rin tamba mahoṣadhi heeft Goris' afschrift. Voor citrakāra: citrankkara. I.p.v. katham enz. (r. 20) : kapan (als y) siddha keșți rasika? Daarna sājñ̄ā etc.

-22. In deze passage sluit Goris' afschrift zich in hoofdzaak bij onzen tekst aan.

sājñ $\bar{a}$, over deze passage vergelijke men de Inleiding, p. 383 vlg.

p. 388-3. akrodha, enz., 'n gewone voorwaarde. Vgl. b.v. Manu 6, 92 dhrtih kṣamā damo 'steyạ̣ çaucam indriyanigrahah | dhīr vidyā satyam akrodho daçakạ̣ dharmalakșaṇam. Over yama (voorschriften tot zelfbedwang) en niyama (het houden der observanties) : Tuxen, Yoga, pp. 143 vlgg.; vgl. ook R. Schmidt, Fakire und Fakirtum, hfdst. VI, 1; 2. In Purāṇa's en derg. : b.v. Agni Pur. a. 371, waar het bedwingen der hartstochten en zinnelijke behoeften wordt besproken. - Vgl. ook op Java b.v. Sang h. Kam. a 12, a 32.

-14. rāga dweșa: twee der kleça's, plagen, smarten, anvechtingen, kwellingen, gebreken. Avidyā (niet-, verkeerd-weten), asmitā (,,egoïsme”), rāga (begeerte, hartstochtelijk verlangen), dveșa (afschuw, afkeer), abhiniveça (,Selbsterhaltungstrieb”) is het vijftal der Yoga-philosophie; vgl. Tuxen, o.c., pp. 112 vlg.; Garbe, Sāmkhya und Yoga, p. 43. Zij staan het ,weten” in den weg. Over kleça ook Sang h. Kam. a 18 , a 26 , b 40 , b 43 , b 48, a 49 . Vgl. Lindquist, p. 93.

-27. mankes : mankana $\mathrm{n}$ ulaha nin manuṣa tan etc., afschrift van Goris. p. 389-8. wiku, over den guru, vgl. de Inl., pp. 368 vlgg.

-9. saì gĕlěma, gĕlĕmanilwanii wișaya, afschrift van Goris.

-19. ${ }^{\circ}$ vadas: ${ }^{\circ}$ vadaç ceva, afschrift van Goris.

-22. inuniweh: over Āgama vgl. de Inleiding, p. 354 vlg.

-23. Wedānta, zooals bekend, meer genoemd in Purāṇa's en dergelijke teksten, b.v. Viṣnu Pur. 1, 22, 81; 5, 17, 16; met Vedānta is niet 
steeds het systeem bedoeld. Kennis van den Vedānta wordt b.v. aanbevolen door wetboeken (b.v. Manu, 6, 94; vgl. 2, 160), purāṇa's, Visnuiten (,the ideal teacher... must be well versed in Veda and Vedānta (Upaniṣads), Pāñcarātra, and other systems (tantra)", Schrader, Intr. to the Pãñc., p. 121), enz. Men zie ook Jahn's opmerkingen, Saurap., pp. XV, vlgg., Garbe, Bhagavatgītā, p. 21.

-24. soḍaçatatio'a, zie boven, p. 445. Over eenige dezer tattwa's, grondelementen, principes, vgl. Schomerus, Çaiva-Siddhānta, passim. In het daar beschreven systeem is b.v. Vidyā-tattva het tiende, het element, dat bemiddelt tusschen het vermogen dat eigen is aan de zielen en hun organen om in te zien; pradhāna is de materie in chaotischen toestand, de oer-materie; vgl. Garbe, Sāṃkhya-Phil., pp. 266 vlgg. Kālatattva, is no. 7 , de tijd, het element, dat de resultaten van het karman tot rijpheid brengt en ze toedeelt (ook Kalātattva komt als no. 9 in genoemd systeem voor, het element dat het eeuwige, de zielen bindende grond-kwaad, Ānava-mala, eenigszins krachteloos maakt en eenige kennis verschaft). Widyātattwa ook bij Goris, Bijdr., p. 25, alwaar ook A tmatattwa.

p. 390-6. madhyamaguru, over den guru een en ander in de Inleiding, pp. 368 vlgg. Evenzoo over de dỉkṣā.

-7. nirdvandva, onverschillig tegenover de tegendeelen, als leed en vreugde enz., vrij van jaloezie; onafhankelijk.

-10. panirea-rwa, cf. Sang hy. Kam., p. 154.

-11. aihiin etc., tan hana wiṣaya (gespeld wiçaya) ri sira, Goris' afschrift. Hierna: nirașa. tan hana tṛṣna nira. tan kĕnen sañçaya. nirmala çuddha malilan. wruh rin ekatwa. tasak ri san hyan Caturweda, mwan rin aḍyatmikatatwa (sic). dharmapararta kusala. san wiku etc. Belangrijk afwijkend!

p. 391-3. i huwus, huwus pwa dinikṣan de nira, afschrift van Goris.

p. 391-8. rajendriya, zie boven, p. $433 \mathrm{vlg}$.

-11. kleça, zie boven, p. 447.

-16. iṣt $i^{\circ}$, i.p.v. dit citaat aldaar: makaprayaçcitta nika.

-18. dīkșā hinanakĕn wěkasan tinut, interpungeert Goris' afschrift.

-19. siddhayogīçvara: siddhapandita, afschrift van Goris.

-20. wwai tan padīkșă, dergelijke bepalingen treffen we vaker aan. Vgl. b.v. Kulārṇava-Tantra, 14, 11 guruçiṣyāv ubhau mohād aparīkṣya parasparam | upadeçạ̣ dadad grhṇan prāpnuyātām piçācatām ; 14, 13 asaṃkrṛtopadesañ ca yah karoti sa pātakī | vinaçyati ca tanmantrạ saikate çālivījavat.

p. 392-2. sugati ${ }^{\circ}$, aldaar: kasugatin. 
-5. Aingiras' geslacht wordt behandeld door Pargiter, Anc. Ind. hist. trad., pp. 218 vlgg. Vgl. Bmc̣. Pur. 2, 1. 101-113; Và. Pur. 65, 97-108, Matsya Pur. 196. -- Surūpạa. S. Mārīcī. Svarāṭ Kārdamī en Pathyā Mānavī kanyā waren z'n drie echtgenooten.

-11. Wṛhaspati, Brhaspati. Over deze figuur Pargiter, o.c., pp. 186 vlg.; die betoogt, dat er 3 B.'s te onderscheiden zijn, de planeet, de guru der goden en de .,historische rși” B.; in de traditie worden ze echter herhaaldelijk verward. - In Bmọ. en Vā. staat, althans hier, niet wat onze tekst verder toevoegt over zijn kennis enz. - Ter illustratie van de familierelaties:

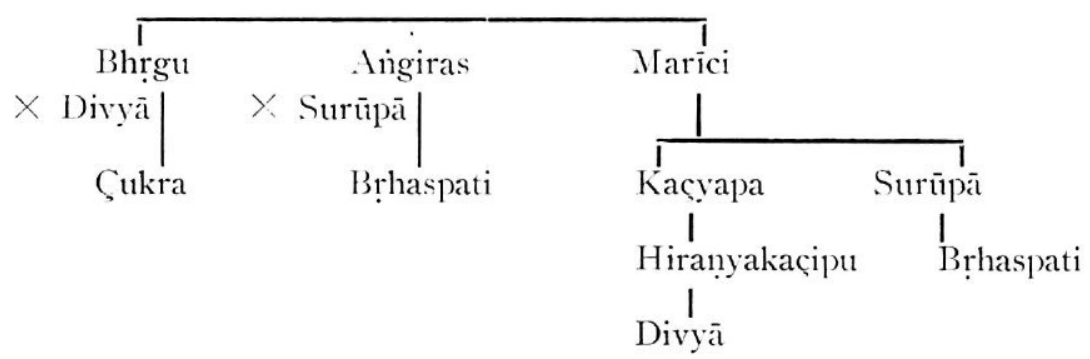

-23. (cija: Brhaspati had volgens een op vele plaatsen overgeleverde traditie, een oudere (zie ook O.-J. Ädip.. p. 103, 23) broeder, als Ucathya, Utathya, Uçija enz. bekend (Pargiter, pp. 157 vlg.) : Ucathya schijnt de correcte naam te zijn. Echter worden er vaak twee personen onder verstaan. Ucathya en Uçija (zoo b.v. Vā. Pur. 65, 100). Ucathya had een zoon Dirghatamas, die blind geboren was (of bijziende), later kreeg hij het gezichtsvermogen (of : dit verbeterde) en nam den naam Gotama of Gautama aan. Elders wordt hij echter zoon van Lçija genoemd, b.v. Bmḍ. 2, 1. 106, waar men. zooals Pargiter, o.c., p. 161, 1. 1, vermoedt: athausijo zal moeten lezen. - Over deze personen ook O.-J. Adip., pp. 103 vlg.

-26. Halyā; hier een afwijking van de Bmḍ.- en Vā. Pur. - De naam staat voor Ahalyā, de in de Sanskrit literatuur meermalen genoemde vrouw van Caradvant (zie beneden); soms wordt ze echter de vrouw van Gautama genoemd (als hier, vgl. b.v. Pet. Wdb., s.v.; Wilson-Hall, Vishṇı Pur. V. II, p. 4 e.a.), een verklaarbare verwarring. (laar Ç. als zoon van Gotama (die ook wel Gautama heette) den naam Gautama droeg. Tgl. ook Wilson-Hall. Vishṇu Pur. IV. p. 146. - Het verhaal van A.'s overspel: Rām. 1, 48.

Añjañ, elclers Añjanā, b.v. Rām. 4, 66, 8. Merkwaardigerwij̣s komt de vorm Anjānī in de Mal. Hikajat Rama (Shellabear) voor:

Di. 92. 
vgl. Zieseniss, Rāma-Sage, pp. 80 vlg. e.a.; de tekst van Roorda van Eysinga heeft Anjātī. ,.(Dewī) Anjātī ist aus Anjānī für Añjanā verschrieben", Zieseniss, p. 81, n. 2; Añjanī komt blijkens onzen tekst reeds vroeg voor. Vgl. K. B. W. I, 370; B. K. I., 54, 519.

p. 393-2. Kumbhakarṇa, broeder van Rāvaṇa.

-3. Çaradīàn, ,a paternal cousin of Dīrghatamas is called Çaradvant" (Pargiter, p. 221). Vgl. de par.-plaatsen Và. Pur. 65, 101 Çaradvāṃç cāpy Utathyajah. -- Volgens een in Harivamçça 1784 vlgg. en eenige andere teksten (vgl. ook Wilson-Hall, IV, p. 147 ; Pargiter, pp. 116, 222 vlgg.; Kirfel. P. P. p. 548) uiteengezette genealogie hadden Çaradvant en Ahalyā een zoon Çatānanda, die een zoon Satyadhrti, die als kinderen de tweelingen Kṛpa en Kṛpi, van wie gezegd wordt (Kirfel, I. I'. 548, 92 a) : ete Çāradvatāh proktā ete te Gautamāh smṛtāh. Hiervoor heeft het Matsya Pur. 50, 12: ete Çaradvatạ putrā ākhyātā(h). Uit een dergelijke lezing is de verkorte genealogie kunnen ontstaan, die men in onzen tekst en in enkele Sanskrit werken vindt (vgl. Pet. Wdb., s.v.; vgl. Bhāg. Pur. 9, 21, 34 vlgg.; Mbh. 1, 5072 vlgg.): Çaradvant vader van Kṛpa. Zoo ook Oud-Jav. Ádip. pp. 125 vlg.

-6. Bharad đōja, zoon van Mamatā (de moeder van Dīrghatamas, zie boven), en Brhaspati, Pargiter, p. 158.

-7. Kanza ; er zijn verschillende Kanwa's; hier is bedoeld de bekende ṛ̣i, die Çakuntalā, de dochter van Viçvāmitra en Menakā, in het woud vond en opvoedde. Vgl. Pargiter, o.c., p. 227 : „A Kanva is mentioned in Dusyanta's time..., but this Kanva is expressly called a Käçyapa...., and so could not be a member of the Kānvas, who were Angirasas”. Over de familie van „Kanva”, Pargiter, o.c. pp. 225 vlgg., Hopkins. Epic Myth. pp. 138; 177.

Droṇa, zoon van Bharadvāja (Pargiter, o.c., p. 218), leeraar in de krijgskunde van Kaurava's en Pāṇ̦ava's.

-10. sodaçabyüha, over de opstelling van 'n leger of $z$ 'n onderdeelen, de troepen in opstelling: Kāmandlaki Nítisāra, hfdst. 19; vgl. ook Kautilya, in Meyer's vertaling, p. 578 + noot 2; alwaar tien vormen van slagorde.

-13. Çakuntalā, grootgebracht door Kanva, huwde met Duṣyanta en werd moeder van Bharata, den voorvader der Bhārata's (zie ook O.-J. Ädip., p. 89).

-14. Kuntī en Vasudeva waren kinderen van Çüra (vgl. Pargiter, o.c., p. 107 en elders), van de Yādlava-familie. Kuntī werd moeder van de drie oudste Pāṇ̣ava’s, Vasudeva vader van Kṛ̣na. Kuntī had 
een adoptief-vader. Kuntibhoja, een neef van haar vader. In een citaat uit het Cantakaparwa, bij Van der Tuuk, K. B. W., III, 220 a wordt Kuntiboja gelijkgesteld met ..Dursanta” (Dusyanta) : ,.mangka binikṣèka... ingaran mahārādja kuntibodja sang dursanta, ..... sang kuntibhodja maputra titiga, kakung kalih istri tunggal... ngaran sang bhasudèwa...", merkwaardig vergeleken met wat onze tekst hier geeft.

-25. Pulastyo; deze çloka vertoont merkwaardige afwijkingen in de eigennamen, die blijkens het metrum grootendeels vanaf den beginne aanwezig moeten zijn geweest. Is de çloka misschien op Java gemaakt?

Viçraz'a is gelezen naar $\mathrm{y}$ (behalve de eerste maal, waar $\mathrm{y}=\mathrm{x}$ ).

39+-1. Ilā ; gewoonlijk heet zij Ilavilā of Iḍaviḍā, ook Ilivilā (zie WilsonHall, Vishṇı Pur. V, II, p. 69). Elders ook Ilā? Zij was de dochter van koning Tṛnabindu, huwde met $P$. en had tot kind Viçravas Ailavila. Zie Pargiter, p. 241; Jahn, Saurap., p. 75. Devavarṇinī, dochter van Brhaspati, was een van de vrouwen van Viçravas (zie Pargiter, t.a.p.), Kubera Vaiçravaṇa z'n zoon. Deze K. V. had vier zoons Nalakübara (in onzen tekst vermeld). Rāvaṇa, de bekende vijand van Rāma, Kumbhakarṇa. Vibhịșạ̣a en 'n dochter Çürpaṇakhā (zie boven, p. 430). Aldus de voorstelling bij Pargiter, waarvan echter afwijkingen voorkomen; zie b.v. Jahn, t.a.p. en p. 76; Jacobi, Das Rāmāyaṇa, p. 189, n. (Rāvaṇa, Kumbhakarṇa, Çūrpaṇakhā en Vibhīṣaṇa geen zoons, doch halfbroeders en -zuster van K. V.). Ook volgens het Mbh. en het Hariv. (zie de in P. W. IV, 66 geciteerde plaatsen) is echter Nalakūbara een zoon van Kubera. Over deze genealogie ook Stutterheim. Rāma-Legenden u.s.w. in Indonesien, Text, pp. 23, e.a.

Truacuindu wordt in de Sanskrit literatuur meermalen genoemd als koning, vader of grootvader van Viçāla, den stichter van Vaiçāli (vgl. b.v. Pargiter, Anc. Ind. hist. trad., p. 273), en ook als muni (vgl. b.v. Mbh. 3, $15575=3,263,5 ; 9,3433=9,61,45$; Saura Pur. 3, 19; 4, 2, z'n kluizenarij ligt aan de Revā = Narmadā). Op Java komt hij meermalen voor, in literatuur en kunst (vgl. Bosch, T. B. G. 57, 434 vlgg.; Pigeaud, T. P., pp. 285 vlg. e.a.; Poerbatjaraka, Agastya, pp. 41: 55. 92 vlgg.; Krom, Inl. H.-J. Kunst, Reg., s.v.). Bosch bespreekt, t.a.p. een bekend beeld van hem, dat hem op het ruggestuk in 'n inscriptie maharși noemt: in onzen tekst is hij onder de saptarṣi, de .,zeven" groote zieners, als 
sterrebeeld de Groote Beer, opgenomen. In de T. Pangg., p. 128 geeft Agastya hem z'n waardigheid over.

-3. Haridewa; deze persoon wordt hier in verband genoemd met de Diëng; onwillekeurig is men geneigd hem te identificeeren met Haricandana, die op de Diëng vereerd werd (vgl. Krom, H.-J. Gesch.², pp. 183, 193 e.a. en daar genoemde literatuur; ook Kern, V. G. VI, 294; 295, n. 1: Bosch. T. B. G. 57, p. 439; id., Oudh. Verslag 1923; Pigeaud, T. P., pp. 272 vlgg.; Poerbatjaraka, Agastya, pp. 65 vlgg.: 74 vlgg.: Bosch, T. B. G. 67, 479 vlgg.) Men vgl. Pigeaud, p. 272, ond.

-4. Anaka, wie is dit?

Märkandeya, in de T. P., p. 89 (als Karmandeya) als dewaguru op den Kailāsa genoemd: zie pp. 126 vlg. (naam correct), waar Agasti z'n opvolger is. Vgl. Pigeaud, pp. 242; 244 vlg.; 286 vlg. Over Damalun, id., p. 244, en elders.

-10. Reddhi, Kubera's vrouw heet ook Yakṣī, Yakṣiṇi, of ook Cārvì (zie P. W., s.s. v.v.). Hier als in Mbh. 13, 6750. Ṛddhir Vaiçravaṇasya ca, e.a.

-15. Atri: over de Ātreya's Pargiter. Anc. Ind. hist. trad., pp. 228 vlgg. Datta of Dattātreya: Atri had bij zijn vrouw Anasūyā drie zoons (anders b.v. in het Oud-Jav. Bmḍ. Pur., p. 61, 22; zie de aant.), Soma, Dattātreya en Durvāsas, die incarnaties waren van deelen van Brahma, Viṣṇu en Çiva, zie Mārk. Pur., adhy. 17.

-17. Vasiṣtha en Arundhatī, Pargiter, p. 204. Zie Vāyu Pur. 70, 83 vlgg. ; Bmọ. Pur. 2, 8, 91 vlgg.; Linga Pur. 1, 63, 81 vlgg. Hun zoon heet Çaktri (Và. Pur.) of Çakti (Bmḍ. Pur.). Bij het volgende Vā. vs. 83 e.a. .... janayac Chaktrer Adṛçyantĩ Parāçaram (zie ook Pargiter, p. 208). Parāçara en Satyavatī ouders van Vyāsa. - Vā. Pur. vs. 84 vlg. Dvaipāyanād Araṇyāṃ vai Çuko jajñe guṇānvitạ̣ utpadyante ca Pĩvaryāụ șạ̣ ime Çukasūnavah | Bhūriçravāh etc. ( 5 zoons en 1 dochter; anders dan onze tekst). Çuka komt b.v. in het Bhāg. Pur. voor: aan hem deelde z'n vader dit Purāna mee; deze verhaalde het aan Parikșit, enz. - Cipari < Wipari < Pīwarī.

-23. Aștadaçaparcia, vgl. O.-J. Ádip. p. 2. Merkwaardig is ikin (Goris' afschrift heeft $i k a \dot{n})$; deze hier aanwezige?, deze hier goed bekende?, deze waartoe ons werk behoort? Zie de Inleiding, p. 386.

-24. pañcagati: vgl. Tantu Pangg.. p. 83 pañcagati sangsara; K. B. W. IV, 290.

p. 395-1. Itihāsapurāna: vgl. O.-J. Bmụ. Pur. p. 82, 14-25.

Dharmaçāstra, de over de godsclienstige plichten, zeden. gebruiken 
en ,recht" handelende literatuur. Vyāsa wordt als auteur van een dharmaçāstra vermeld: Winternitz, Gesch. der ind. Lit., III, p. 500.

-6. Samjiñā was de echtgenoote van Vivasvant, den Zonnegod (Āditya, Sūrya enz.). Vgl. b.v. Mārk. Pur., adhy. 77. Zij geldt als de dochter van Tvastṛ. Zooals we boven zagen, p. 443, had Çukra bij Go 4 zoons; een hiervan was Tvastṛ, die twee zoons had, Triçiras-Viçvarūpa en Viçvakarman. (Pargiter, p. 196).

-7. Pāta; zeer merkwaardlige vermelding van dezen naam. Pāta wordt wel opgegeven als een naam van Rāhu; men zie Pet. Wdb. IV, 641; schijnt echter zeer zelden als zoodanig voor te komen. Rāhu is de daemon die de maan ..grijpt" en daardoor maansverduisteringen teweeg brengt; ook is hij de maaneclips. Bij Varāhamihira Brhats. 3, 6, wordt Tvaștar, als godheid, daemon van een eclips genoemd. Hier is Pāta = Tvaștar. Het verhaal van de geboorte van Vaivasvant en Yama, b.v. Mārk. Pur. t.a.p. Vaivasvata is de Manu onder wiens patriarchaat we thans leven; zie ook het Oud-Jav. Bmọ. Pur., Reg. v. eigennamen, s.v.

-9. Yama: deze geldt wel degelijk als de heer over het doodenrijk; vgl. b.v. Mārk. Pur. 77. 4. Ook in het Oud-Jav. Bmḍ. Pur. is sprake van deze Vaivasvato Yamah, vgl. p. 170, 11.

-11. tan สưnain; vgl. b.v. Viṣnu Pur. 3, 2, 2 vlgg., waar het verhaal eveneens wordt meegedeeld ; vs. 3 asahantī tu sā bhartus tejaç Chāyāṇ yuyoja vai | bhartuḷ çuçrūṣaṇe 'raṇyạ̣ svayạ̣ ca tapase yayau.

-14. Sãzuarna, wordt in het Viṣnu Pur., vs. 4 niet genoemd (daar 3 kinderen: Çanaiçcara = Saturnus, een ,.andere Manu” en Tapatī). Het blijkt echter uit andere plaatsen, vgl. b.v. Mārk. Pur. 80, 3 kathitas tava Sāvarṇiç Chāyāsạ̣jñāsutaç ca yaḥ ; Bhāg. Pur. 6, 6, 41 Chāyā Çanaiçcarạ̣ lebhe Sāvarṇị̣ ca Manụ̣ tatậ. Vgl. ook Bmọ. Pur. 3, 1, 51; Vã. Pur. 100, 55 ; doch daar vooral resp. 2, 59. 33 vlgg. en 84,32 vlgg.. waar dezelfde geschiedenis.

-16. Uttarakuru, zoo ook elders, vgl. Mārk. Pur. 77, 22; 78, 21 tato 'çvarīpadhṛg Bhānur Uttarān agamat Kurūn | daḍ̣çe tatra Saṃjñãñ ca vạ̣avārūpadhārinịm; Bmụ. Pur. 2, 59, 46; Vā. Pur. 84, 48. Over de Kuru's in het Noorden, b.v. O.-J. Bmọ. Pur. p. 135, 32 vlgg.

-19. Aşwinodewa, zoo ook elders, namen b.v. Bmọ. Pur. 2. 59, 76; Vāyu Pur. 84, 77. Nakula enz., eveneens in overeenstemming met de gangbare opvatting.

-21. Wezvaswata: Manı Vaivasvata had negen zonen (vgl. Bmḍ. Pur. 3, 60, 2-3; Vā. Pur. 85, 3-4 e.a.), en een dochter Ilā. De oudste zoon Ikṣvāku was de stamvader van de Aikṣvāku dynastie te 
Ayodhyā. ook bekend als het Zonne-geslacht; Ilā's afstammelingen, de Aila's vormden het Maan-geslacht. Zie b.v. Pargiter, Anc. Incl. hist. trad.. p. 84 .

-22. Dilipa en $I k s c ̧ a k u$, meermalen genoemd als vermaarde koningen; vgl. b.v. Mbh. 6, 314 vlgg. Ook Dilipa, Raghu, Aja waren koningen van Ayodhyā, vgl. Rām. 1. s. 70, waarover Pargiter, o.c., p. 92. Is Ikșiākukula (p. 396, 3) bedoeld? Zie beneden. Vgl. Tantri K. ed. Hooykaas, p. 62. Men zie ook Oud-Jav. Adlip., p. 89: san Suhotra makastrī san S., anak saì Ikṣwākukula; vgl. Mbh. I, 3719 (1, 89, 26) : Aiksvākī : een mogelijk uitgangspunt.

p. 396-2. reh, Goris' afschrift: ri de nira; i.p.v. kadyangan: kadi krama; als namen daar: D.. Ikṣwāku (!). R.. A.

-12. kunain: Goris' afschrift: kunani ulah san brāhmaṇa. manke ulah nira.

-14. pinakapurohita, purohita, huis-priester van een vorst, die de huisriten heeft te vervullen. Vele voorschriften voor den purohita, b.v. Viṣnụ, 3, 70: vedetihāsadharnaçāstrārthakuçalạ̣ kulīnam avyañgạ̣ tapasvinạ̣ purohitaṇ ca varayet: Yãjñ. 1, 312, eenigszins andere eischen: vgl. ook Gautama, 11, 12 vlgg.. waar de purohita moet zijn geleerd (in den Veda), van edele familie, welbespraakt, goed gevormd, van den juisten, niet te ouden leeftijd, van goeden aard, enz.; ook elders, b.v. Schrader, Intr. to the Pãñc., p. 132.

matrisandhya: de drie samdhyā's zijn de drie overgangstijden van den dag, ochtend, middag en avond (.,de twee samdhyā's” zijn ochtend- en avondschemering) : tevens wordt er mee aangeduid het op die tijdstippen te verrichten ritueel. Hierover handelen b.v. Garuḍa-Pur. 217, 5 vlgg.. Linga Pur. 2, 26, 7. Vgl. ook Tantu Pangg., p. 100 ,.atrisadyabrata", waar echter van badingen $3 \times$ 's daags en $3 \times$ 's nachts sprake is. Zie voorts Goris, Bijdr., p. 20.

toya-snāna, wasschingen (vgl. b.v. Monier Williams, $\mathrm{BH}^{5}$, p. 399); bhasma-snāna is de aanduiding voor het aanbrengen van het bhasma, het secte-kenmerk van asch op het lichaam. Na het baden wrijft men hoofd en deelen van 't lichaam in met asch van den huiselijken haard genomen, onder het opzeggen van een gebedsformule. Een deel van dezen ritus is het aanbrengen van het sectekenmerk op het voorhoofd (pundra); voor Çivaiten bestaat dit uit drie horizontale strepen. Vgl. b.v. Monier Williams, B. H.5. p. 400. Men zie ook Goris, Bijdr., p. 42; Pigeaud, T. P.. p. 275, en Berg. Bijdr. Kon. Inst. 83 (1927). 147 vlgg. voor Java.

-13. lokikācāra, zie beneden. 
-16. udakãnjali, in de hss. CDH: het aanbieden van water; Goris, Bijclr., pp. 35 vlgg.

Çia'āditya; Goris spreekt (Bijdr., p. 3) over de ,vereering van Çiwāditya, dus van Çiwa als Zonne-god”. Over de verbreiding van dezen naam - natuurlijk ook van de gelijkstelling van Çiwa en den Zonnegod - valt ongetwijfeld meer te zeggen. Over het laatste I. Scheftelowitz, Acta Orientalia, 11, 314, die enkele purāṇa-plaatsen citeert voor de vermenging van den Çiva- met den Zonnedienst, ook Mbh. 12, 284, 16. Zie b.v. Saura Pur. 1, 11; Linga Pur. 2, 19, 31 smarāmi devạ̣ ravimaṇ̣̣alasthạ̣ Sadāçivaṇ Çankkaram ādidevam. Men verg. ook Hopkins, Epic Myth. p. 222; Jahn, Saura-Pur., p. 183, s.v. Bhānu; p. 107 n. 3; p. V; Winternitz, Gesch. d. ind. Litt. III, p. 49 (Çiva, Zon, Buddha). Ook in het Mbh. wijzen dus enkele plaatsen op een verbinding van deze twee diensten. Zonnedienst in voor-Indië is oud, niet alleen bij de niet-Arische volkeren, waar ze meer aan den dag treedt, doch ook bij de Hindoes. Secten van zonnevereerders zijn er geweest (Bhandarkar, Vaiṣnavism, Çaivism, etc., $\S \S 114$ vlgg., A. S. Geden, E. R. E., 12, 83). „Some worship the orb of the sun who has just risen as Brahmadeva, the creator, others, the sun on the meridian as Içvara, the destroyer" (Bhandarkar, o.c., p. 152). De naam Çivāditya is ongetwijfeld ook in Voor-Indië: als auteursnaam ontmoeten we het woord wsl. in de XIe E. (vgl. Farquhar, An outline of the religious literature of India, p. 224). Men zie ook (.-J. Bmḍ. Pur. p. 56, 12 vlgg., vooral 20-25 en de aant.; de O.-J. tekst is daar uitvoeriger dan de Sanskrit parallellen.

-18. dodot, bij de voorschriften voor een snātaka (brahmaan, die z'n studietijd heeft voltooid met het nemen van een bad), b.v. Viṣnu 71, 9 sati vibhave na jīrṇamalavadvāsāh syāt; Manu 4, 34.

-19. omah, tegen echtbreuk waarschuwt Manu, 4, 133 vlg. den snātaka, ,,want niets is zoo nadeelig voor een lang leven als dat”. Oudtijds zeer streng gestraft, vgl. Meyer; Wesen d. altind. Rechtsschriften, p. 167 , met noot.

-21. dyūtādi, vgl. b.v. Manu 4, 74 van den gṛhastha: nākṣaih krị̣̣et kadācit, e.a.; vgl. Manu 9, 220 vlgg.

-22. Iokikācāra, vgl. Kats, Sang hy. Kam., p. 149: dīkṣavidhividhānakạ̣, nan dīkṣā awidhiwidhāna: homa widhi, japa, mantra, yoga, dhyāna, pūjāā, brata, tapa, yaça, puṇya, saprakāana, ya lokikācāra ṅaranya.

-26. kriyārcana, nadat de tekst is afgedrukt lijkt het mij juister te lezen: kriyārcana: kriỵã: widhi yoga kunañ. samanikana etc. 
p. 397-4. kṣatriya -- umaritrānâ, vgl. b.v. Viṣṇu 3, 2, waar de eerstgenoemde plicht des konings is : prajāparipālanam, het beschermen van z'n onderdanen: vgl. Manu, 7. 35: 144 kșatriyasya paro dharmah prajānām eva pālanam. Manu 8,$27 ; 28$; Viṣnu 3,65 : hij moet bezit van minderjarigen, behoeftigen, vrouwen beschermen; zie b.v. ook Mbh. 12, 86, 24. Vgl. Vịṇu 3. 17 : beoefenen van liefdadigheid. -5. kalěrika, ,schandivlekken”. Vgl. b.v. Manı 8, 386; 387; 9, 253.

-6. samara, Manu, 7, 87 vlgg., e.a.

danaçüra, vgl. Viṣnụ, 3, 81 vlgg. (landschenkingen aan brahmanen, en andere gaven).

umintuhr'a; bhaktỵ' ', Gautama 11, 19; Manu, 7, 31; 37; 38; Viṣnu 3. 76 e.a.

-8. waicya, vgl. b.v. Manu 1. 90 (zie de Inl.); 9, 326 vlgg.

Çrī : çì, schoonheid, pracht, luister; welvaren, geluk, fortuin, rijkdom; als godin. Fortuna. = Lakṣmī. Bij het volgende: Manu 9, 329: $331: 10.80$.

-11. parachidra: tan parachidra rin para, Goris' afschrift. - Is ya tan te lezen?

-14. gila $\dot{n}^{2}$, vgl. mijn aant. bij Bmc̣. Pur. 119, 26, ald. pp. 285; 366.

-17. cǘra, vgl. b.v. de in de Inl. genoemde teksten; zie ald. p. 373. De zin yatnaha enz. komt in Goris' afschrift niet voor.

-23. maain tan yogya, over de hier volgende bepalingen omtrent huwelijken vergelijke men het in de Inleiding, p. 373 opgemerkte. Evenzoo over de āçrama's, aldaar p. 374.

\section{SLOTOPMERKING.}

Nadat de tekst reeds was vastgesteld ontving ik door de welwillende zorgen van Dr. R. Goris, te Singaradja, Bali, een copie van een handschrift van het Agastyaparwa (Kirtya Liefrinck-Van (ler Tuuk). Deze in de aanteekeningen meermalen genoemde copie is groot 32\% bladzijcle folio. De lezingen sluiten zich veelal aan bij $y$, doch wijken op vele plaatsen belangrijk af van onzen tekst. Moeilijke lezingen zijn vaak door meer eenvoudige vervangen; een aantal passage's bekort, citaten weggelaten. In de aanteekeningen is hiervan vaak melding gemaakt. De ,recensie” die het vertegenwoordigt wekt den indruk verder van het origineel af te staan dan de handschriften $\mathrm{x}$ en $\mathrm{y}$; het manuscript kan evenwel bij de interpretatie goede diensten bewijzen. 


\section{ADDENDA EN CORRIGENDA.}

Tekstcditie, Bïdr. dl. 90.

p. 332, na de $3 \mathrm{e}$ alinea. Door omstandigheden moest de copy van de tekstuitgave worden ingezonden, voordat ik het mij door Dr. R. Goris verschafte handschrift kon benutten. Dientengevolge is daarvan slechts in de aanteekeningen gebruik gemaakt. Mocht mij blijken, dat in andere Balische manuscripten belangrijk materiaal aanwezig is, dan stel ik mij voor, t.z.t., indien ik de beschikking over deze hss. kan krijgen, aanvullingen op de editie, en hopelijk betere lezingen voor bedorven of onbegrijpelijke plaatsen, te geven.

p. 344, 20 i.p.v. <ca>kṣurbhyaṃ 1. <ca>kșurbhyām

p. 350,12 in crit. app. toe te voegen : gun al. : tangun $\mathrm{FH}-$ tru al. : om. $\mathrm{H}$ [Zie de aant.]

p. 350,20 i.p.v. ikań 1 . ikań kadi

p. $352,25 \div$ kan vervallen; verg. glossarium

p. 354,8 i.p.v. unmatah 1. unmattah

p. 356,27 i.p.x. iriya, 1 . iriya.

p. 358,9 de komma achter wighna is gebroken

p. 359,16 i.p.v. janma. 1 . janma :

p. 363,13 i.p.v. kunan sih 1 . kunan si ; in het crit. app. te lezen: si $\mathrm{x}$ : sih $\mathrm{y}$

p. 389,24 i.p.v. $\operatorname{çoụașa~}^{\circ}$ 1. șoḍaça ${ }^{\circ}$

p. 390,8 i.p.v. kṣamayukto 1 . kṣamāyukto

p. 394,23 i.p.x. Așțadaçaparwa 1. Așțādaçaparwa

p. 399 in de Addenda te schrappen p. 358 noot bij r. 6 enz.

p. 405 s.v. taman. Hier te lezen: tama. De „verklaring” vanaf : „Af te leiden” geheel te schrappen!

1. 411 s.v. te lezen Așțādaçaparwa. Zie ook p. 399.

Beschouzingen, Bijdr. dl. 92.

p. 367 boven en n. 1. Ongeveer in den zelfden tijd, waarin ik deze passage schreef, is de in noot 1 bedoelde tekst door Lévi gepubliceerd: Mahā-Karmaribhanga (La grande classification des actes) et Karmavibhangopadeça (discussion sur le Mahā-Karmavibhanga), etc., etc., Paris, Leroux, 1932. Bij deze tekstuitgave aansluitend gaf Krom onlangs een zeer gedetailleerde vergelijking met de „Karmavibhanga-reliefs” op Barabudur (Het Karmavibhangga op Barabuḍur, Med. Kon. Akad. v. Wet., Afd. Lett., 76, B, 8; 1933, pp. 215 vlgg.). In meer dan een punt vertoont deze Boeddhistische tekst overeenkomst met het Agastyaparwa. Men vergelijke (zie Krom's publicatie) aldaar $\S 5,6$ met Ag. pp. 351 vlgg., passim; $\S 7$, de kinderen en grijsaards, met Ag. p. 358, 24; $\$ 15$, de hel, met Ag. p. 351, 4 enz.; $§ 16$ geboorte als dier enz. ook in Ag. volgend, p. $351,23: \S 16$ a en b met Ag. p. 372,$10 ; 23$, ook in volgorde; $\S 55$ met $\mathrm{Ag}$. 353,28 . Wellicht kom ik in ander verband op deze passages uit onzen tekst terug.

\section{Aanteckeningen.}

p. 400 , bii dl. 90 , p. 350 , 3. kadi akșara rüpanya. Pigeaud's Nakṣatrarūpa heeft : kadi akșara bhā: vergelijk den naam Bharaṇī.

bij dl. 90 , p. 350, 7. kĕbroan sanḍan; Pigeaud's Nakṣatrarūpa heeft: kunan ikan̉ sinanguh kĕbon saraṇ̣a. Vgl. Pigeaud, p. 292, n. 73. Goris' hs. heeft: kbon saṇdan.

bij d1. 90, p. 350, 8 Hasta, door mij gelezen i.p.v. sata (ook Goris' ms.), ook in Pigeaud's Nakṣatrarūpa. 
p. 401, bij de noot op dl. 90 , p. 350, 12. Men leze in den tekst, met het hs. van Goris: kunan ikan wintan tangunan hru. Verg. ook T. B. G. 65, p. 289, n. 38. - Voor verdere bijzonderheden vergelijke men Pigeaud's artikel.

p. 403, bij de noot op p. 352, 5. Ook in het O.-J. Bhiṣmaparwa, hs. A p. 132, komt (h)eman voor, bet. $\doteqdot$,.behouden, ongedeerd".

p. 412 , bij de noot op p. 358,6 . Eerder te lezen yat anon kita. Het hs. van 1)r. Goris heeft: yan hanon kita in wwan.

p. 421 , bij de noot op dl. 90, p. 366, 14, toe te roegen: Zie ook Abegg, Messias-Glaube, pp. $16 ; 19$.

p. 422 , n. bij p. 367-9. Vanaparva. Uit een brief van Dr. Goris, Singaradja, 3 Jan. 1935: ..Omtrent de Sabhā- en Wanawāsaparwa zị UHGel. medegedeeld, dat het ons tot heden nog niet gelukt is deze in handen te krijgen".

p. 430 , bij de noot op (ll. 90, p. 373,14 . Hs. B heeft $-t \bar{a}$, de andere hss. $-t a,-t \bar{a}$. 